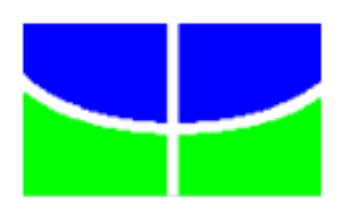

UNIVERSIDADE DE BRASÍLIA

FACULDADE DE AGRONOMIA E MEDICINA

VETERINÁRIA

PROGRAMA DE PÓS-GRADUAÇÃO EM AGRONEGÓCIOS

MILLER GERMÁN SOLARTE GÓMEZ

SISTEMAS DE PRODUÇÃO ORGÂNICA E EM TRANSIÇÃO:

O CASO DOS PRODUTORES RURAIS DAS BACIAS HIDROGRÁFICAS DOS RIOS MARANHÃO E SÃO

BARTOLOMEU - DF

PUBLICAÇÃO: 115/2015 


\section{MILLER GERMÁN SOLARTE GÓMEZ}

\section{SISTEMAS DE PRODUÇÃO ORGÂNICA E EM TRANSIÇÃO: O CASO DOS PRODUTORES RURAIS DAS BACIAS HIDROGRÁFICAS DOS RIOS MARANHÃO E SÃO BARTOLOMEU - DF}

Dissertação apresentada ao curso de Mestrado do Programa de Pós-graduação em Agronegócios, da Faculdade de Agronomia e Medicina Veterinária da Universidade de Brasília (UnB), como requisito parcial para a obtenção do grau de Mestre em Agronegócios.

Orientador: Prof. Dr. José Marcio Carvalho

Coorientador: Prof. Dr. João Paulo Guimarães Soares 
SOLARTE, G. M. G. Sistemas de produção orgânica e em transição: o caso dos produtores rurais das bacias hidrográficas dos rios Maranhão e São Bartolomeu - DF. 2015, 135 f. Dissertação. (Mestrado em Agronegócio) - Faculdade de Agronomia e Medicina Veterinária, Universidade de Brasília, Brasília, 2015.

Documento formal, autorizando reprodução desta dissertação de mestrado para empréstimo ou comercialização, exclusivamente para fins acadêmicos, foi passado pelo autor à Universidade de Brasília e achase arquivado na Secretaria do Programa. O autor reserva para si os outros direitos autorais, de publicação. Nenhuma parte desta dissertação de mestrado pode ser reproduzida sem a autorização por escrito do autor. Citações são estimuladas, desde que citada a fonte.

\section{FICHA CATALOGRÁFICA}

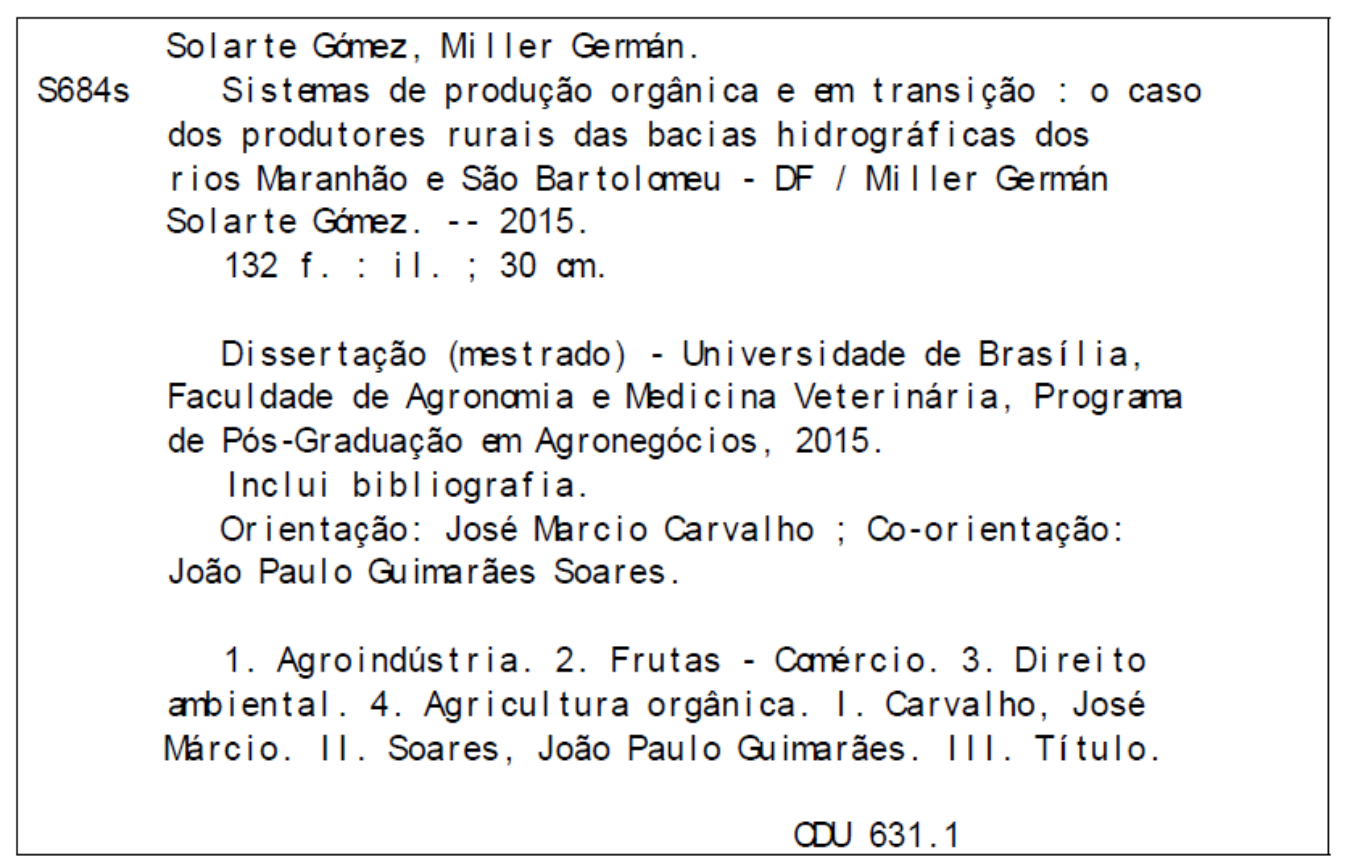




\title{
SISTEMAS DE PRODUÇÃO ORGÂNICA E EM TRANSIÇÃO: O CASO DOS PRODUTORES RURAIS DAS BACIAS HIDROGRÁFICAS DOS RIOS MARANHÃO E SÃO BARTOLOMEU - DF.
}

\begin{abstract}
Dissertação apresentada ao curso de Mestrado do Programa de Pós-graduação Agronegócios da Faculdade de Agronomia e Medicina Veterinária da Universidade de Brasília (UnB), como requisito parcial para a obtenção do grau de Mestre em Agronegócios.
\end{abstract}

Aprovada pela seguinte Banca Examinadora:
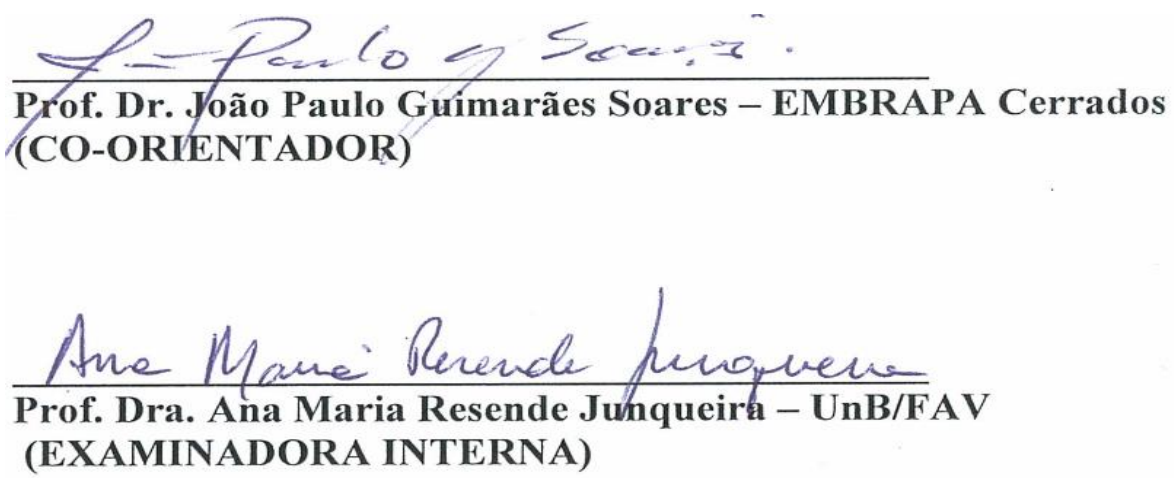

(EXAMINADORA INTERNA)

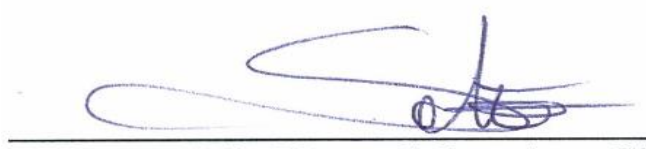

Prof. Dr. Eric Pierre Sabourin - Cirad: Professor Visitante UnB (EXAMINADOR EXTERNO) 
Dedico este trabalho a Deus, toda a gloria é de ele e para ele.

Mãe te dedico minha formatura, você é a melhor das mães do mundo. A meus irmãos Diana e Mauricio, avós Erminia e Salvador, sobrinhos Stefánia, Kevin e Sofia, primos e tios. A meu cunhado Alfredo. À minha princesa linda, por ti e para ti, você é meu mundo, minha inspiração, minha fortaleça, meu pressente e meu futuro. 
Primeiramente quero agradecer a meu Deus por todas as bendições que tem dado à minha vida, por ter-me dado a melhor família motor da minha vida e por quem estou no Brasil lutando por nosso futuro.

Graças mãe, Maria Fanny por estar sempre presente em cada momento da minha vida, e por não ter medido teu esforço para oferecer as melhores condições para que meus irmãos, eu e agora teus netos podamos ter o melhor pressente e futuro. Quero agradecer a meu pai, Tancredo que durante sua vida, sempre me cuidou e aconselhou.

Muito especialmente, agradeço minha namorada, minha parceira, minha companheira, mais que essencial para minha vida e fundamental no meu processo de formação como mestre. Marcela Guzmán, mi princesa linda, nosso amor, união e fé em Deus nos guiarão por sempre em nossa vida.

Agradeço a meu orientador, Dr. José Márcio Carvalho e co-orentador Dr. João Paulo Guimarães Soares, que com seus conselhos e orientações fizeram que o trabalho dissertativo fosse desenvolvido da melhor forma.

Além, agradeço às famílias produtoras que foram avaliadas, em especial a dona Ivone, pela disponibilidade, acolhimento e hospitalidade.

Gostaria ainda de agradecer ao SEBRE, IBRAM, e à EMATER, pelo seu apoio e orientação, fundamental para o desenvolvimento do trabalho dissertativo.

À Capes pela concessão da bolsa de estudo e à Universidade de Brasília pela oportunidade de desenvolver com êxito minha formatura. 


\section{RESUMO}

A presente investigação tem por objetivo contribuir para o entendimento de como os produtores rurais sob sistemas de produção orgânica, alocados nas bacias hidrográficas dos rios Maranhão e São Bartolomeu - DF criam valor nos relacionamentos comerciais com os seus clientes. Avaliaram-se 16 produtores, os quais foram divididos em dois grupos nomeados de A e B. Recebeu a denominação A os produtores rurais com sistemas de produção orgânica, com declaração de produtor orgânico via OCS e com presença ativa no mercado hortifrutícola do DF. Recebeu a denominação B os produtores rurais em transição para produção orgânica, em processo de certificação via OCS e com presença no mercado hortifrutícola do DF. As técnicas para coleta de dados primários incluíram num primeiro momento entrevistas junto aos produtores, e registro de pontos geográficos das propriedades com o objeto de avaliar a adequação à legislação ambiental. Em um segundo momento foram coletados dados a partir de formulários de perguntas para identificar os processos de criação de valor que são utilizados pelos produtores rurais nos relacionamentos comerciais com os seus clientes. Os resultados evidenciaram que o grupo A de produtores rurais apresentou níveis mais avançados de transição agroecológica em relação ao grupo B. Embora o nível de conhecimento dos produtores sobre a legislação ambiental mostrou-se muito baixo para os dois grupos. O total das propriedades (8/8) do grupo A e a maioria das propriedades pertencentes ao grupo B (6/8) encontram-se enquadradas na normativa no que diz respeito as percentual necessário ou mínimo exigido de áreas de RL. No referente ao tamanho das áreas de APP de hidrografia observou-se que o grupo A apresentou déficit; enquanto que para a maioria das propriedades do grupo B (6/8) não aplica este quesito da legislação. Encontrou-se que o caráter associativo e a formação orgânica e ecológica dos produtores pesquisados além de ter contribuído para o redesenho e a conservação da vegetação nativa nas áreas de RL e APP localizadas nas propriedades vem sendo utilizadas como estratégias no processo criação de valor. Adicionalmente, o tipo de governança e a comunicação colaborativa baseada na troca de informações e conhecimentos, também estão contribuindo para o processo de criação de valor.

Palavras-chave: Transição agroecológica, legislação orgânica, legislação ambiental, relacionamentos comerciais, criação de valor econômico. 


\begin{abstract}
This investigation has for its main objective to contribute for the understanding of how rural producers under organic production systems, located in the hydrographic shaving bowl of Maranhão and São Bartolomeu rivers - FD, they create value in the commercial relationships with their clients. 16 producers were evaluated, who were divided into two groups, named A and B. The rural producers with organic production systems, with organic producer declaration via Social Control Organizations (SCO), and with active presence in the DF's fruit and vegetable sector market, received the designation $\mathrm{A}$. The rural producers in transition for the organic production, in certification process via SCO and with presence in the DF's fruit and vegetable sector market received the designation $\mathrm{B}$. The techniques of primary data collection included at first interviews next to the producers, and registration of the geographical locations of the properties in order to evaluate the adequacy to the environmental legislation. Secondly data were collected from question forms to identify the creation processes of value that are used by rural producers in the commercial relationships with their clients. Results evidenced that group A presented more advanced levels of agroecological transition than group B; although the level of producers' knowledge about environmental legislation was shown very low for both of the groups. The total of the properties (8/8) from group A, and most of the properties from group B (6/8) are framed in the normative in which refers regarding to minimal or needed percentage required of areas of Legal Reserve (LR). Relating to the size of Permanent Preservation Areas (PPA) of hydrography it was observed that group A presented deficit; In so far as for most of the properties of group B (6/8) do not apply for this point of the legislation. It was found that the associative character and the organic and ecological formation of the investigated producers, besides of having contributed for the redesign and conservation of native vegetation at the areas of LR and PPA located in the properties; it comes being used as a strategy in the value creation process. In addition, the type of management and the collaborative communication based on the interchange of information and knowledge, it is also contributing for the value creation process.
\end{abstract}

Key Words: Agro ecological transition, organic legislation, environmental legislation, commercial relationships, economic value creation. 


\section{LISTA DE ILUSTRAÇÕES}

Figura 1- Distribuição da área orgânica por região

Figura 2 - Principais cultivos orgânicos permanentes (percentagens respeito do total da área dedicada aos cultivos orgânicos permanentes).

Figura 3 - Participação de produtores com produção orgânica por região no Brasil.

Figura 4- Organismos de avaliação da conformidade no DF. 27

Figura 5 - Estruturas de comercialização do mercado de orgânicos no Brasil. .36

Figura 6 - Cadeia produtiva dos produtos orgânicos.

Figura 7- Divisão e Captura de Valor

Figura 8 - Mapa do Território Rural das Águas Emendadas DF/GO/MG com a localização das bacias hidrográficas dos rios Maranhão e São Bartolomeu - DF.

Figura 9 - Indicação das áreas de reforma agraria e dos perímetros indicados como propriedades.

Figura 10 - Situação fundaria que envolve o acampamento Chapadinha.

Figura 11 - Feições de interesse ambiental no perímetro do acampamento Chapadinha........78

Figura 12 - Feições de interesse ambiental do Perímetro assentamento Pequeno William..... 80

Figura 13 - Feições ambientais de interesse do imóvel $B_{7}$

Figura 14 - Feições ambientais de interesse do imóvel $\mathrm{B}_{8}$. 81

Figura 15 - Díades identificadas entre os grupos de produtores e clientes. 89

Figura 16 - Mecanismo de criação de valor: Construindo Confiança. .....................................96

Figura 17 - Mecanismo de criação de valor: Benefícios mútuos. 98

Figura 18 - Díades identificadas entre os agentes intermediários e os produtores fornecedores de orgânicos. 104 


\section{LISTA DE QUADROS}

Quadro 1 - Organismo avaliador de conformidade por região .26

Quadro 2 - Legislação ambiental no Brasil 30

Quadro 3 - Legislação orgânica no Brasil 32

Quadro 4 - Mecanismos de Certificação no Brasil. .34

Quadro 5 - Formas de Agregar valor. 43

Quadro 6 - Especificidade de ativos nos relacionamentos comerciais.

Quadro 7 - Identificação e descrição da amostra. .55

Quadro 8 - Avaliação quantitativa dos níveis de transição agroecológica em propriedades rurais.

Quadro 9 - Valores atribuídos aos níveis de transição agroecológica. .59

Quadro 10 - Unidades de análise - áreas de preservação permanente - APP, e de reserva legal

- RL, na avaliação da aderência à legislação ambiental.

Quadro 11 - Fases do método de análise de conteúdo. 61

Quadro 12 - Categorias da unidade de análise - Fornecedores. 62

Quadro 13 - Categorias da unidade de análise - Relacionamentos comerciais

Quadro 14 - Marco estrutural do processo de criação de valor no relacionamento comercial Fornecedor - cliente. 64

Quadro 15 - Caracterização dos produtores do Grupo A. 66

Quadro 16 - Caracterização dos produtores do Grupo B. 68

Quadro 17 - Identificação das falências nos indicadores dos sub-níveis 2 e 3 de transição agroecológica para o Grupo B.

Quadro 18 - Identificação das falhas nos indicadores do sub-nível 3 de transição agroecológica para o Grupo A.

Quadro 19 - Elementos de criação de valor presentes na relação comercial fornecedor cliente 
Quadro 20 - Criação de valor no relacionamento grupo de produtores - clientes.

91

Quadro 21 - Elementos de criação de valor presentes na relação comercial mercado cliente produtor fornecedor de orgânicos.

Quadro 22 - Criação de valor no relacionamento mercado cliente - produtores fornecedores. 


\section{LISTA DE TABELAS}

Tabela 1- Valores transição agroecológica grupo A de produtores rurais. 67

Tabela 2 - Valores Transição Agroecológica grupo B de produtores rurais. 69

Tabela 3 - Valores Médios da Transição Agroecológica dos grupos de produtores rurais...... 71

Tabela 4 - Questões sobre legislação ambiental nos dois grupos de produtores avaliados: Grupo A e Grupo B.

Tabela 5 - Quantitativo das áreas de preservação permanente (APP) e de reserva legal (RL) em propriedades rurais pertencentes a dois grupos de produtores orgânicos: Grupo A e Grupo B. 79 


\section{TABELA DE CONTÉUDO}

1. INTRODUÇ̃̃

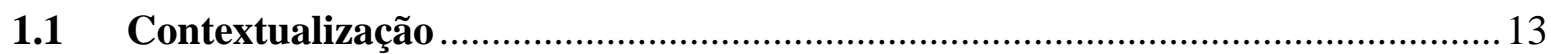

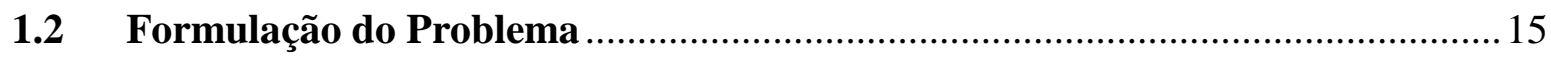

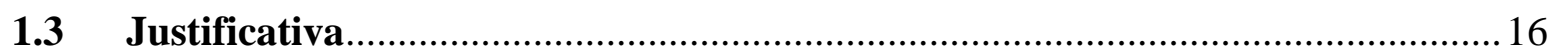

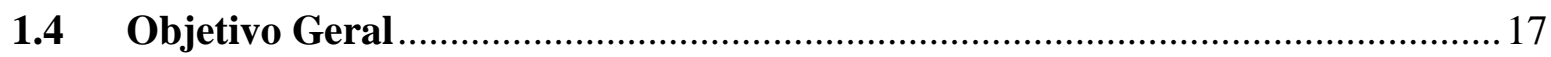

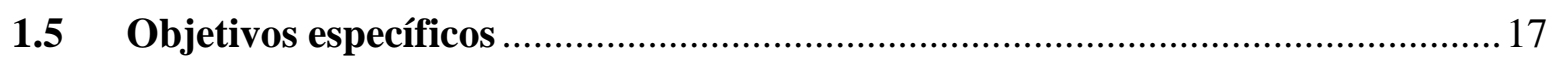

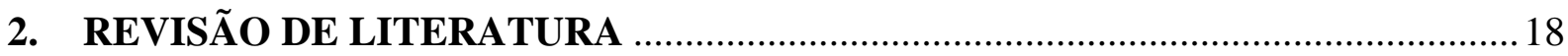

2.1 Agricultura orgânica e transição agroecológica: definições. ............................. 18

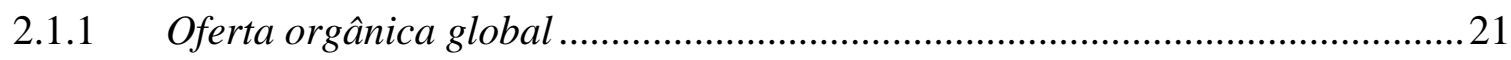

2.1.2 A agricultura orgânica. Contexto Brasileiro ....................................................2 23

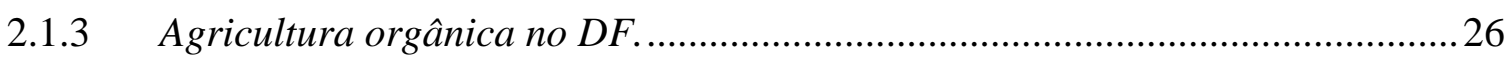

2.1.4 A legislação Ambiental e Orgânica...............................................................28

2.1.4.1 Legislação ambiental no Brasil .................................................................2 29

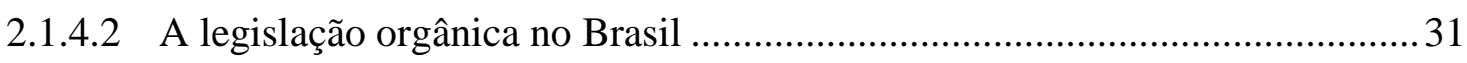

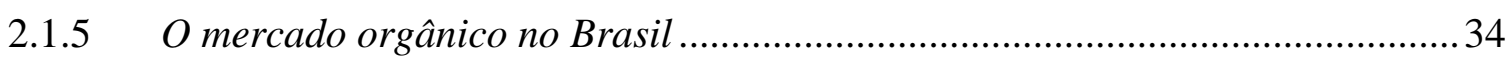

2.1.5.1 O mercado orgânico no DF......................................................................... 37

2.2 A agregação de valor como estratégia de vantagem competitiva no mercado... 39

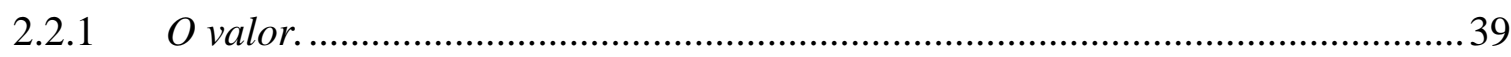

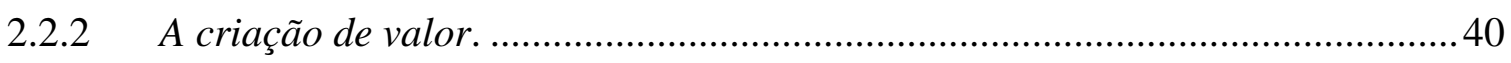

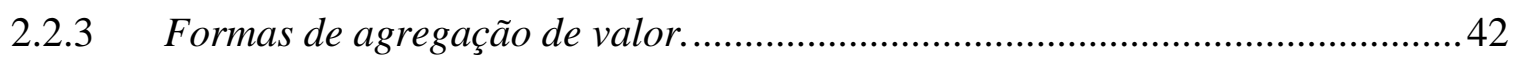

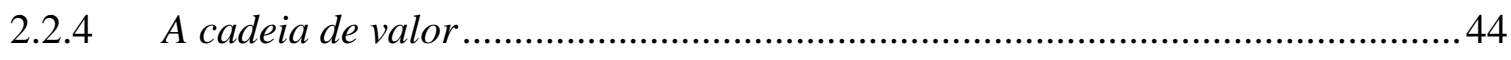

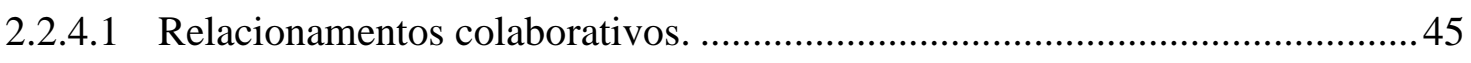

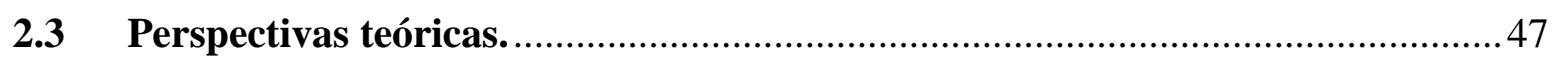

2.3.1 A agregação de valor e a Teoria dos Custos de Transação (TCT). .................... 47

2.3.2 Visão Relacional da Estratégia (Relational View - RV)....................................4 48

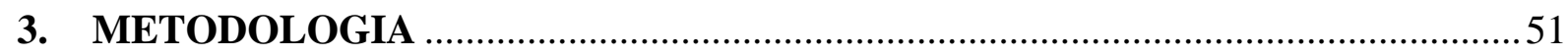

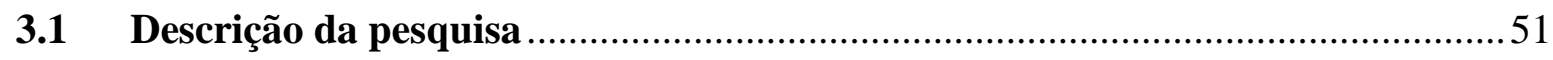

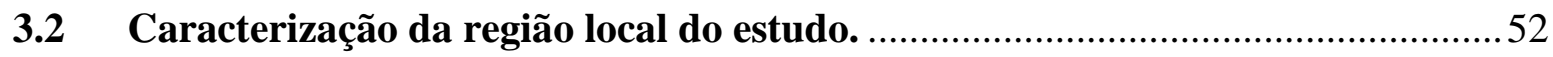

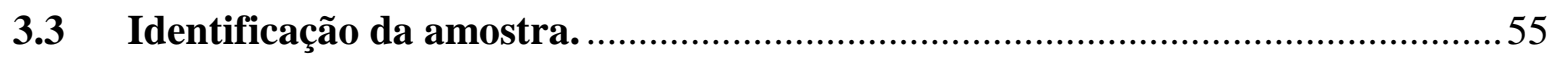

3.4 Produtores Rurais: Adequação à legislação orgânica e ambiental e criação de valor. 57

3.4.1 Avaliação do nível de transição agroecológica. .................................................57

3.4.2 Avaliação da aderência à legislação ambiental ................................................. 60 
3.4.3 Identificação dos mecanismos de criação de valor nos relacionamentos comerciais entre produtores e clientes a partir da adesão à legislação orgânica $e$

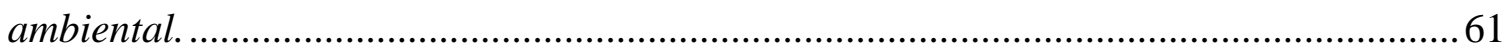

3.5 Percepção dos clientes quanto à criação de valor. .......................................... 65

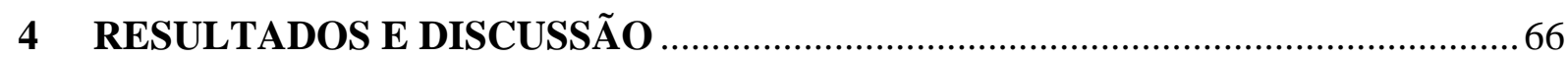

4.1 Produtores Rurais: adequação à legislação orgânica e ambiental e criação de valor. 66

4.1.1 Avaliação do nível de transição agroecológica das propriedades rurais. .........66

4.1.2 Avaliação da aderência à legislação ambiental................................................73

4.2 Percepção dos clientes quanto à criação de valor. ............................................ 98

5 CONCLUSÕES E RECOMENDAÇÕES ............................................................ 111

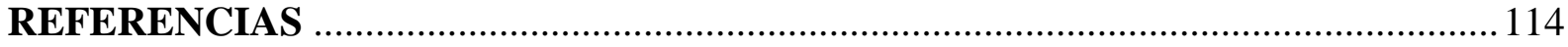

APÊNDICE A - Avaliação da transição agroecológica em propriedades rurais............. 127

APÊNDICE B - Legislação Ambiental....................................................................... 129

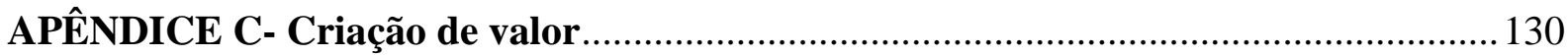




\section{INTRODUÇÃO}

\subsection{Contextualização}

Existe uma grande diversidade de normas e leis ambientais, que tratam da regulamentação e fiscalização das atividades que afetam o ecossistema, tendo-se em conta as leis vigentes. Entretanto, para a legislação de produção orgânica, não existe uma regra geral que possa se aplicar em todas as situações e nem em todo o mundo.

Devido à necessidade crescente no mundo de gerar ações que estimulem a proteção do meio ambiente, foram criados vários acordos internacionais, leis e outros documentos legais, que apresentam aplicações no âmbito nacional ou internacional, sobretudo aqueles relacionados com o uso e a conservação dos recursos naturais e do ambiente em geral. Por outro lado, grande parte da legislação referente à produção orgânica foi aprovada durante os últimos 30 anos como consequência da crescente preocupação com a saúde humana e do planeta (TIERRAMÉRICA, 2001).

Nesse sentido, os sistemas de produção agropecuários hoje apresentam dois tipos de sistemas regulatórios: o primeiro se refere a legislação ambiental, relacionada com o uso e a conservação dos recursos naturais e o ambiente em geral, tendo como aliado à ECOLEX, um serviço de informação relacionada com o direito ambiental - operado em conjunto pela FAO (Organização das Nações Unidas para a Agricultura e a Alimentação), a UICN (União Mundial para a Natureza) e o PNUMA (Programa das Nações Unidas para o Meio Ambiente), que maneja uma base de dados dotada da forma mais completa, tentando unir informação, a disposição dos usuários em todo o mundo (ECOLEX, 2013).

O segundo sistema regulatório é a legislação da produção orgânica, que define as práticas que deverão ser empregadas na produção de alimentos orgânicos (IFOAM, 2013). No entanto, existe no meio científico um confundimento entre Agroecologia e sistemas orgânicos de produção (Figueiredo e Soares, 2012). O sistema orgânico se enquadra no contexto da agroecología. Portanto, nos sistemas orgânicos todas as práticas e processos previstos pela ciência agroecologia podem e devem ser aplicados (Figueiredo e Soares, 2012), desde que em conformidade com a legislação produção orgânica (Brasil, 2011). Neste sentido o processo de transição agroecológico tem sido aplicado aos produtores que tem a necessidade de fazer a conversão para os sistemas orgânicos de produção, utilizando-se os estágios que devem ser 
ultrapassados. Iniciando com agricultura convencional, substituição de insumos, agricultura orgânica, bidiversificação e redesenho dos sistemas de produção (Embrapa 2006).

Embora a Federação Internacional dos Movimentos da Agricultura Orgânica (International Federation of the Organic Agriculture Movement, IFOAM), seja encarregada de harmonizar os conceitos e estabelecer padrões básicos da agricultura orgânica; existe um grande número de normas orgânicas no mundo, algumas das quais são governamentais, outras são normativas de caráter privado, algumas são muito especificas para cada região. No comércio feito entre sistemas baseados em normas distintas requerendo que estes sistemas tenham um reconhecimento e aceitação entre si torna-se complexo entre a diversidade de países e de diferentes culturas e regiões.

Para o caso específico do Brasil, tendo em conta a importância do cuidado com o meio ambiente, o Governo Federal, por meio da Câmara dos Deputados examinou e aprovou durante as últimas décadas uma serie de instrumentos legais, com o fim de contribuir à diminuição dos impactos causados pelo homem ao meio ambiente (CÂMARA DOS DEPUTADOS, 2010); no entanto, este tipo de legislação se torna complexa, pois inclui uma ampla quantidade de leis, resoluções, decretos, e instruções normativas, as quais se encontram em permanente alteração e que compõe entre eles o código Florestal brasileiro (Brasil, 2012).

Da mesma forma, o MAPA, desde o ano 1994 iniciou ações para estabelecer as normas para a produção orgânica no território brasileiro (REBELATTO, 2005), e desta forma conseguir a possibilidade de aplicar a fiscalização no mercado interno e para a exportação, sendo que apartir de 1 de janeiro de 2011 iniciou-se a fiscalização da produção orgânica no Brasil, com base na Lei 10831 e IN 46 (FIGUEIREDO; SOARES, 2012).

O mercado para os produtos orgânicos mantem uma tendência de crescimento, especialmente no Brasil, isto porque a população tem demonstrado cada vez mais preocupação com a saúde e com o meio ambiente (HONDA, 2012). De acordo com o Sebrae (2010), o mercado Brasileiro de produtos orgânicos é caracterizado por manter uma expressiva participação de pequenos e médios produtores, que utilizam dois principais canais para a comercialização dos produtos orgânicos: a venda direta ao consumidor final e a venda para agentes intermediários (varejistas; Empresa de food servisse; mercados institucionais; atacadistas; e empresas no exterior).

Levando em conta a importância que tem ganhado o mercado de produtos orgânicos no Brasil, é importante identificar e elucidar as estratégias de agregação de valor aplicadas à produção por parte dos produtores, e entender como essas estratégias, quando aplicadas à produção, geram valor tanto para o produtor como para o consumidor. Estratégias que gerem 
valor permitem atender as necessidades geradas no mercado consumidor de produtos orgânicos, que atualmente podem ser caracterizados como exigentes e informados. Este novo público pode ser percebido como capaz de gerar novos espaços mercadológicos para o produtor rural (VILCKAS; NANTES, 2007). Neste sentido, Mior (2007) expõe que a utilização por parte dos produtores de seus próprios recursos como a força de trabalho, processos artesanais e produção em pequena escala; e o uso do saber enraizado na cultura regional, são dois aspetos indispensáveis no momento de se referir à agregação de valor na produção rural.

Quando complementados os aspetos produtivos com a adequação às legislações orgânicas e ambientais, poderiam conformar estratégias mercadológicas, que concebidas dentro dos relacionamentos comerciais entre os produtores e os clientes, gerarão a possibilidade de criar valor o qual será identificado no aumento da disposição a pagar pelos produtos, por parte do cliente e na redução do custo de oportunidade pelo produtor (BRANDENBURGER; STUART, 1996). Neste sentido, Agne e Waquil (2011) reconhecem que a forma de produção agroecológica é uma resposta para o cliente que tem a preocupação com o cuidado ao meio ambiente. Daí a importância de aprofundar as discussões acerca dos processos de agregação de valor por meio dos relacionamentos comerciais, em especial quando referidos ao mercado de produtos orgânicos.

O presente estudo, além da introdução, compreende quatro capítulos. O segundo traz a revisão de literatura. No terceiro capitulo são apresentadas as diferentes metodologias utilizadas. O quarto capitulo traz os resultados e sua análise. No quinto capitulo são apresentadas as conclusões assim como as recomendações para trabalhos futuros.

\subsection{Formulação do Problema}

Como já exposto, o mercado dos produtos orgânicos tem apresentado um constante crescimento e junto com ele também se tem evidenciado um notável crescimento da quantidade de supermercados e lojas especializada que ofertam este tipo de produtos (ABRAS, 2011). Segundo o Proargex (2010), no Brasil do total de produtos classificados como orgânicos, aproximadamente o $70 \%$ são comercializados nos supermercados com marcas especificas. Mas existem também outros canais de comercialização de relevância, como as feiras, as cestas entregues em domicílio e as Compras Públicas Sustentáveis (CPS). 
Com um mercado tão amplo, os produtores praticantes da agricultura orgânica, podem desenvolver estratégias que permitam agregar valor aos seus produtos e conseguir um espaço neste segmento mercadológico contribuindo com a inserção e permanência dos produtores orgânicos em novos mercados (VILCKAS; NANTES, 2007). Segundo Mior (2007), neste caso as estratégias de competitividade dos produtores rurais deverão ser pensadas partindo do fortalecimento das atividades próprias dos sistemas agrícolas e também das não agrícolas.

É assim como o princípio orgânico de produção que envolve tanto uma produção baseada na ausência de produtos sintéticos, quanto na minimização de repercussões no meio ambiente, pode se constituir como vantagem competitiva através de estratégias de criação de valor. Com base nas argumentações expostas anteriormente, foi construído o pressuposto direcionador do presente estudo, considerando: As propriedades rurais conduzidas sob sistemas de produção orgânica, alocados nas bacias hidrográficas dos rios Maranhão e São Bartolomeu - DF, evidenciam uma maior disposição a se enquadrar na legislação orgânica e ambiental, e a utilizar esta característica como ferramenta para criar valor nos relacionamentos comerciais produtor - cliente visando obter vantagens competitivas no mercado.

\subsection{Justificativa}

Entre as estratégias de gestão focadas no aumento da competitividade do setor rural, Vilckas e Nantes (2007) destacam a agregação de valor através da diferenciação dos produtos. Uma destas estratégias que na atualidade está tendo sucesso é a implantação de sistemas de produção orgânica, por meio dos quais são obtidos alimentos naturais sem resíduos de agroquímicos. Ainda que a produção orgânica apresente uma tendência crescente, é escassa a produção cientifica que faça uma caracterização dos produtores que acolheram aquele sistema produtivo. Tem-se que estes produtores são enquadrados num grupo homogêneo, assumindo que pelo fato deles conduzir sistemas orgânicos de produção, estão cumprindo com a legislação tanto orgânica como ambiental. Nesse contexto, a pesquisa justifica-se num primeiro momento, pela necessidade de trazer um pouco mais de detalhes a respeito deste grupo de produtores e de verificar se de fato eles conhecem a legislação pertinente e estão aderentes a ela.

Por outra parte, destaca-se que os produtores orgânicos, ao apresentar características diferenciadas, adotam processos de criação de valor diferentes dos produtores convencionais. Ainda que exista uma grande disponibilidade de recursos teóricos que contribuem ao 
entendimento dos processos de agregação de valor em relacionamentos comerciais entre empresas fornecedoras e clientes focados em diversos setores da economia brasileira (FERNANDEZ, 2013), vale a pena salientar o baixo número de estudos que esclareçam por meio de uma análise mais cuidadosa, como acontece a criação de valor nas relações comerciais entre os produtores orgânicos e os seus clientes. Isto ajuda a trazer mais relevância ao desenvolvimento da pesquisa.

\subsection{Objetivo Geral}

Identificar as estratégias adotadas por produtores rurais pertencentes aos sistemas de produção orgânica ou em transição, para criar valor nos relacionamentos comerciais com os clientes.

\subsection{Objetivos específicos}

Verificar nas bacias hidrográficas dos rios Maranhão e São Bartolomeu, no DF, quais as propriedades que são classificadas como de produção orgânica e quais estão em transição; conforme Lei 10831 e IN 46 (Brasil, 2003; 2011);

Identificar o nível de aderência à legislação ambiental dos empreendimentos agrícolas pertencentes a essa região, em relação às áreas de reserva legal - RL e áreas de preservação permanente - APP tendo como referencia o Novo Código florestal, Lei $\mathrm{N}^{\mathrm{O}}$ 12.651 de 25 de maio de 2012 (Brasil, 2012);

Caracterizar as estratégias de criação de valor adotadas pelos produtores rurais para os diferentes tipos de clientes;

Identificar e elucidar os mecanismos de criação de valor presentes nos relacionamentos comerciais entre os produtores de orgânicos e clientes, segundo a percepção do produtor e a percepção do mercado cliente. 


\section{REVISÃO DE LITERATURA}

\subsection{Agricultura orgânica e transição agroecológica: definições.}

No inicio dos anos vinte, forma gestados os primeiros movimentos oficiais que visaram o desenvolvimento de um tipo de agricultura alternativa à convencional, tendo como uns dos princípios a conservação e proteção do meio ambiente e o reaproveitamento de recursos internos da propriedade (DE AQUINO; DE ASSIS, 2005). A agricultura orgânica é consequência de um desses movimentos, tendo crescido de importância ao longo do tempo (DE AQUINO; DE ASSIS, 2005).

De Jesus (2005) relata que uma das primeiras abordagens da agricultura orgânica foi proposta por Sir Albert Howard, conhecido como o pai moderno da agricultura orgânica e quem ressaltou que "A saúde do solo, planta, animal e o homem é uma e indivisível". De Jesus (2005) salienta a critica de Howard na obra "An agricultural testament" (HOWARD, 1943) em relação aos métodos de produção convencional, trabalho que teve repercussões em diversos países, como a Inglaterra onde foi fundada a Soil Association, uma das primeiras instituições que apoiaram a produção agrícola orgânica, a qual hoje em dia é a mais importante entidade inglesa no que tange à difusão, organização, padronização, certificação e apoio à agricultura orgânica (DE JESUS, E. L, 2005).

O trabalho de Howart também teve repercussões nos Estados Unidos, onde nos anos quarenta Jerome Irving Rodale fundou uma editora que publicava várias revistas e muitos livros, sobre a saúde e bem-estar gerado a partir do consumo de alimentos orgânicos. Além de difundir o termo "orgânico" para significar os produtos agrícolas cultivados sem pesticidas; Rodale também fundou o Rodale Instititute, que até hoje desenvolve pesquisa, extensão e formação em agricultura orgânica (IFOAM, 2014a).

Devido ao crescimento da produção agrícola orgânica, além da sua da popularidade, no ano de 1972, a agricultura orgânica foi institucionalizada, com a criação da Federação

Internacional dos movimentos de agricultura orgânica ou "International Federation of Organic Agriculture Movements” (IFOAM), entidade encarregada de adotar uma posição única como a organização internacional do mundo orgânico, unindo as partes interessadas de todas as facetas do setor, para criar uma voz comum sobre questões orgânicas (IFOAM, 2014b). Desde Setembro de 2005, na Austrália a Assembleia Geral da IFOAM, aprovou a moção para estabelecer uma definição concreta e clara da chamada agricultura orgânica, a 
qual elucidasse o que é a agricultura orgânica refletindo sua verdadeira natureza e seus princípios. Perto ao ano 2008, o grupo de trabalho sobre a definiç̧ão da agricultura orgânica da IFOAM obteve a seguinte definição:

[...] a agricultura orgânica é um sistema de produção que mantém a saúde dos solos, os ecossistemas e das pessoas. Baseia-se em processos ecológicos, manutenção da biodiversidade e o uso dos ciclos naturais das condições locais, em lugar da utilização de insumos com efeitos adversos. A agricultura orgânica combina a tradição, a inovação e a ciência em pro do meio ambiente compartindo e promovendo as relações justas e uma boa qualidade de vida para todos os envolvidos (IFOAM, 2008).

A comissão do Codex Alimentarius (2005), encarregada de executar o programa sobre normativas alimentares internacionais como o objetivo de proteger a saúde dos consumidores e assegurar praticas equitativas na comercialização de alimentos, refere-se à agricultura orgânica como:

[...] um sistema holístico de gestão da produção que fomenta e melhora a saúde do agro ecossistema e em particular a biodiversidade os ciclos biológicos e a atividade do solo (CODEX ALIMENTARIUS, 2005 p.3).

No Brasil, de acordo com o descrito no artigo $2^{\circ}$ da Lei $\mathrm{N}^{\circ} 10831$ de 23 de dezembro de 2003, produto orgânico, seja ele em natura ou processado, é aquele que é obtido num sistema de produção orgânico agropecuário ou extrativista sustentável e que não ocasione dano algum ao ecossistema local (BRASIL, 2003).

Como exposto, existe tanta variedade de definições do que é agricultura orgânica, como variadas são as instituições ou autores que abordaram esta temática; destacando-se uma evolução do conceito ao longo do tempo, que passou de uma definição baseada na ausência de produtos sintéticos, a uma visão integral que inclui suas repercussões no meio ambiente, nos recursos naturais, no fator social, e na vida mesma.

Já a agroecologia, é um termo que de acordo com Moreira (2012) vem sendo confundido com a agricultura orgânica e por isso é importante diferenciar ambos os termos. Neste sentido Altieri e Nicholls (2003) resgatam que o principal objetivo dos sistemas conduzidos sob praticas agroecológicas consiste na integração de componentes que gerem um incremento na eficiência biológica global, preservação da biodiversidade e que a produtividade do agroecosistema e sua sustentabilidade sejam mantidas. 
Anos mais tarde, Machado et. al. (2008) descrevem a agroecologia como o estudo das atividades e das interações do saber dos produtores locais, da biodiversidade funcional da região, dos recursos naturais e dos agroecossistemas. Este processo interativo inclui um tempo de conversão que é denominado como de transição agroecológica, que de acordo com Moreira (2003) é a implementação dos processos que conduzam à transição dos sistemas agrícolas convencionais para sistemas de produção alternativos que com o trânsito do tempo adotam uma tendência de baixa dependência de insumos e que fortaleçam sua base ecológica. Moreira (2012) propõe uma definição integra e completa do que em realidade é o processo de transição agroecológica, definindo-o como:

[...] o conjunto de processos sociais, de caráter endógeno e participativo, que refletem a passagem gradativa do atual modelo de exploração socioeconômica da agricultura, para outros que incorporem princípios, métodos e tecnologias de base ecológica que sejam apropriáveis pelos distintos graus de campesinidade e de agroindustrialidade dos agricultores familiares camponeses presentes no território em questão, na medida em que estes seguem um curso de racionalização e diminuição do uso sistemático de agroquímicos na produção e encontrem (novos) circuitos curtos de comercialização de sua produção em transição no nível local. A partir da diminuição da dependência dos agroecossistemas por insumosexternos intensivos em capital, que conflitam com as condições ecológicas dos agroecossistemas, com graus mais elevados de campesinidade, com a saúde dos agricultores e trabalhadores rurais e com as especificidades socioculturais dos agroecossistemas, tal processo de "ecologização" gradativa das práticas agropecuárias (agrícolas, pecuárias e silviculturais) pretende por meio do apoio da extensão rural agroecológica, da pesquisa participativa, de processos educativos e comunicativos permanentes, o estabelecimento de uma rede de experiências produtivas agropecuárias de referência para o manejo agroecológico dos recursos naturais (MOREIRA, 2012).

De acordo com Gliessman (2000), o enfoque agroecológico esta dirigido à aplicação dos princípios e conceitos na ecologia no manejo e desenho de agroecosistemas sustentáveis, gerando novos saberes socioambientais, visando uma transição agroecológica. Gliessman (2000) define o processo de transição agroecológica para agroecosistemas sustentáveis em três níveis fundamentais. O primeiro diz respeito à substituição de técnicas e manejo convencionais por técnicas eficientes de manejo do solo e da agrobiodiversidade. O segundo nível de transição se refere à substituição de inputs e práticas convencionais por práticas alternativas baseadas no melhor uso da biodiversidade funcional como sementes, adubação orgânica e manejo integrado de pragas. Um terceiro nível, mais complexo que os anteriores, é 
conhecido como o redesenho dos agroecosistemas que deverão funcionar com base ao novo conjunto de processos ecológicos que incluam diversificação e integração dos componentes animal/cultivos agrícolas e florestais, visando eliminar as causas daqueles problemas não resolvidos nos dois níveis anteriores.

\subsubsection{Oferta orgânica global}

O mercado dos produtos orgânicos é um dos mais dinâmicos e diversificados, expandindo-se de forma rápida, situação evidenciada no seu grande crescimento mostrado nos últimos anos. Este mercado tinha um valor estimado de US 17,9 bilhões de dólares no ano 2000. Já em 2012 atingiu o valor de US 64 bilhões de dólares (ORGANIC MONITOR, 2014). Em termos de áreas agrícolas sob sistemas de produção orgânica, tem-se que para o ano 1999, houve perto de 11 milhões de hectares dedicadas a este método de produção agrícola, já para o ano 2012 existiram mais de 37,5 milhões de hectares agrícolas orientadas com princípios orgânicos, apresentando um aumento de mais do 240 \% (FIBL; IFOAM, 2014a; FIBL; IFOAM, 2014b). Entre as regiões com maior área agrícola orgânica para o ano 2012, encontram-se a Oceania com 12,2 milhões de hectares, seguida por Europa com 11,2 milhões de hectares; já Latino América, Ásia, América do Norte e a África possuem 6,8 milhões de hectares, 3,2 milhões de hectares, 3 milhões de hectares, e 1,1 milhões de hectares, respectivamente (FIBL; IFOAM, 2014b).

De acordo com a Figura 1, no ano 2012 a Oceania tinha quase um terço do total da área orgânica mundial; Europa, região caracterizada pelo seu crescimento constante de áreas orgânicas mantinha perto do 30 por cento do total da área agrícola orgânica do mundo; seguida pela América Latina com um 18 por cento (FIBL; IFOAM, 2014a; FIBL; IFOAM, 2014b). 
Figura 1- Distribuição da área orgânica por região

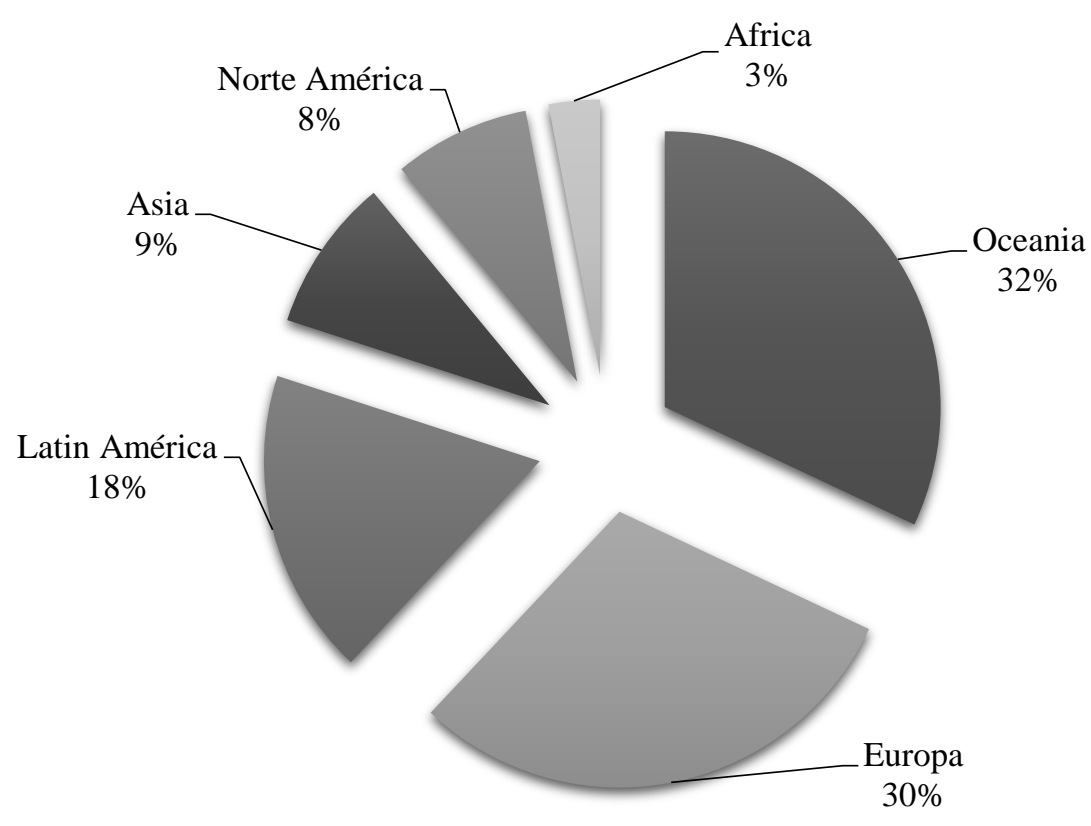

Fonte: Adaptado de FIBL; IFOAM, 2014a; FIBL; IFOAM, $2014 b$.

Em relação à quantidade de área agrícola orgânica por país, encontra-se num primeiro lugar Austrália com 12 milhões de hectares, seguido por Argentina com 4.4 milhões de hectares, em um terceiro lugar China com 1.9 milhões de hectares e num quarto lugar posiciona-se Brasil com 1,8 milhões de hectares (FIBL; IFOAM, 2014a). É importante salientar, que além do incremento das áreas orgânicas, se observa também um aumento de 29 \% no número de produtores orgânicos a nível mundial, assim para o ano 2008 se registraram aproximadamente 1,48 milhões de produtores orgânicos, já para o ano 2012 existiram mais de 1,9 milhões de produtores (SEBRAE, 2010; FIBL; IFOAM, 2014b), distribuídos por regiões, sendo a Ásia a região com maior número de produtores orgânicos (35\% do total de produtores orgânicos no mundo), a África num segundo lugar com $30 \%$ dos produtores, seguida pela Europa com o 17\%, e América Latina com o 16\% (FIBL; IFOAM, 2014a; FIBL; IFOAM, 2014b).

Quanto aos produtos obtidos seguindo os parâmetros da produção orgânica, na Figura 2 são apresentados os principais cultivos permanentes e seu equivalente em percentagem tendo como base uma área total no mundo de 3,2 milhões de hectares de cultivos orgânicos permanentes (FIBL; IFOAM, 2014a; FIBL; IFOAM 2014b). 
Figura 2 - Principais cultivos orgânicos permanentes (percentagens respeito do total da área dedicada aos cultivos orgânicos permanentes).

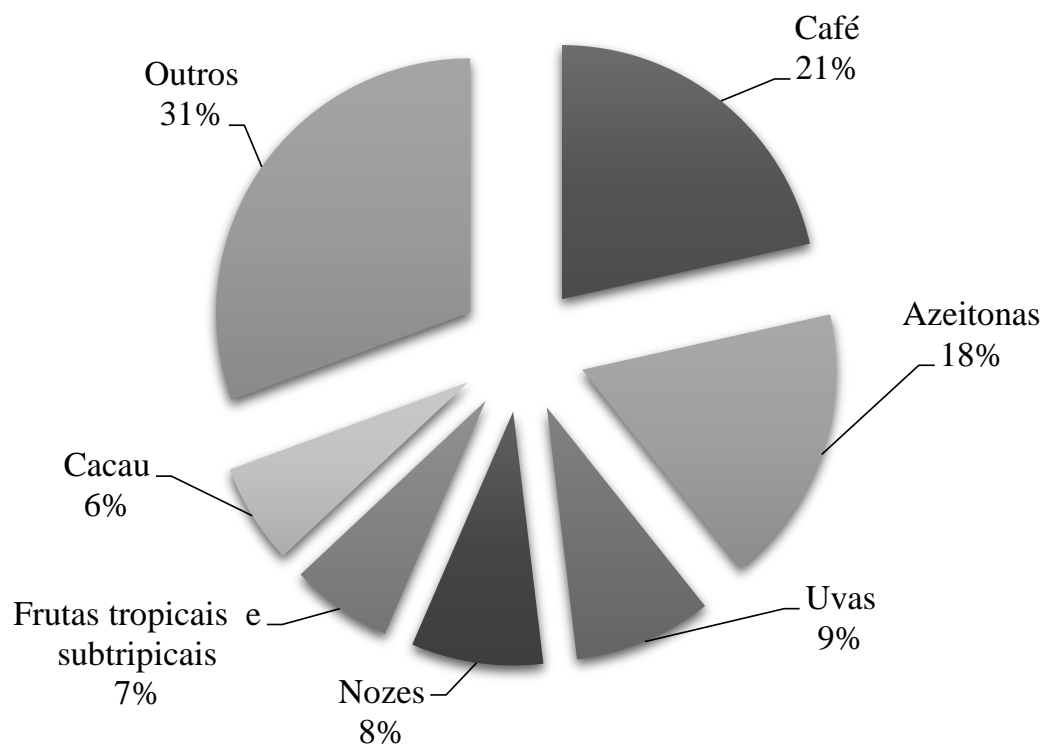

Fonte: adaptado de FIBL; IFOAM (2014a).

Por ordem de importância (Figura 2) encontram-se o café com perto de 0,7 milhões de hectares referentes a uma quarta parte das áreas de cultivos orgânicos permanentes, seguido pelas azeitonas com 0,6 milhões de hectares, uvas com 0,3 milhões de hectares, nozes com 0,27 milhões de hectares, as frutas tropicais e subtropicais com 0,2 milhões de hectares, e o cacau com 0,2 milhões de hectares (FIBL; IFOAM, 2014a; FIBL; IFOAM 2014b).

\subsubsection{A agricultura orgânica. Contexto Brasileiro}

De acordo com o Ministério da Agricultura, Pecuária e Abastecimento (MAPA) para o final do ano 2012, o Brasil tinha aproximadamente 5,5 mil produtores que seguiam as diretivas de produção ligados ao sistema produtivo orgânico, incluindo propriedades rurais e estabelecimentos de processamento de orgânicos; já para final do ano 2013 se contava com 6.,7 mil produtores orgânicos e mais de 10.000 unidades de produção orgânica no Brasil, mostrando um aumento no número de produtores de 22\% em comparação com o ano 2012 (MAPA, 2014a; MAPA; 2014b).

A área total do País com certificação orgânica, atualmente representa mais de 1,5 milhão de hectares, de acordo com os dados de produção orgânica do Brasil, divulgados pelo Mapa no mês de Maio no meio da $10^{\mathrm{a}}$ edição da semana de Alimentos Orgânicos (MAPA, 
2014c). Em termos da área orgânica por estados, tem-se que o Matogrosso e o Pará são as de maior quantidade de terra dedicada a este tipo de agricultura com mais de 622.000 e 602.000 ha respectivamente, seguidos por Amapá com 132.000 ha, Rondônia com 36.000 ha, e Bahia com 25.000 há (MAPA, 2012; RABELLO, 2012). Da mesma forma, a quantidade da área de produção orgânica pode ser expressa em termos das regiões fisiográficas do Brasil. para as diferentes regiões fisiográficas do país temos as seguintes configurações:

Região do Norte: encontram-se dois dos estados com maior quantidade de terra dedicada à produção orgânica, o estado de Pará e o estado de Amapá (PROARGEX, 2010). Deve-se ressaltar que faz parte da região a Amazônia, pelo que a zona está ligada à biodiversidade (PROARGEX, 2010). A região norte é a que possui a maior área dedicada à agricultura orgânica com mais de 778.000 há, e dentre seus principais produtos orgânicos se encontram: as hortaliças, as frutas, os grãos, o açaí, a castanha do Brasil, o dendê, o cacau, o guaraná, o cupuaçu e o açúcar (MAPA, 2012).

Região do Nordeste: esta região, com aproximadamente 79,8 mil ha de produção orgânica, conta com as condições favoráveis para a produção orgânica de frutas tropicais, hortaliças, caju e castanha de caju, grãos, e em poucas quantidades são obtidos produtos como o algodão, o café, a açúcar, o dendê entre outros (MAPA, 2012). No interior também tem a maior produção de mel orgânica de Brasil (PROARGEX, 2010; MAPA, 2012).

Região do Centro-oeste: adentro desta região, com uma quantidade de terra próxima às 650.000 ha dedicadas à pratica de produção orgânica, se encontra o Pantanal, que de acordo com PROARGEX (2010) é a maior planície inundada do mundo. Esta região é caracterizada por ter dirigido sua produção orgânica principalmente à obtenção de carne orgânica junto com os campos de gramíneas naturais, além tem produção de laticínios, hortaliças, café, frutas, açúcar, e mel. É também uma região utilizada para o cultivo de grãos orgânicos (PROARGEX, 2010; MAPA, 2012).

Região do Sudeste: nesta região se encontram as maiores metrópoles do país, pelo qual acontece a maior parte do consumo de produtos orgânicos. Nesta zona a agricultura orgânica está crescendo rapidamente como alternativa viável para pequenos e médios agricultores familiares (PROARGEX, 2010). A região conta com 19,16 mil ha de produção orgânica aproximadamente, e dentre seus principais produtos orgânicos encontram-se a produção de hortaliças, café, frutas, lacticínios, aves e ovos, entre outros (MAPA, 2012). No estado de São Paulo destaca-se a produção de suco de laranja, açúcar e frutas desidratadas (PROARGEX, 2010). 
Região Sul: a região conta com 24.800 há gerenciado sob atividades de produção orgânica, tendo como principais produtos orgânicos os de grãos, erva mate, frutas, mel, aves e ovos, e cultivos de uvas (MAPA, 2012).

Em relação ao número de produtores registrados no cadastro nacional de produtores orgânicos do Mapa, o Brasil tem um pouco mais de 6.700 produtores orgânicos cadastrados, sendo a região do Nordeste a que apresenta o maior número de produtores (2.796 produtores cadastrados), seguida pela região do Sul (1.896 produtores cadastrados), a região do Sudeste (1.463 produtores cadastrados), a região do Norte (317 produtores cadastrados), e a região do Centro-Oeste (247 produtores cadastrados) (MAPA, 2014a). No Figura 3 é apresentada a participação de produtores com produção orgânica por região Brasileira de acordo com o cadastro nacional de produtores orgânicos do Mapa (MAPA, 2014a).

\section{Figura 3 - Participação de produtores com produção orgânica por região no Brasil.}

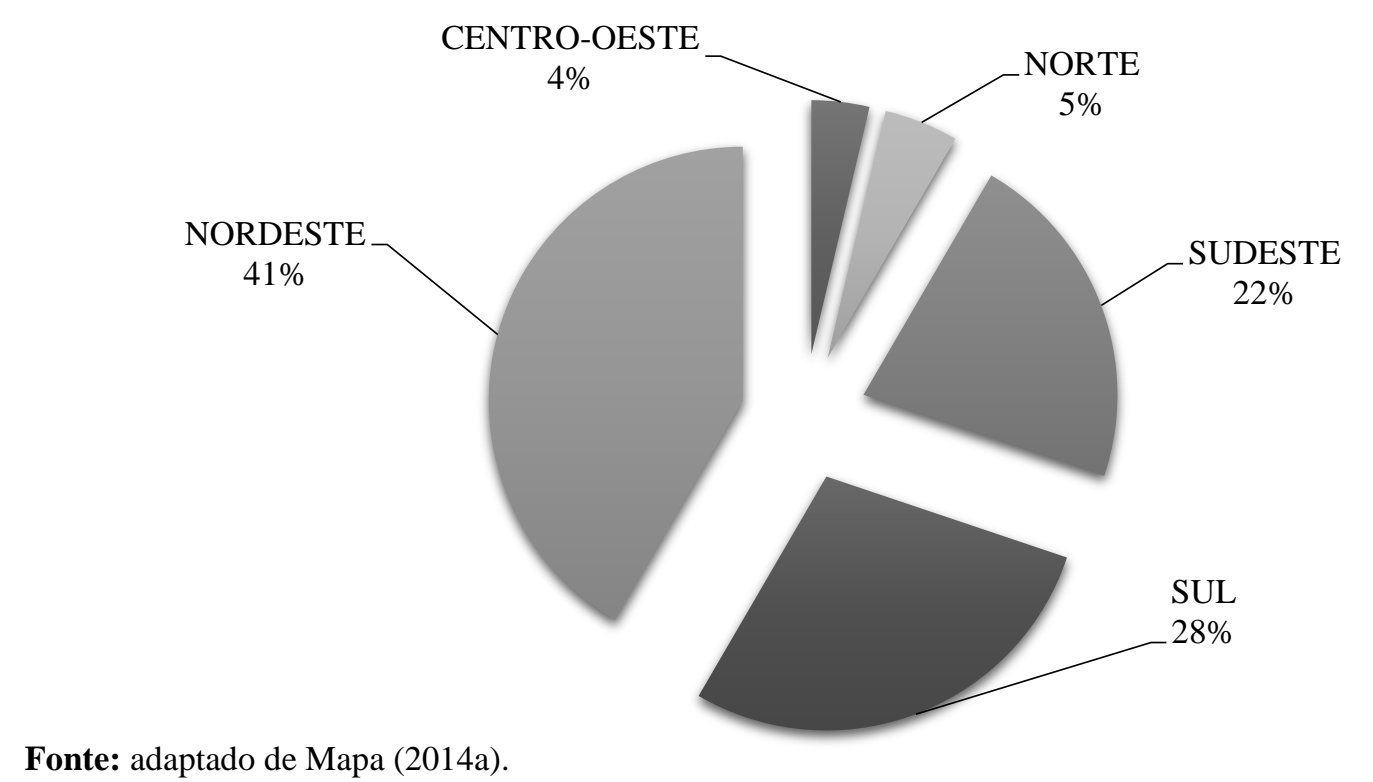

Com toda esta produção orgânica, o Brasil ocupa atualmente uma área expressiva em termos mundiais, o país está posicionado dentre os maiores produtores mundiais de orgânicos, tendo milhões de hectares de vegetação nativa dedicadas à extração sustentável de produtos como o açaí, o látex, frutas e outras espécies próprias da mata tropical, principalmente da Amazônia (PROARGEX, 2010). O número de propriedades conduzidas seguindo princípios orgânicos de produção, também está aumentando de forma significativa, salientando que pelo menos um $80 \%$ dos projetos certificados no Brasil, são gerenciados por agricultores familiares (PROARGEX, 2010). 
Segundo o MAPA (2014d), o número de organismos encarregados da avaliação da conformidade do setor de orgânicos aumento a mais da metade, passando de 79 organizações de Controle Social (OCSs) e 4 Organismos Participativos de Avaliação da Conformidade (OPAC) no ano 2012, para 163 e 11 no ano 2013, respectivamente. Estes números em aumento refletem o crescimento do número de produtores orgânicos no Brasil (MAPA, 2014d). A continuação é apresentado um quadro com a relação entre as regiões que constituem o Brasil e o numero de organismos de avaliação da conformidade da produção orgânica.

\section{Quadro 1 - Organismo avaliador de conformidade por região}

\begin{tabular}{|l|c|c|}
\hline \multicolumn{1}{|c|}{ Região } & Organismo avaliador de conformidade & Quantidade \\
\hline \multirow{2}{*}{ Região Sul } & OPAC & 1 \\
\cline { 2 - 3 } & OCS & 9 \\
\hline \multirow{3}{*}{ Região Sudeste } & OCS & 41 \\
\cline { 2 - 3 } & OPAC & 4 \\
\hline \multirow{2}{*}{ Região Centro-Oeste } & Certificadora por Auditoria & 6 \\
\cline { 2 - 3 } & OCS & 2 \\
\hline \multirow{2}{*}{ Nordeste } & OPAC & 81 \\
\cline { 2 - 3 } & OCS & 14 \\
\hline Norte & OPAC & 4 \\
\hline
\end{tabular}

Fonte: Adaptado de Mapa (2014d).

Pelo exposto, nota-se que a grande maioria de produtores orgânicos Brasileiros está sendo avaliada pelo mecanismo de avaliação da conformidade OCS que por certificação por auditoria, o que tem facilitado a transição de produtores convencionais para um modelo orgânico de produção, pois diminuiu em grande medida a burocracia (MAPA, 2014d).

\subsubsection{Agricultura orgânica no DF.}

De acordo com o cadastro nacional de produtores orgânicos do Mapa, no Brasil existem um total de 10.064 unidades produtivas que implementaram princípios orgânicos de produção, sendo as regiões do Nordeste e do Sul as que concentram a maior quantidade 
(31,78\% e 31,45\% do total das unidades produtivas, respectivamente); seguidas pela Região Sudeste com o 23,9\%, Norte com o 10,16\%, já a região do Centro-Oeste contém 2,7\% das unidades orgânicas produtivas do país, sobressaindo o Distrito Federal e o Matogrosso como os dois estados com maior número destas unidades - 110 unidades produtivas para cada um (MAPA, 2014a).

Da mesma forma o Mapa (2014a) apresenta registros das áreas certificadas destinadas para a agricultura sob os sistemas orgânicos de produção para o DF de 396,6 hectares, incluindo áreas de pastagens. Segundo as cifras do Emater - DF, há 118 unidades de produção em conversão ou preparadas para a certificação (ALMEIDA, 2013).

O DF tem registradas no cadastro nacional de produtores orgânicos do Mapa (MAPA, 2014a), 99 propriedades de produção orgânica que estão sendo acompanhadas por três dos mecanismos de avaliação da conformidade: Certificação por auditoria via Ecocert, um organismo de inspeção e certificação fundado na França em 1991, que se estabeleceu no Brasil desde 2001; Organizações de Controle Social (OCS) sendo quatro as constituídas no DF: Associação de agricultura ecológica (AGE), Associação dos trabalhadores rurais da agricultura familiar da fazenda chapadinha (ASTRAF), Feira do padre e Grupo Agrofloresta; e Organismo Participativos de Avaliação da Conformidade (OPAC) Cerrados. No Figura 4 pode-se observar a relação entre os diferentes organismos de avaliação da conformidade e o total de produtores orgânicos do DF.

Figura 4- Organismos de avaliação da conformidade no DF.

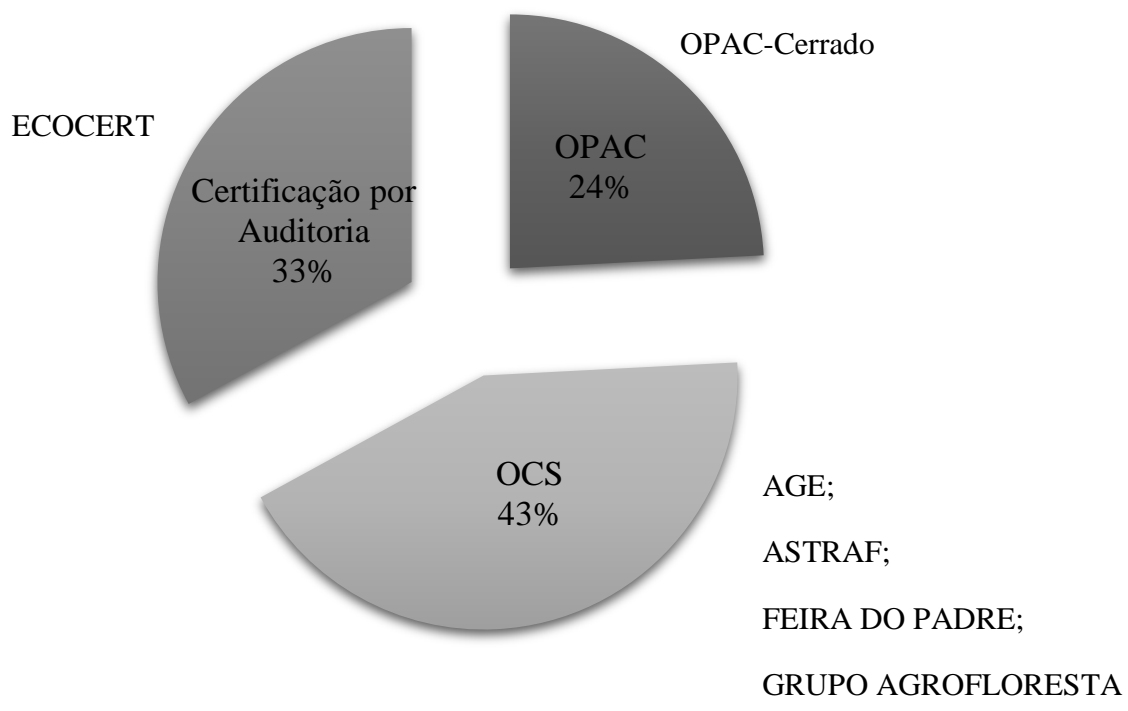

Fonte: Adaptado do Mapa (2014a). 
Na Figura 4 é possível apreciar que os produtores orgânicos do DF seguem a tendência de utilizar em maior número, o controle da produção por meio do mecanismo de avaliação da conformidade OCS, mecanismo que de acordo com Fonseca, et al (2009), surge como alternativa de certificação para os pequenos produtores rurais do Brasil que não tem os recursos técnicos e financeiros para atingir os requisitos da certificação por auditoria.

\subsubsection{A legislação Ambiental e Orgânica.}

Devido à necessidade crescente no mundo de gerar ações que estimulem a proteção do meio ambiente, se tem uma grande quantidade de acordos internacionais, leis e outros documentos legais, que podem ser de aplicação nacional ou internacional, e que estão relacionados com o uso e a conservação dos recursos naturais e o ambiente em geral. Grande parte da legislação referente à produção orgânica foi aprovada durante os últimos 30 anos como consequência da crescente preocupação por o destino de nosso planeta (TIERRAMÉRICA, 2001). Assim, se tem que existe uma grande diversidade de normas e leis ambientais, que tratam da regulamentação e fiscalização das atividades que afetem o ecossistema, tendo em conta as leis vigentes. É importante enfatizar que para a legislação orgânica, não existe uma legislação ambiental geral que poda-se aplicar em todas as situações e nem em todo o mundo.

Neste sentido, a internet tem ganhado grande importância na obtenção de informação referente à legislação ambiental, assim se tem serviços como ECOLEX que é um serviço de informação relacionada com o direto ambiental - operado em conjunto pela FAO (Organização das Nações Unidas para a Agricultura e a Alimentação), a UICN (União Mundial para a Natureza) e o PNUMA (Programa das Nações Unidas para o Meio Ambiente), base de dados dotada da forma mais completa, tentando unir informação, a disposição dos usuários em todo o mundo. A base de dados do ECOLDEX inclui informação sobre tratados, direitos internacionais, documentação para a orientação técnica, legislações nacionais, decisões judiciais, literatura, entre outras. ECOLEX é uma base de dados internacional que oferece informação sobre a legislação ambiental do todo mundo (ECOLEX, 2013).

Uma boa parte dos recursos dessa base de dados é aportada pela FAOLEX da FAO (FAOLEX, 2013). Trata-se de uma completa e atualizada base eletrônica de dados legislativos, leis nacionais e regulações sobre a alimentação, agricultura e os recursos naturais renováveis. Outro recurso importante de informação é o ENTRI, um projeto de colaboração 
internacional com informação sobre tratados e legislações relacionadas com o meio ambiente a nível mundial (TIERRAMÉRICA, 2001). Para a aplicação da norma, existem instrumentos que servem de apoio ao desenvolvimento deste setor, como o Programa do Direito Ambiental do PNUMA (Programa das Nações Unidas para o Meio Ambiente) na América Latina e o Caribe, que oferece assistência técnica e capacitação. Nele podem encontrar-se comparações, assim como informação sobre as leis de cada país (PNUMA, 2013).

Já a legislação orgânica define as práticas empregadas na produção de alimentos tendo em conta normas orgânicas, que por sua vez são constituídas por um conjunto de requisitos que devem ser aplicáveis pelos agricultores, processadores e os comerciantes; assim, qualquer produtor ou operador que pretenda comercializar seus produtos como orgânicos deve, na maioria das vezes, cumprir com pelo menos uma norma de caráter orgânico e tem que ser certificado com esta norma (IFOAM, 2013). No mundo não existe uma normativa comum ou geral que possa ser aplicada às produções que se regem sob práticas agrícolas orgânicas, pois cada país regula de forma independente o mercado dos produtos orgânicos, e a maioria dos países dispõem de legislações básicas. Podem ser citadas como referências importantes: a diretiva 2092/91 da UE, as JAS do Japão, o regulamento NOP dos Estados Unidos (PROARGEX, 2013). Deve ficar claro, no entanto que não existe homogeneidade na legislação.

De acordo com a IFOAM (2013), existe um grande número de normas orgânicas no mundo, algumas das quais são governamentais, outras são normativas de caráter privado, algumas são muito especificas para cada região. No comércio feito entre sistemas baseados em normas distintas requer-se que estes sistemas tenham um reconhecimento e aceitação entre si. A IFOAM tem desenvolvido a família de normas da IFOAM aprovadas oficialmente como orgânicas pelo movimento orgânico internacional, e que de alguma forma traçam um critério para distinguir entre orgânico e não orgânico. A aprovação de cada norma é baseada numa avaliação técnica detalhada destas, seguindo um procedimento determinado pelo sistema de garantia orgânica da IFOAM (2013).

\subsubsection{Legislação ambiental no Brasil}

Tendo em conta a importância do cuidado com o meio ambiente, o Brasil por meio da Câmara dos Deputados examinou e aprovou durante as últimas décadas uma serie de instrumentos legais, com o fim de contribuir à diminuição dos impactos dos impactos 
causados pelo homem ao meio ambiente (CÂMARA DOS DEPUTADOS, 2010). A legislação ambiental no Brasil pode ser tida como bastante extensa, isto faz com que se tenha dificuldade no momento de se encontrar os pontos com maiores implicações, por isso será apresentada a legislação mais relevante através de um quadro resumo (Quadro 2).

\section{Quadro 2 - Legislação ambiental no Brasil}

\begin{tabular}{|c|c|c|c|c|c|}
\hline $\begin{array}{l}\text { LEGISLAÇÃO } \\
\text { AMBIENTAL }\end{array}$ & DESCRIÇÃO & \multicolumn{3}{|c|}{ LEGISLAÇÃO ALTERADA } & $\begin{array}{l}\text { LEGISLAÇÃO } \\
\text { REVOGADA }\end{array}$ \\
\hline \multirow{3}{*}{$\begin{array}{c}\text { NOVO } \\
\text { CÓDIGO } \\
\text { FLORESTAL } \\
\text { LEI N } 12.651 \\
\text { DE } 25 \text { DE } \\
\text { MAIO DE } 2012\end{array}$} & \multirow{3}{*}{$\begin{array}{l}\text { Dispõe sobre a } \\
\text { proteção da } \\
\text { vegetação } \\
\text { nativa e dá } \\
\text { outras } \\
\text { providências. }\end{array}$} & \multicolumn{2}{|c|}{$\begin{array}{l}\text { Lei } \mathrm{N}^{\mathrm{o}} 6.938, \text { de } \\
31 \text { de agosto de } \\
1981 .\end{array}$} & 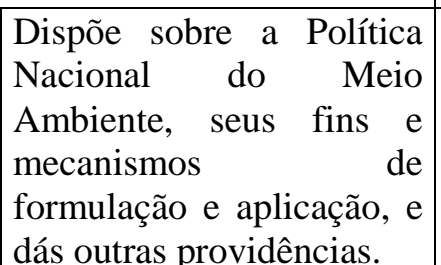 & $\begin{array}{l}\text { Lei } \mathrm{N}^{\circ} 4.771 \text {, de } \\
15 \text { de setembro de } \\
1965 .\end{array}$ \\
\hline & & \multicolumn{2}{|c|}{$\begin{array}{l}\text { Lei } \mathrm{N}^{\circ} 9.393 \text {, de } \\
19 \text { de dezembro } \\
\text { de } 1996 .\end{array}$} & $\begin{array}{l}\text { Dispõe sobre o Imposto } \\
\text { sobre a Propriedade } \\
\text { Territorial Rural - ITR, } \\
\text { sobre pagamento da } \\
\text { dívida representada por } \\
\text { Títulos da dívida Agrária } \\
\text { e dá outras providências. } \\
\end{array}$ & $\begin{array}{l}\text { Lei } \mathrm{N}^{\mathrm{o}} 7.754 \text {, de } \\
14 \text { de abril de } \\
1989 .\end{array}$ \\
\hline & & \multicolumn{2}{|c|}{$\begin{array}{l}\text { Lei } \mathrm{N}^{\mathrm{o}} 11.428 \text {, } \\
\text { de } 22 \text { de } \\
\text { dezembro de } \\
2006 .\end{array}$} & $\begin{array}{l}\text { Dispõe sobre a utilização } \\
\text { e proteção r da } \\
\text { vegetação nativa do } \\
\text { Bioma Mata Atlântica, e } \\
\text { dá outras providências. }\end{array}$ & $\begin{array}{c}\text { Medida } \\
\text { Provisória } \mathrm{N}^{\mathrm{o}} \\
\text { 2.166- } 67, \text { de } 24 \\
\text { de agosto de } \\
2001 .\end{array}$ \\
\hline \multicolumn{3}{|c|}{ LEGISLAÇÃO AMBIENTAL } & \multicolumn{3}{|c|}{ DESCRIÇÃO } \\
\hline \multicolumn{3}{|c|}{$\begin{array}{l}\text { LEI FEDERAL N }{ }^{\circ} 9.605, \mathrm{DE} 12 \mathrm{DE} \\
\text { FEVEREIRO DE } 1988 .\end{array}$} & \multicolumn{3}{|c|}{$\begin{array}{l}\text { Dispõe sobre as sanções penais e administrativas } \\
\text { derivadas de condutas e atividades lesivas ao meio } \\
\text { ambiente, e dá outras providências. }\end{array}$} \\
\hline \multicolumn{3}{|c|}{$\begin{array}{l}\text { RESOLUÇÃO CONAMA No } 237, \text { DE } \\
19 \text { de DEZEMBRO DE } 1997 .\end{array}$} & \multicolumn{3}{|c|}{$\begin{array}{l}\text { Dispõe sobre a revisão e complementação dos } \\
\text { procedimentos e critérios utilizados para o licenciamento } \\
\text { ambiental. }\end{array}$} \\
\hline \multicolumn{3}{|c|}{$\begin{array}{l}\text { RESOLUÇÃO CONAMA No } 303, \text { DE20 } \\
\text { De MARÇO DE } 2002 .\end{array}$} & \multicolumn{3}{|c|}{$\begin{array}{l}\text { Dispõe sobre parâmetros, definições e limites de Áreas de } \\
\text { Preservação Permanente. }\end{array}$} \\
\hline \multicolumn{3}{|c|}{$\begin{array}{l}\text { RESOLUÇÃO CONAMA Nº 369, DE } \\
28 \text { DE MARÇO DE } 2006\end{array}$} & \multicolumn{3}{|c|}{$\begin{array}{l}\text { Dispõe sobre os casos excepcionais, de utilidade pública } \\
\text { interesse social ou baixo impacto ambiental, que } \\
\text { possibilitam a intervenção ou supressão de vegetação em } \\
\text { Área de Preservação Permanente-APP. }\end{array}$} \\
\hline \multicolumn{3}{|c|}{$\begin{array}{l}\text { RESOLUÇÃO CONAMA 387, DE } 27 \\
\text { DE DEZEMBRO DE } 2006\end{array}$} & \multicolumn{3}{|c|}{$\begin{array}{l}\text { Estabelece procedimentos para o Licenciamento } \\
\text { Ambiental de Projetos de Assentamentos de Reforma } \\
\text { Agrária, e dá outras providências. }\end{array}$} \\
\hline \multicolumn{3}{|c|}{$\begin{array}{l}\text { DECRETO FEDERAL No } 6.514, \text { DE } 22 \\
\text { DE JULHO DE } 2008 .\end{array}$} & \multicolumn{3}{|c|}{$\begin{array}{l}\text { Dispõe sobre as infrações e sanções administrativas ao } \\
\text { meio ambiente, estabelece o processo administrativo } \\
\text { federal para apuração destas infrações, e dá outras } \\
\text { providências. }\end{array}$} \\
\hline
\end{tabular}




\begin{tabular}{|c|c|}
\hline LEGISLAÇÃO AMBIENTAL & DESCRIÇÃO \\
\hline $\begin{array}{l}\text { INSTRUÇÃO NORMATIVA (MMA) } \\
\text { No- 3, DE } 8 \text { DE SETEMBRO DE } 2009 .\end{array}$ & $\begin{array}{l}\text { Do plantio e condução de espécies florestais, nativas ou } \\
\text { exóticas; do corte ou a exploração de espécies nativas } \\
\text { plantadas, dos detentores de espécies florestais nativas } \\
\text { plantadas, cadastradas e não cadastraras, da emissão da } \\
\text { autorização para o transporte de produtos e subprodutos } \\
\text { florestais oriundos de espécies nativas plantadas, dos } \\
\text { isentos da apresentação das informações de corte } \\
\text { previstas nesta Instrução Normativa, da autorização de } \\
\text { transporte nos casos previstos e sua validade. }\end{array}$ \\
\hline $\begin{array}{l}\text { INSTRUÇÃO NORMATIVA (MMA) } \\
\text { No- 4, DE } 8 \text { DE SETEMBRO DE } 2009 .\end{array}$ & $\begin{array}{l}\text { Dispõe sobre procedimentos técnicos para a utilização da } \\
\text { vegetação da Reserva Legal sob regime de manejo } \\
\text { florestal sustentável, e dá outras providências. }\end{array}$ \\
\hline $\begin{array}{l}\text { INSTRUÇÃO NORMATIVA (MMA) } \\
\text { No- 5, DE } 8 \text { DE SETEMBRO DE } 2009 .\end{array}$ & $\begin{array}{l}\text { Dispõe sobre os procedimentos metodológicos para } \\
\text { restauração e recuperação das Áreas de Preservação } \\
\text { Permanentes e da Reserva Legal instituídas pela Lei no } \\
4.771 \text {, de } 15 \text { de setembro de } 1965 \text {. }\end{array}$ \\
\hline $\begin{array}{l}\text { DECRETO FEDERAL No } 7.029, \text { DE } 10 \\
\text { DE DEZEMBRO DE } 2009 .\end{array}$ & $\begin{array}{l}\text { Institui o Programa Federal de Apoio à Regularização } \\
\text { Ambiental de Imóveis Rurais, denominado "Programa } \\
\text { Mais Ambiente", e dá outras providências. }\end{array}$ \\
\hline $\begin{array}{l}\text { RESOLUÇÃO CONAMA N }{ }^{\circ} 425, \text { DE } \\
25 \text { DE MAIO DE } 2010 .\end{array}$ & $\begin{array}{l}\text { Dispõe sobre critérios para a caracterização de } \\
\text { atividades e empreendimentos } \\
\text { sustentáveis do agropecuários } \\
\text { rural familiar, e dos povos e comunidades } \\
\text { tradicionais como de interesse social para fins de } \\
\text { produção, intervenção e recuperação de Áreas de } \\
\text { Preservação Permanente e outras de uso limitado. }\end{array}$ \\
\hline $\begin{array}{l}\text { RESOLUÇÃO CONAMA No } 429, \text { DE } \\
28 \text { DE FEVEREIRO DE } 2011\end{array}$ & $\begin{array}{l}\text { Dispõe sobre a metodologia de recuperação das Áreas de } \\
\text { Preservação Permanente - APPs. }\end{array}$ \\
\hline
\end{tabular}

Fonte: Adaptado de BRASIL 1981; 1996; 1997; 1998; 2002; 2006d; 2006f; 2008f; 2009a; 2009b; 2009c; 2009h; 2010k; 2011; 2012.

\subsubsection{A legislação orgânica no Brasil}

O Ministério de Agricultura Brasileiro (MAPA), no ano 1994 começou reuniões para estabelecer as normas para a produção orgânica no território brasileiro, para desta forma conseguir a possibilidade de exportação (REBELATTO, 2005). No ano de 1999 foi criada a normativa $\mathrm{N}^{\circ} 007$ que deu origem ao selo de qualidade para os produtos orgânicos. Esta normativa estabelece os regulamentos da produção, tipificação, processamento, envase, distribuição, identificação e certificação da qualidade para os produtos orgânicos de origem animal ou vegetal tendo em conta a saúde ambiental e humana (BRASIL, 1999). Da mesma forma foram criados os Órgãos Colegiados Nacionais (OCN) e estaduais, com a função de capacitar as instituições certificadoras que serão as responsáveis da certificação e do controle da qualidade orgânica (PROARGEX, 2013). 
No Quadro 3, traçando uma linha de tempo, é apresentada a principal legislação orgânica que regulamenta a produção e comercialização orgânica no Brasil.

\section{Quadro 3 - Legislação orgânica no Brasil}

\begin{tabular}{|c|c|}
\hline $\begin{array}{l}\text { LEGISLAÇÃO } \\
\text { ORGÂNICA }\end{array}$ & DESCRIÇÃO \\
\hline $\begin{array}{l}\text { NORMATIVA } \mathrm{n}^{\circ} 007 \quad \text { DE } \\
1999 .\end{array}$ & $\begin{array}{l}\text { Foi a primeira norma brasileira relacionada com a agricultura } \\
\text { orgânica e, embora tivesse tido algumas alterações continuou } \\
\text { vigente até a entrada em vigor da lei } N^{\circ} 10.831 \text { de } 2003 \text {. } \\
\begin{array}{l}\text { Dispõe sobre normas para a produção de produtos orgânicos } \\
\text { vegetais e animais. }\end{array}\end{array}$ \\
\hline $\begin{array}{l}\text { Lei } \mathrm{n}^{\circ} 10.831 \text {, DE } 23 \text { DE } \\
\text { DEZEMBRO DE } 2003 .\end{array}$ & $\begin{array}{l}\text { Foi regulamentada pelo Decreto Federal } n^{\circ} 6.323 \text {, de } 27 \text { de } \\
\text { dezembro de } 2007 \text {. É o marco legal da agricultura orgânica no } \\
\text { Brasil. A partir desta lei, foram criados os decretos } n^{\circ} 6913 \text {, de } \\
23 \text { de julho de } 2009 \text {, decreto } n^{\circ} 7.048 \text {, de } 23 \text { de dezembro de } \\
2009 \text {, e a instrução normativa IN } 64 \text { do dezembro de } 2008 \text {. } \\
\text { Dispõe sobre a agricultura orgânica, e dá outras providências. }\end{array}$ \\
\hline $\begin{array}{l}\text { PORTARIA } \mathrm{n}^{\circ} 158, \text { DE } 8 \text { DE } \\
\text { JULHO DE } 2004 .\end{array}$ & $\begin{array}{l}\text { Estabelece a criação, composição e funcionamento da } \\
\text { Comissão Nacional da Produção Orgânica (CNPrg) e das } \\
\text { Comissões da Produção Orgânica nas Unidades da Federação } \\
\text { (CPOrg-UF), para assessorar ao Programa de Desenvolvimento } \\
\text { da Agricultura Orgânica (PRO-ORGÂNICO). }\end{array}$ \\
\hline $\begin{array}{l}\text { DECRETO FEDERAL } \\
\text { 6.323, } \mathrm{n}^{\circ} \\
\text { DEZEMBRO DE } 2007 .\end{array}$ & Regulamenta a Lei no 10.831, de 23 de dezembro de 2003. \\
\hline $\begin{array}{l}\text { INSTRUÇÃO NORMATIVA } \\
\mathrm{n}^{\circ} 46, \text { DE } 6 \text { DE OUTUBRO } \\
\text { DE } 2011 .\end{array}$ & $\begin{array}{l}\text { Estabelece o regulamento técnico para os sistemas de produção } \\
\text { animal e vegetal, bem como as listas de substancias permitidas } \\
\text { para uso nos sistemas orgânicos de produção animal e vegetal. }\end{array}$ \\
\hline
\end{tabular}

Fonte: Adaptado de BRASIL 1999; 2003; 2004; 2007; 2008g.

De acordo com o MAPA (2014b), o cultivo e comercialização dos produtos orgânicos no Brasil foram aprovados pela lei 10.831, de 23 de dezembro de 2003. Esta lei incluiu também parâmetros referentes à produção, o armazenamento, a rotulagem, o transporte, a certificação, a comercialização e a fiscalização dos produtos orgânicos. Deve ser salientado que a sua regulamentação, só ocorreu em 2007, com a publicação do Decreto no 6.323 de dezembro do mesmo ano. Este decreto inclui os critérios para o funcionamento de todo o sistema de produção orgânica, desde a propriedade rural até o ponto de venda. 
O decreto cria o Sistema Brasileiro de Avaliação da Conformidade Orgânica, composto pelo Ministério da Agricultura, órgãos de fiscalização dos estados e organismos de avaliação da conformidade orgânica. Esta regulamentação permite a produção paralela, na mesma propriedade, de produtos orgânicos e não orgânicos, sempre que exista uma separação evidente dos processos produtivos, mesmo que autoriza aos agricultores familiares a venda direta ao consumidor, desde que tenham cadastro junto ao órgão fiscalizador (BRASIL, 2007).

Pedroso e Bueno (2010) relataram que o desenvolvimento do mercado de orgânicos relaciona-se de forma direita com a confiança dos consumidores no que se refere à autenticidade dos produtos orgânicos, a qual, segundo os autores, somente pode ser assegurada por meio de programas de certificação eficientes. Estas certificações consistem num conjunto de procedimentos adotados pelas entidades certificadoras que garantem de forma escrita a veracidade de que o produto processo ou serviço segue estritamente as legislações, normas e práticas orgânicas de produção, processamento e comercialização (PEDROSO; BUENO, 2010).

O MAPA (2014e) estabeleceu que para que os produtores possam comercializar seus produtos no Brasil como "Orgânicos", estes devem se regularizar de uma das formas estabelecidas pelo decreto $\mathrm{n}^{\circ} 6.323$ de 2007. Este decreto instituiu o Sistema Brasileiro de Avaliação da Conformidade Orgânica, constituído por os Sistemas Participativos de Garantia da Qualidade Orgânica, além o decreto tem em conta como outro mecanismo de certificação a Certificação por Auditoria; desta forma, qualquer produtor que pretenda comercializar seus produtos como orgânicos devera estar certificado por um Organismo da Avaliação da Conformidade Orgânica (OAC) credenciado junto ao MAPA; ou se organizar em grupo e se cadastrar junto ao MAPA para realizar a venda direta sem certificação. No Quadro 4 são expostos os três mecanismos de certificação orgânica. 


\section{Quadro 4 - Mecanismos de Certificação no Brasil}

\begin{tabular}{|c|c|c|}
\hline MECANISMO & DESCRIÇÃo & IDENTIFICAÇÃO \\
\hline $\begin{array}{l}\text { Controle Social } \\
\text { de Certificação } \\
\text { (OCS) }\end{array}$ & $\begin{array}{l}\text { A organização devera estar cadastrada no MAPA ou em } \\
\text { outro órgão fiscalizador federal, estadual ou distrital } \\
\text { conveniado. Quem dá a garantia da qualidade orgânica é } \\
\text { o produtor, acompanhado de perto pela sociedade. A } \\
\text { garantia se baseia na relação de confiança entre quem } \\
\text { vende e quem compra. Os produtores devem permitir } \\
\text { que seus consumidores visitassem sua propriedade, } \\
\text { assim como também permitem a entrada dos órgãos de } \\
\text { fiscalização, sempre que preciso. É permitida, apenas, a } \\
\text { venda direta de seus produtos ao consumidor, à merenda } \\
\text { escolar (através do Programa Nacional de Alimentação } \\
\text { Escolar - PNAE) ou à CONAB (Programa de Aquisição } \\
\text { de Alimentos - PAA). Os produtores assinam um Termo } \\
\text { de Compromisso, comprometendo-se a atender ao } \\
\text { Decreto No } 6.323 / 07 \text { nos princípios e diretrizes da } \\
\text { produção orgânica. Os produtores ligados às OCS não } \\
\text { podem colocar o selo federal do SisOrg em seus } \\
\text { produtos. }\end{array}$ & $\begin{array}{c}\text { Declaração de } \\
\text { Cadastro de } \\
\text { produção orgânica. }\end{array}$ \\
\hline $\begin{array}{c}\text { Organismos } \\
\text { Participativos de } \\
\text { avaliação da } \\
\text { conformidade } \\
\text { (OPAC) }\end{array}$ & $\begin{array}{l}\text { Estes organismos credenciados pelo MAPA integram o } \\
\text { Sistema Brasileiro de Avaliação da Conformidade } \\
\text { Orgânica - SisOrg. Permite aos produtores certificados o } \\
\text { uso do Selo do SisOrg. Sistemas construídos na } \\
\text { confiança, em redes sociais e no intercambio de } \\
\text { conhecimento. Os produtores poderão efetuar venda } \\
\text { direta a consumidores e venda a indústrias, } \\
\text { processadores, mercados, supermercados, lanchonetes, } \\
\text { restaurantes etc. e, mesmo, exportação. Assim, a } \\
\text { participação no SisOrg permite a venda a terceiros. }\end{array}$ & \\
\hline $\begin{array}{l}\text { Certificação por } \\
\text { auditoria }\end{array}$ & $\begin{array}{l}\text { Pode ser feita por agências locais, internacionais ou por } \\
\text { parcerias entre elas. Têm por obrigação avaliar e } \\
\text { garantir a conformidade da produção orgânica sob sua } \\
\text { responsabilidade. Devem possuir quadro profissional } \\
\text { habilitado e registrados em seus conselhos profissionais } \\
\text { que procederão, respectivamente, com as visitas de } \\
\text { inspeção "in loco" às propriedades e com as análises de } \\
\text { aceitação de certificação. Têm conta leis nacionais, } \\
\text { implica investimento monetário. Permite aos produtores } \\
\text { certificados o uso do Selo do SisOrg nos rótulos de seus } \\
\text { produtos. }\end{array}$ & \\
\hline
\end{tabular}

Fonte: Adaptado de MAPA (2014e); PEDROSO; BUENO (2010).

\subsubsection{O mercado orgânico no Brasil}

Até agora há uma clara indicação de que o mercado dos produtos orgânicos mantêm uma tendência crescente, especialmente no Brasil que de acordo com Honda (2012) é devido em parte ao fato de que a saúde é uma grande preocupação dos Brasileiros. Como resultado 
deste evidente ganho de popularidade os pontos de venda destes produtos tem incrementado, incorporando novos canais de comercialização. Assim, em países como o Brasil, Egito, a China e Kenia, as vendas têm sido conduzidas pelas grandes cadeias de supermercados internacionais e lojas especializadas (KLEDAL, 2009).

No Brasil, por exemplo, as vendas de produtos orgânicos por meio das redes de supermercados chegam até $77 \%$, indicando uma alta concentração neste canal de distribuição em relação com os demais canais (MACENA, 2011). Esta tendência gera um maior número de produtores dispostos a produzir de forma orgânica, tendo-se como consequência uma necessidade, por parte dos produtores, de um mercado definido, de ai que seja importante conhecer as características da cadeia produtiva destes produtos.

De acordo com Ormond et. al. (2002) o produtor é um elo fundamental da cadeia produtiva dos produtos orgânicos, destacando-se que sua entrada neste mercado de produtos orgânicos, muitas vezes é promovida pela diferença no preço quando comparado aos produtos obtidos sob os sistemas de produção convencionais.

De acordo com o Sebrae (2010), o mercado Brasileiro de produtos orgânicos é caracterizado por pequenos produtores e medianos produtores. O processamento já é um elo ocupado principalmente nas grandes empresas, enquanto que o atendimento do mercado nicho é feito pelas pequenas. A entidade ressalta dois canais de comercialização dos produtos orgânicos no Brasil, a venda direta ao consumidor final e a venda para agentes intermediários. Na Figura 5 são apresentadas as estruturas de comercialização mais comuns no mercado de produtos orgânicos no Brasil. 
Figura 5 - Estruturas de comercialização do mercado de orgânicos no Brasil.

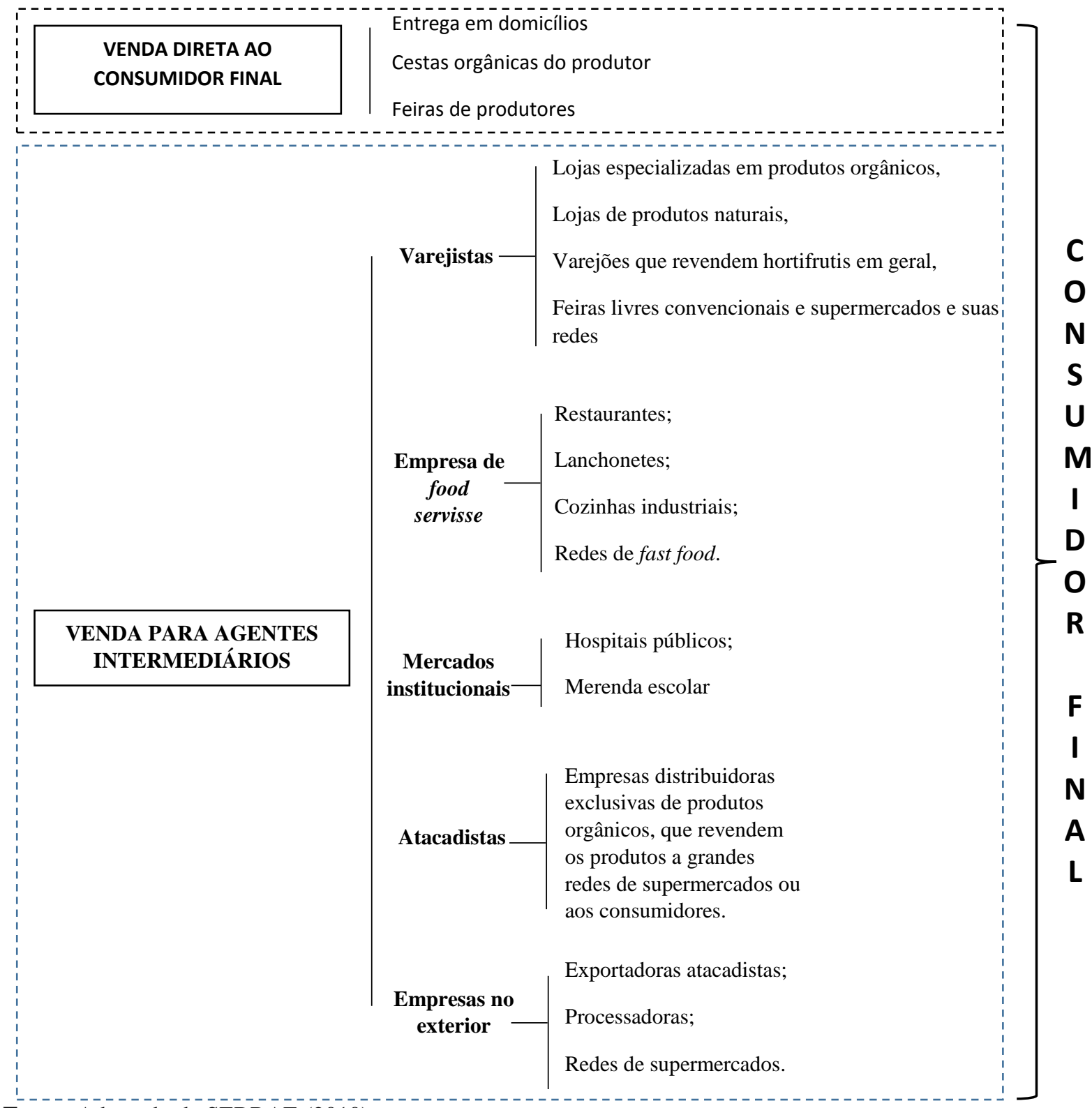

Fonte: Adaptado de SEBRAE (2010).

Quanto que a cadeia produtiva dos orgânicos pouco se diferencia das demais cadeias agroalimentares, de acordo com Ormond et. al. (2002) a única diferença que pode se ressaltar é presença da figura da certificação. Neste sentido o Kledal (2009), reconhece a existência de dois tipos de cadeias de suprimentos nas quais estão inseridos os produtos orgânicos, que tem origem na certificação orgânica tal como se pode apreciar na Figura 6. 
Figura 6 - Cadeia produtiva dos produtos orgânicos.

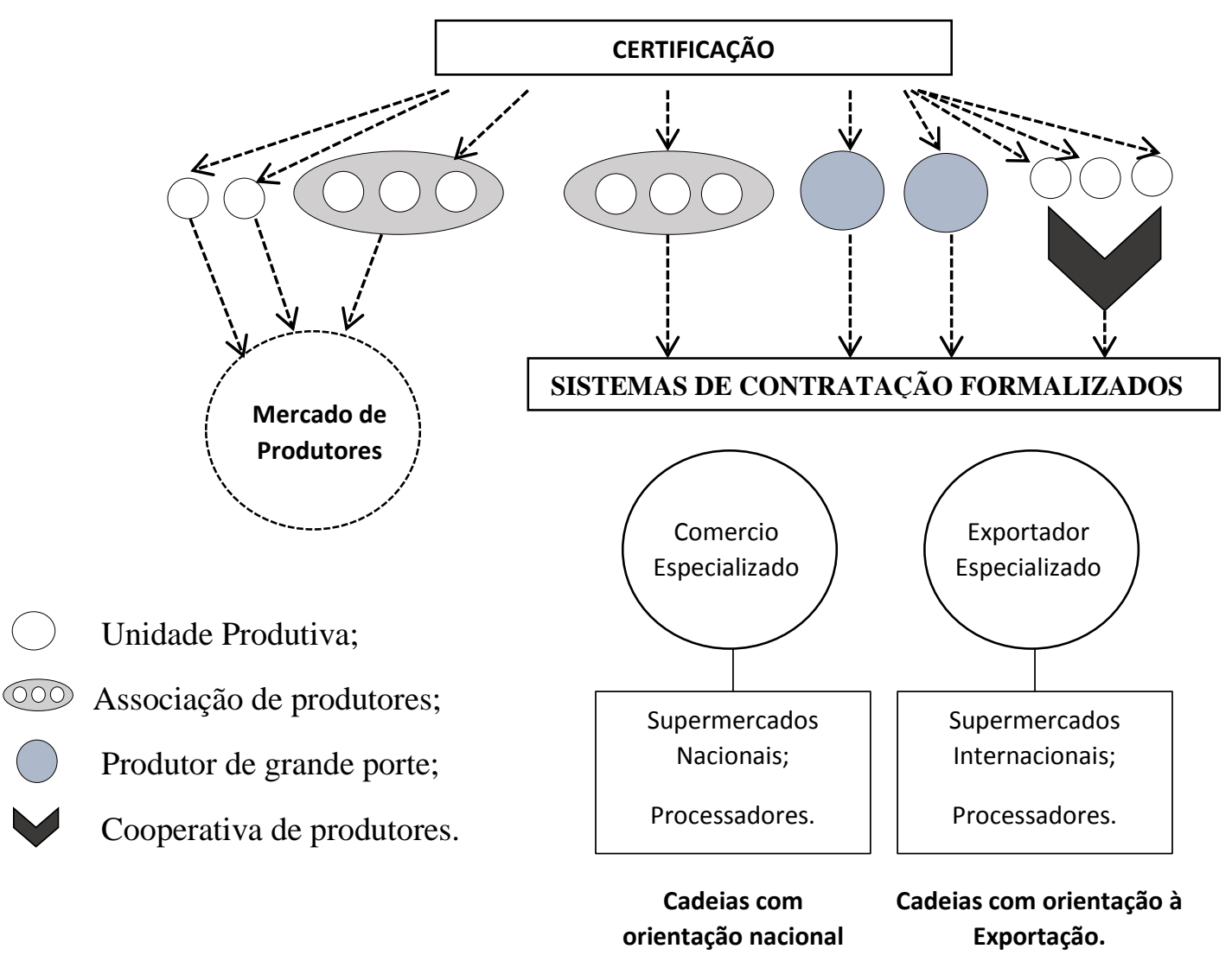

Fonte: Adaptado de ORMOND et. al. (2002); KLEDAL (2009).

De acordo com Kledal (2019), o primeiro sistema é caracterizado por ter uma estrutura curta definida, tem atores do mercado tradicional, mas tem-se um conjunto de regras e regulações aplicadas os mercados e um maior grau de estruturação das relações de mercado (Figura 6). O segundo sistema envolve algum tipo de processamento, com forte percepção de a segurança alimentar, um alto grau de coordenação, um setor de processamento consolidado e produtores organizados (Figura 6). Neste segundo sistema é possível que se tenha também um segmento dedicado a atividades de exportação.

\subsubsection{O mercado orgânico no DF.}

Em relação ao crescimento do mercado de orgânicos, o DF não é estranho a esta realidade, pois de acordo com o Emater - DF (2012 apud ALMEIDA, 2013) o Distrito Federal apresenta taxas de crescimento do mercado de orgânicos de $20 \%$ a.a. e tende a um 
crescimento ainda maior quando se observa que o consumo de frutas e hortaliças orgânicas representa em $1,5 \%$ do total consumido deste tipo de alimentos.

Assim como as vendas de produtos orgânicos no Brasil crescem, também crescem a quantidade de supermercados, de formatos de lojas, além da qualidade dos serviços prestados. Tem se que as vendas no ano 2010 alcançaram cerca de 5\% superior em valor e 7\% em volume, isto quando comparadas com o ano de 2009 (ABRAS, 2011). Têm-se como as principais redes de varejo no Brasil a Companhia Brasileira de Distribuição (Pão de Açúcar), Carrefour Comércio e Indústria Ltda, e Walmart Brasil Ltda; companhias que investiram em marcas próprias e ganharam ampla aceitação e confiança dos consumidores (ABRAS, 2011). Estas grandes redes contam com a escala necessária para oferecer alta qualidade de produtos com preços mais baixos (ABRAS, 2011).

No Brasil, cerca de $70 \%$ dos produtos orgânicos vendidos dentro do país são comercializados nos supermercados os quais já tem marcas especificas, o outro $30 \%$ em mercados médios (PROARGEX, 2010). De acordo com Vilela, et al. (2006), os locais de compra mais utilizados do DF são as feiras (42\%) e as cestas entregues em domicílio (27\%). A participação dos supermercados $(17 \%)$ e da CEASA (Principal feira de comercialização de produtos orgânicos do DF) (14\%) como locais de aquisição de produtos orgânicos ainda é pequena.

Existe mais um canal de comercialização que deve ser destacado, as Compras Publicas Sustentáveis (CPS), que de acordo com Sambuicchi (2014), foi introduzida como opção de venda para a produção agrícola na forma de programas tais como o Programa de Aquisição de Alimentos (PAA), um instrumento de política pública que visa a promoção do desenvolvimento nacional sustentável (BRASIL, 2010k). O programa adquire os alimentos por meio de licitações, tendo como referencia os preços dos mercados orgânicos regionais.

O programa paga até $30 \%$ a mais pelo produto orgânico, em comparação com os produtos convencionais (MDS, 2014). De acordo com a Lei Federal $n^{\circ} 11.947 / 2009$, pelo menos $30 \%$ dos recursos dos municípios, repassados pelo Fundo Nacional de Desenvolvimento da Educação (FNDE) para alimentação escolar, deve ser utilizado para comprar produtos da agricultura familiar e/ou empreendedor familiar rural ou de suas organizações, dando prioridade aos assentamentos de reforma agrária, das comunidades tradicionais indígenas e das comunidades quilombolas (MACENA, 2011).

No DF a maior parte da produção orgânica concentra-se na área de hortaliças, os demais produtos são gerados em escalas menores, tanto em volume como em diversidade (MAGALHÃES, 2004). De acordo com Almeida (2013), a oferta de produtos orgânicos no 
Distrito Federal, inclui produtos produzidos fora, os quais são trazidos de outros estados ou mesmo países, pelas mesmas associações, cooperativas ou supermercados.

\subsection{A agregação de valor como estratégia de vantagem competitiva no mercado.}

No mercado de produtos convencionais é importante analisar as estratégias de agregação de valor aplicadas à produção, tem-se que levar em conta que hoje as empresas estão na procura de vantagens que gerem diferenciação ou de novos mercados; mesmo assim, é importante entender como essas estratégias, quando aplicadas à produção, geram valor tanto para o produtor como para o consumidor. Neste sentido, Silveira e Sousa, (2010), relatam que caracterizar os mecanismos que induzem às empresas na modernização das suas operações de produção pode ter implicações importantes, pois partem destas empresas as iniciativas que visaram à agregação de valor. Assim, se a empresa tem como base a capacidade de agregar mais valor em uma cadeia de produção e consumo pode levá-la a aproveitar novas oportunidades no mercado ou até mesmo criar novos mercados.

O contínuo crescimento do mercado de orgânicos no Brasil, sua relativa estabilização econômica, o aumento da renda do consumidor brasileiro e uma maior preocupação com a qualidade, têm levado ao surgimento de uma demanda não mais preocupada apenas com baixo preço, mas também com qualidade (MESQUITA; LARA; SOUKI, 2010). Estratégias que gerem valor permitem atender estas necessidades e desejos dos consumidores de produtos orgânicos, que hoje são mais exigentes e mais bem informados (VILCKAS; NANTES, 2007). Os referidos autores reconhecem a importância de aprofundar as discussões acerca dos processos de agregação de valor, em especial nos produtos orgânicos.

\subsubsection{O valor.}

De acordo com Fernandes (2013), o conceito do valor é amplamente utilizado em diversas disciplinas e campos do conhecimento. Segundo Porter (1985), o valor tem foco no lucro de determinada empresa, não obstante, Brandenburger e Stuart (1996), traçam uma abordagem mais integrativa da cadeia de valor.

Vilckas e Nantes (2007) definem valor tendo em conta três perspectivas, o preço, o comportamento do consumidor e estratégia. O valor definido desde a perspectiva preço é o trade-off percebido pelo consumidor entre os benefícios que podem ser obtidos e os 
investimentos (monetários e não monetários, enfatizam os autores) feitos para obter aqueles benefícios (VILCKAS; NANTES, 2007). Desde o ponto de vista do comportamento do consumidor, Vlikas e Nantes (2007) definem valor de acordo com a satisfação das necessidades e desejos do consumidor, por parte do produto ou serviço. Já desde a perspectiva estratégica, o valor é referido à disposição a pagar do consumidor, por aquilo que a empresa esteja disposta a oferecer-lhe (VILCKAS; NANTES, 2007).

Num contexto de relações comerciais, Ramsay (2005) define o valor como o a satisfação ou beneficio, que quando associado com a troca de recursos, é percebido ou apreciado pelos consumidores compradores e os comerciantes beneficiados desses recursos. Peteraf e Barney (2003) adotam uma definição mais geral de valor, desde uma visão dirigida ao ganho de vantagem competitiva com base no desenvolvimento de recursos raros e escassos, valiosos e de difícil imitação em relação com outros, desta forma a empresa adota uma concepção atual de criação de valor superior à de um concorrente comum, mantendo sua vantagem competitiva ao longo do tempo.

Segundo uma visão mais ampla, Porter e Kramer (2011) assumem o princípio do valor compartilhado - shared value - implicando a criação de valor econômico e social nas comunidades onde as empresas tem abrangência. Os autores definem o valor compartilhado como as políticas e praticas operacionais que geram um aumento na competitividade de uma empresa, enquanto melhoram as condições sociais e econômicas das comunidades influenciadas.

Brandenburger e Stuart (1996) propuseram um modelo econômico de valor agregado que envolve as vertentes de valor para cliente e valor de relacionamentos. No momento de analisar a criação de valor a partir dos relacionamentos comerciais existentes entre os produtores - fornecedores, os consumidores e mercados clientes, tópico relevante do presente trabalho; foi escolhida a visão de valor interpretada por Brandenburger e Stuart (1996), tendo em conta que o modelo dos autores reconhece a concepção de valor no campo das relações entre as empresas, mediante uma rede vertical, constituída por o consumidor, a empresa e o fornecedor.

\subsubsection{A criação de valor.}

A necessidade de identificar onde devem ser focadas as atividades operacionais de uma organização vem sendo ressaltado por Hill (2000) desde suas primeiras publicações, 
argumento este, baseado no fato de que se os esforços são concentrados em um aspecto das operações, poderia ser aumentada a chance de obter uma vantagem competitiva frente à concorrência. Uma corrente de debate da academia é justamente identificar um padrão para estabelecer qual deve ser o foco deste esforço produtivo ou, em outras palavras, qual deve ser a prioridade competitiva. Neste sentido, Fernandes (2013), após de uma extensa revisão bibliográfica referente à temática de criação de valor, afirma que este tema está relacionado com questões como inovação, empreendedorismo e conhecimento. Contudo, é possível observar que a literatura referente à criação de valor ainda não é generalizada; Lepak, et. al, (2007), ressaltam que o tópico referente à criação de valor e os mecanismos para atrapalhá-lo ainda tem divergências entre os estudiosos do tema.

Brandenburger e Stuart (1996), na busca de delimitar um pouco mais a discussão em relação à criação de valor, definem a criação de valor pela empresa como a diferença entre o custo de oportunidade do fornecedor e disposição a pagar pelo cliente. Na figura que descreve a definição de valor feita pelos autores (Figura 7), pode-se apreciar uma integração ao longo da cadeia que gera a criação de valor por meio dos relacionamentos entre os fornecedores e clientes.

Figura 7- Divisão e Captura de Valor.

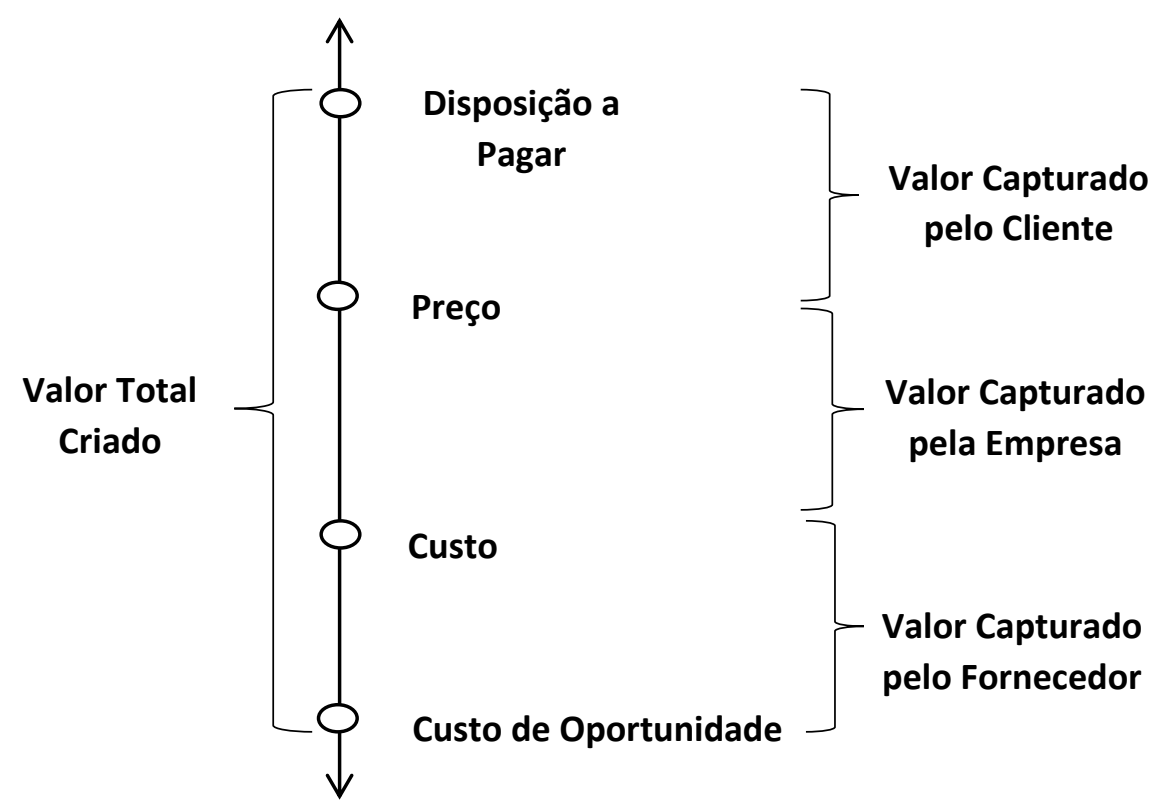

Fonte: BRANDENBURGER; STUART (1996) (tradução nossa).

É preciso definir cada uma das partes componentes do conceito de valor, o custo de oportunidade e disposição a pagar. Quando se referem ao custo de oportunidade, Ghemawat e 
Rivkin (2006) observam que é referente ao menor valor pelo qual o fornecedor está disposto a vender seus produtos e/ou serviços, preço que, de acordo com Brandenburger e Stuart (1996), é o limite inferior, ou seja, o fornecedor não esta disposto a negociar por abaixo daquele preço. A disposição a pagar, outro dos componentes do conceito tratado, refere se ao limite superior do valor que um consumidor cliente estaria disposto a pagar por adquirir um produto e/ou serviço (GHEMAWAT; RIVKIN, 2006). De acordo com Fernandes (2013) a disposição a pagar pode ser entendida como o valor que envolve toda percepção de vantagens, ganhos e benefícios de uma transação. Assim mesmo a autora salienta que os benefícios podem ser objetivos (melhoria na qualidade, redução de custos, aumento na produtividade e benefícios para o cliente final) como também podem ser subjetivos (segurança, confiança e tranquilidade).

Quatro estratégias de criação de valor são propostas por Brandenburger e Stuart (1996) que podem ser utilizadas pelas empresas: aumentar a disposição a pagar dos compradores; diminuir o custo de oportunidade dos fornecedores; diminuir a disposição a pagar dos compradores concorrentes e aumentar o custo de oportunidade dos fornecedores dos concorrentes. O objetivo do presente trabalho vai-se a analisar tendo em conta as duas primeiras estratégias, devido a que se trata especificamente da relação comercial entre os fornecedores e os clientes (empresas compradoras de orgânicos, clientes direitos e agentes intermediários).

Depois do exposto, nota-se que a prioridade competitiva será determinante para as estratégias de operações adotadas por uma organização; no caso da produção orgânica, Vilckas e Nantes (2007) sinalam que umas das opções que pode contribuir à permanência dos produtores orgânicos em novos mercados é a agregação de valor a seus produtos gerando empreendimentos mais competitivos.

\subsubsection{Formas de agregação de valor.}

Mior (2007) expõe que dois aspetos são indispensáveis no momento de se referir à agregação de valor na agroindústria rural: (i) a utilização dos produtores de seus próprios recursos como a força de trabalho, processos artesanais e produção em pequena escala, e (ii) o uso do saber - fazer (Know - how) enraizado na cultura regional.

O processo de produção orgânica e as relações entre o produtor e o cliente, poderia gerar uma possibilidade de aumentar a disposição a pagar por parte do cliente e aumentar o 
custo de oportunidade vislumbrado pelo produtor. Agne e Waquil (2011) relatam que a forma de produção agroecológica é uma representação para o cliente da preocupação com o cuidado do meio ambiente por parte do produtor, remetendo até a forma de produção livre de aditivos ou insumos químicos. Os autores reconhecem ainda seu impacto no social, devido à sua importância no momento de adquirir produtos que sejam condizentes à situação socioeconômica da população, e da mesma forma tem um impacto na cultura, tendo em conta que o consumo deste tipo de produtos é associado à busca de preservar a forma de produção proveniente da agricultura familiar (AGNE; WAQUIL, 2011).

Os conhecimentos próprios dos agricultores são importantes no momento de obter produtos agroindustriais diferenciados, os quais chegam a obter uma representação de qualidade distintiva se comparados com os produtos da grande agroindústria, diferenciação que constitui um fator estratégico para que os produtores possam se beneficiar comercialmente de uma imagem artesanal, colonial e agroecológica, o que proporcionará o acesso a mercados específicos garantindo maior margem de valor adicionado (GAZOLLA, et. al., 2012).Implantar as melhores praticas em nos melhores tempos e custos, com a melhor qualidade, flexibilidade e velocidade, faz com que as cadeias de valor consigam adicionar o melhor valor (KETCHEN; HULT, 2007). Mas as alternativas de agregação de valor presentes no setor rural são poucas, e a sua adoção é um processo que toma tempo e que deve lidar com o pensamento tradicional do produtor que rechaça essas novas alternativas (VILCKAS; NANTES, 2007), neste sentido os autores apresentam quatro formas de agregação de valor (Quadro 5) existentes na agricultura:

\section{Quadro 5 - Formas de Agregar valor.}

\begin{tabular}{|c|c|c|}
\hline $\begin{array}{c}\text { FORMAS DE } \\
\text { AGREGAÇÃO DE } \\
\text { VALOR }\end{array}$ & DESCRIÇÃO & $\begin{array}{c}\text { IMPORTÂNCIA NA } \\
\text { AGREGAÇÃO DE VALOR }\end{array}$ \\
\hline $\begin{array}{l}\text { Utilização de normas } \\
\text { de padronização }\end{array}$ & $\begin{array}{l}\text { Em relação a atributos como ao } \\
\text { tamanho e peso dos produtos, forma, } \\
\text { turgidez, coloração, grau de } \\
\text { maturação, danos mecânicos, } \\
\text { processos de produção, etc. }\end{array}$ & $\begin{array}{l}\text { Parâmetros como ferramentas } \\
\text { de gestão, coordenação do } \\
\text { sistema e segurança do produto, } \\
\text { que diferenciam produtos com } \\
\text { características similares; }\end{array}$ \\
\hline Embalagens & $\begin{array}{l}\text { Utilizam-se dois tipos principais de } \\
\text { embalagens no caso dos produtos in } \\
\text { natura: (i) Embalagem para o } \\
\text { transporte; (ii) Embalagem de } \\
\text { comercialização. }\end{array}$ & $\begin{array}{l}\text { Conservação das características } \\
\text { próprias do alimento; } \\
\begin{array}{lcc}\text { Aumento de praticidade } & \text { e } \\
\text { conveniência } & \text { para } & \text { o } \\
\text { consumidor. } & \end{array}\end{array}$ \\
\hline
\end{tabular}




\begin{tabular}{|c|c|c|}
\hline $\begin{array}{l}\text { FORMAS DE } \\
\text { AGREGAÇÃO DE } \\
\text { VALOR } \\
\end{array}$ & DESCRIÇÃO & $\begin{array}{c}\text { IMPORTÂNCIA NA } \\
\text { AGREGAÇÃO DE VALOR }\end{array}$ \\
\hline Industrialização & Eliminação de intermediários. & $\begin{array}{l}\text { Preço mais estável em relação } \\
\text { ao produto in natura, } \\
\text { possibilidade de planejar a } \\
\text { produção, atuação em novos } \\
\text { mercados e maior implantação } \\
\text { de ferramentas gerenciais. }\end{array}$ \\
\hline $\begin{array}{l}\text { Desenvolvimento da } \\
\text { marca }\end{array}$ & $\begin{array}{l}\text { O principal elemento diferenciador } \\
\text { para produtos e serviços. Facilidade } \\
\text { para o processamento de pedidos; } \\
\text { proteção legal de características } \\
\text { exclusivas do produto ou serviço; } \\
\text { proteção contra a concorrência; } \\
\text { segmentação de dercado; } \\
\text { fortalecimento da imagem da } \\
\text { corporação. }\end{array}$ & $\begin{array}{l}\text { Maior facilidade de } \\
\text { comercialização dos produtos, } \\
\text { indicação de determinados } \\
\text { padrões de qualidade, } \\
\text { fortalecimento das preferências } \\
\text { do comprador e identificação } \\
\text { dos fornecedores. }\end{array}$ \\
\hline
\end{tabular}

Fonte: Adaptado de VILCKAS; NANTES, 2007.

O consenso que se tenha em relação a quais vão a ser as prioridades competitivas, conduze à escolha de uma proposta que vai conter a maior diversidade de construtos, aumentando desta maneira a chance de encontrar a combinação de prioridades mais adaptada a uma empresa específica. De acordo com o exposto por Hill (2000) e com Paiva e Vieira (2011) as prioridades competitivas podem ser: o preço, a qualidade, a velocidade e confiabilidade de entrega, a flexibilidade para atender variações da demanda, flexibilidade para modificar os atributos do produto, a diversidade de produtos, liderança em desenho e suporte técnico. Ainda é importante ressaltar que as relações entre os conceitos discutidos concordam com as ideias de posicionamento de Edwards, Battisti e Neely (2004) e Noke e Hughes (2010) que falam que os novos ganhos de mercado ou mesmo reposicionamentos na cadeia de valor vão depender do desenvolvimento interno de novas capacidades produtivas, de terceirização, da implantação de tecnologias, ou ainda da realização de alianças estratégicas.

\subsubsection{A cadeia de valor}

O modelo teórico da cadeia de valor foi apresentado por Porter (1985), aquele modelo permite descrever as atividades imersas numa organização que visam gerar valor para o cliente final e para a mesma organização. Em outras palavras, a cadeia de valor tem como principal objetivo, contribuir na segmentação de um ramo de negócios nas suas principais 
partes constituintes. Assim, é possível analisar com maior acurácia os diversos elementos que compõem a cadeia de valor e as relações que podem ser desenvolvidas entre os integrantes da cadeia (NOKE; HUGHES, 2010). A ideia principal de Porter foca-se em que cada empresa é um conjunto de atividades planejadas para desenhar, produzir, levar até o mercado, entregar e apoiar a seus produtos, e à medida que um produto passa por cada uma destas atividades, diferentes tipos de valor serão agregados pelos distintos elos da cadeia.

Fernandes (2013) salienta que outra forma de criar valor está relacionada com a criação de parcerias estratégicas baseadas na colaboração com aqueles que têm maior potencial de gerar vantagens aos envolvidos na cadeia. Holcomb e Hitt (2007) salientam que uma estratégia baseada nas relações com fornecedores tem a capacidade de trazer grandes ganhos para uma empresa, não só na redução de custos, mas também por gerar valor através de novas competências. Parmigiani e Mitchell (2009) igualmente reconhecem a capacidade de relacionamento com fornecedores como um recurso capaz de rapidamente trazer resultados para uma organização em uma cadeia de valor.

\subsubsection{Relacionamentos colaborativos.}

O nível de sucesso de uma organização não deve estar focado só no seu próprio desempenho, mas também ele está relacionado com sua capacidade de se integrar na cadeia de suprimentos desenvolvendo relacionamentos. De acordo com Stank, Dittmann e Autry (2011) a colaboração entre o fornecedor e o cliente é fundamental na busca do desempenho financeiro em uma estratégia de cadeia de suprimentos, onde os fornecedores e clientes trabalham de forma conjunta numa relação colaborativa para a consecução de melhoras conjuntas.

Cao e Zhang (2011) defendem que num ambiente de incerteza as firmas de diferentes tamanhos, vão a gerar esforços de colaboração entre os atores dentro da cadeia de suprimentos e assim alcançarem altos níveis de colaboração, conseguindo aumentar suas capacidades e conhecimentos, os quais trazem como consequência vantagens competitivas. Os autores expõem sete fatores por meio dos quais se consegue a colaboração dentro da cadeia: o intercâmbio de informações, objetivos conjuntos, decisões sincronizadas, alinhamento de incentivos, intercâmbio de recursos, comunicação colaborativa e criação de conhecimento conjunto (CAO; ZHANG, 2011). Fernandes (2013) defende que em relacionamentos colaborativos, a confiança é um tema fundamental. 
Mayer et. al. (1995) argumentam que a literatura que trata sobre a confiança, a definem a partir de diferentes perspectivas, que aparecem com frequência na literatura e que geram a confiança nos relacionamentos: a capacidade, a benevolência e a integridade. A confiança baseada na capacidade, segundo a Mayer, Davis, e Schoorman (1995), pressupõe um desempenho altamente competente numa determinada área técnica, referindo-se com competente ao possuidor de habilidades, capacidades ou pericia. No que se referente à confiança baseada em benevolência, os autores a descrevem como uma expectativa de que a outra parte não agirá com um "lucro egocêntrico", ou seja, que a outra parte não atuará de forma oportunista. Já a confiança baseada em integridade, refere-se ao conjunto de princípios que ambas as partes encontram aceitáveis ao desenvolver o relacionamento colaborativo (MAYER; DAVIS; SCHOORMAN, 1995).

Tendo em conta o exposto acima, Dyer e Singh (1998), reconhecem que os relacionamentos colaborativos, quando percebidos como parte dos recursos da firma, são valiosos, insubstituíveis e não imitáveis, transformando-se em fonte de vantagem competitiva, neste sentido, a comunicação, a cooperação e a coordenação com fornecedores-chave, geraram benefícios às firmas compradoras do ponto de vista financeiro. Cria-se o ambiente para que os fornecedores respondam aos requerimentos do cliente quando existe uma relação colaborativa, isto vai implicar em um alto nível de comunicação corporativa em relação a temas importantes com fornecedores-chave, na realização acordos especiais com fornecedores selecionados, na manutenção de uma comunicação frequente cara a cara com fornecedores-chave, o resultado final será a lealdade aos fornecedores-chave (CARR; PEARSON, 1999).

Quando criada uma vantagem colaborativa, também é melhorado o desempenho da firma através de: compartilhamento de riscos e benefícios entre os associados da cadeia, compartilhamento de recursos, reduzidos os custos de transação, melhoria da produtividade e do desempenho financeiro. Neste caso a relação de colaboração vai gerar benefícios conjuntos (CAO; ZHANG, 2011).

Seguindo o objetivo do presente trabalho, o valor criado nos relacionamentos entre os produtores de orgânicos e os seus clientes, foi analisado atendendo a abordagem de criação de valor proposta por Brandenburger e Stuart (1996).

Para identificar quais foram os mecanismos utilizados para a criação de valor, foram escolhidas as perspectivas teóricas dos custos de transação (TCT) e a visão relacional da estratégia (VR). 


\subsection{Perspectivas teóricas.}

As teorias escolhidas para a análise do objeto do estudo foram a Teoria dos Custos de Transação (TCT), desde uma perspectiva baseada na criação de valor nos relacionamentos entre os produtores orgânicos e seus clientes, e a Visão Relacional da Estratégia (RV). De acordo com Fernandes (2013), estas duas visões teóricas podem se complementar na explicação do fenômeno da criação de valor e permitem desenvolver uma análise abrangente dos relacionamentos comerciais. Na continuação são apresentados os principais aspectos das duas teorias.

\subsubsection{A agregação de valor e a Teoria dos Custos de Transação (TCT).}

Segundo a Fernandes (2013), a TCT é uma teoria que tem grande influência nos estudos referentes aos relacionamentos nas cadeias de suprimentos, de acordo com a autora, a teoria teve sua origem nos trabalhos publicados por R. H. Coase, e tempo depois foi estruturada nos estudos do Oliver E. Williamson.

A premissa básica da TCT é a eficiência dos custos entre os componentes de uma cadeia, daí que a lógica por trás deste argumento é baseada na busca de uma estrutura de governança com características que possibilitem a redução ao mínimo dos custos de transação (DYER; CHO; CHU, 1998; RINFLEISCH; HEIDE, 1997; POPPO; ZENGER, 2002). Rinfleisch e Heide (1997) salientam que os custos de transação podem aparecer "ex ante" na elaboração e negociação de contratos e "ex post" no monitoramento e execução dos acordos. De acordo com Coase (1937) a TCT pressupõe que uma firma deverá realizar uma mesma atividade até que os custos de transação sejam equivalentes aos custos envolvidos no desenvolvimento da atividade, tais custos são os conhecidos como custos de transação, que de segundo a Fernandes (2013), Williamson (1976) classificou em custos direitos (em relação à gestão de relacionamentos) e custos de oportunidade (em relação à tomada de decisão de governança inferior). Outro aspecto da teoria, importante para o presente trabalho, refere-se à dimensão dos relacionamentos, neste sentido, Rindfleisch e Heide (1997) salientam que a TCT contém pressupostos referentes ao comportamento humano como a racionalidade limitada e o oportunismo, além das dimensões referentes às transações como a especificidade de ativos. 
A racionalidade limitada, segundo a Fernandes (2013) que amplia o argumento de Simon (1957), aborda o senso de que as pessoas, ainda tendo a intenção de tomar a melhor decisão de forma racional, elas são limitadas na sua capacidade de avaliar eficazmente todas as alternativas de decisão possíveis. Já o oportunismo, a TCT aponta a que sempre vai ter-se presente o risco de ações oportunistas e é difícil identificar de forma antecipada quem poderia ser ou não ser confiável (HOBBS, 1996).

No contexto das transações, Hobbs (1996) expõe que a especificidade de ativos se torna importante no momento em que uma das partes envolvidas no relacionamento comercial, investe em recursos específicos num transação que tem pouco ou nenhum valor em outro relacionamento, isto de acordo com Williamsom (1991) aumenta os custos na transação como consequência do risco de oportunismo. A teoria trata também a incerteza, que segundo a Hobbs (1996) pode aumentar os custos das transações e ter como consequência comportamentos oportunistas que podem dar-se como um oportunismo anterior - quando se tem omissão de informações importantes antes da transação -, e oportunismo posterior quando as atividades não são monitoradas de forma direita.

Fernandes (2013) salienta que ainda a TCT gere contribuições no momento de se estudar os relacionamentos comerciais nas cadeias de suprimentos, ela mantem limitações na sua utilização de forma exclusiva para o analise do fenômeno, dado seu foco na criação de valor através da minimização dos custos de transação. Porém, tendo em conta estas limitações, é preciso aproveitar a complementariedade que oferece a RV, e desta forma gerar uma análise mais completa do fenômeno enfocado.

\subsubsection{Visão Relacional da Estratégia (Relational View $-R V)$.}

A visão relacional ou RV surgiu a partir da Visão Baseada em Recursos (RBV), abordagem pertencente à área da estratégia e que sustenta que as empresas são heterogêneas, em relação aos seus recursos, e que alguns desses recursos serão responsáveis pela geração vantagens competitivas (MIGUEL, 2012). Já a RV de acordo com Dyer e Singh (1998) procura elucidar o que faz com que os relacionamentos entre duas firmas obtenham melhores desempenhos que outras díades, tendo como base os recursos. Os autores salientam a importância o compartilhamento dos recursos entre as firmas no momento de obter ganhos através dos relacionamentos. Fernandes (2013) argumenta que as duas teorias se diferenciam 
nas suas unidades de analises; assim a RBV tem como foco os recursos internos das firmas, enquanto a RV tem foco nos relacionamentos entre as firmas (díades).

Os recursos e as capacidades são vistos como o fundamento da estratégia em longo prazo das firmas, baseados primeiramente no intuito de que os recursos e as capacidades internas de uma firma direcionem sua estratégia (GRANT, 1991). Em um segundo momento, os recursos e as capacidades são as principais fontes de vantagens competitivas da firma (GRANT, 1991). Tem-se que um recurso só é valioso quando, a partir de uma estratégia, gera um avanço na eficiência e eficácia de uma firma, e isso é fonte de vantagem se o recurso é único (raro) comparado com os recursos da concorrência ou inimitável por parte desta (BARNEY, 1991; GRANT, 1991). Segundo a Eisenhardt e Schoohoven (1996), os relacionamentos entre as firmas podem ser fonte de recursos que por ter-se obtido dentro da relação comercial, são raros e valiosos, permitindo o compartilhamento dos riscos e os custos de transação.

Os relacionamentos comerciais colaborativos desenvolvidos entre duas firmas ou uma rede delas podem resultar em vantagens competitivas, entendidas como o valor da transação que desemboca em um desempenho superior e ganhos conjuntos (DYER; SINGH, 1998). De acordo com Dyer e Singh (1998) aquele retorno gerado no relacionamento comercial é tratado como rendas relacionais (relational rents), o qual é referente ao lucro gerado em conjunto por meio de um relacionamento especifico, o qual não poderia ser criado de forma isolada. Segundo os autores, podem ser obtidas quatro fontes de vantagens competitivas, a traves dos relacionamentos comerciais: especificidade de ativos; rotinas de intercâmbio de informações e compartilhamento de conhecimento; complementariedade de capacidades e recursos e; uma governança eficaz. A combinação destas fontes de vantagem competitiva obterão retornos partindo dos relacionamentos colaborativos desenvolvidos por meio das parcerias (DYER; SINGH, 1998). Neste sentido, têm-se três tipos de especificidade de ativos, apresentados no Quadro 6.

\section{Quadro 6 - Especificidade de ativos nos relacionamentos comerciais.}

\begin{tabular}{|c|l|}
\hline ESPECIFICIDADE DE ATIVOS & \multicolumn{1}{|c|}{ DESCRIÇÃO } \\
\hline Localização & $\begin{array}{l}\text { Redução de estoques e de custos de transporte e de } \\
\text { coordenação, devido à proximidade geográfica. }\end{array}$ \\
\hline Ativo físico & $\begin{array}{l}\text { Investimentos conjuntos em maquinas, equipamentos, } \\
\text { ferramentas, etc. que poderiam gerar diferenciação e } \\
\text { melhora na qualidade. }\end{array}$ \\
\hline
\end{tabular}




\begin{tabular}{|c|l|}
\hline ESPECIFICIDADE DE ATIVOS & \multicolumn{1}{c|}{ DESCRIÇÃO } \\
\hline \multirow{3}{*}{ Ativo humano } & $\begin{array}{l}\text { Conhecimento acumulado ao longo do tempo por meio do } \\
\text { relacionamento comercial, gerando ganhos na qualidade, } \\
\text { melhorias na comunicação interorganizacional, e no } \\
\text { mercado. }\end{array}$ \\
\hline
\end{tabular}

Fonte: adaptado de DYER; SINGH (1998); FERNANDES (2013).

O intercambio e o compartilhamento de informações e conhecimento, é um mecanismo que permite a transferência, recombinação ou criação de conhecimento especializado, atividades que tem sucesso só em presença de boa capacidade de absorção do parceiro e de incentivos para estimular a honestidade e eliminar o parasitismo (DYER; SINGH, 1998). Segundo a Dyer e Singh (1998) a complementariedade de capacidades e recursos é referente aos retornos gerados pelos diversos recursos, tangíveis ou intangíveis (capacidades, competências e reputação), existentes num relacionamento comercial que geram maiores ganhos que o total dos ganhos gerados pelos recursos obtidos de forma isolada.

Quando se leva em conta a governança eficaz, destaca-se sua importância no controle dos custos de transação e no desenvolvimento de alianças que gerem criação de rendas relacionais e inciativas de criação de valor, tendo salvaguardas como mecanismo de controle (DYER; SINGH, 1998). Os autores defendem dois tipos de governança, o primeiro trata da governança aplicada a terceiros, ou seja, contratos legais. O segundo tipo trata da governança auto aplicada, gerada por meio de salvaguardas formais e informais, as quais têm como base a confiança e a cooperação entre as partes (DYER; SINGH, 1998).

Segundo as abordagens teóricas apresentadas (TCT e RV), busca-se explicar como ocorre a criação de valor nos relacionamentos comerciais entre os produtores de orgânicos e seus clientes compradores. 


\section{METODOLOGIA}

\subsection{Descrição da pesquisa}

A pesquisa pode ser vista como a parte essencial da ciência, a qual possibilita o avanço para a busca do entendimento de uma realidade, convertendo-se em um processo perene desenvolvido por meio de aproximações sucessivas da realidade (SILVEIRA; CÓRDOVA, 2009). Segundo a Silveira e Córdova (2009) a pesquisa cientifica é o resultado do desenvolvimento de um conjunto de atividades que visam a resolução de um problema, percorrendo um caminho de procedimentos científicos. De acordo com os autores, podem-se identificar diferentes tipos de pesquisa quanto à sua abordagem, sua natureza, seus objetivos e seus procedimentos.

A presente pesquisa, quanto aos objetivos, assumiu caráter de exploratório. De acordo com Gil (2002) a pesquisa exploratória visa proporcionar maior aproximação e entendimento do problema estudado, que na maioria das vezes tem sido relativamente objeto de poucos estudos, pois existem poucos estudos sobre o tema.

No que tinge ao procedimento técnico, a pesquisa pode-se classificar como um estudo de casos múltiplos, nos quais vários estudos são dirigidos de forma simultânea, que no caso particular do trabalho foram os produtores rurais (fornecedores) e as diferentes categorias de clientes, proporcionando evidências nos diferentes contextos. Trata-se de um investimento maior de tempo para a coleta e análise de dados, devido á necessidade da aplicação da mesma ferramenta em todos os casos (GIL, 2002).

Segundo Gil (2002), o estudo de caso consiste no estudo exaustivo de um ou poucos objetos visando conhecê-lo de forma detalhada e ampla. De acordo com Fonseca (2002) o estudo de caso é caracterizado como o estudo de uma entidade bem definida, entidades que para o presente trabalho tinham características comuns, imersas num contexto definido com qualidades particulares. O objetivo do estudo de caso é conhecer em profundidade uma determinada situação que supõe ser única em diversos aspectos, respondendo os seus "como" e os seus "porquês" da situação, todo na busca de identificar o que há nela de mais essencial e característico (FONSECA, 2002). Tendo como base as correntes teóricas escolhidas, buscouse entender melhor o processo da criação de valor nos relacionamentos comerciais entre os produtores rurais (fornecedores) e seus clientes. 
Já quanto à abordagem, fora-se caracterizado como, uma parte predominantemente quantitativa e outra de predominância qualitativa. De acordo com Fonseca (2002) a pesquisa quantitativa é objetiva, que influenciada pelo positivismo lógico, considera que a compreensão da realidade só pode-se obter a partir da análise de dados brutos, cuja coleta é auxiliada por meio de uma ferramenta padronizada e neutra. Os dados coletados a partir das ferramentas quantitativas foram quantificados e analisados através de procedimentos estatísticos. Entanto, a pesquisa qualitativa preocupa-se com aspetos não mesuráveis quantitativamente da realidade, centrando-se no entendimento e explicação da dinâmica das relações (FONSECA, 2002). Nesse contexto, a utilização da abordagem qualitativa tem sido incentivada por permitir maior entendimento do fenômeno em estudo. Com tudo, Fonseca (2002) salienta a importância da utilização conjunta da pesquisa qualitativa e quantitativa, por permitirem obter maior número de informações do que se poderia conseguir de forma isolada.

\subsection{Caracterização da região local do estudo.}

A pesquisa se concentrou nas Bacias dos Rios Maranhão e São Bartolomeu, alocadas no Distrito Federal (Figura 8), pertencentes ao Território Rural das Águas Emendadas DF/GO/MG (DE CARVALHO, et. al., 2006), região Centro-oeste.

$\mathrm{Na}$ região foco da coleta dos dados da presente pesquisa, encontra-se localizado o Território da Cidadania das Águas Emendadas DF/GO/MG (Figura 8), é o único Território Rural no Brasil que reúne três unidades de federação, está localizado no Planalto Central Brasileiro, abrangendo todo o Distrito Federal, três municípios do noroeste do Estado de Minas Gerais (Buritis, Cabeceira Grande e Unaí), e sete municípios do nordeste do Estado de Goiás (Água Fria, Cabeceiras, Formosa, Mimoso, Padre Bernardo, Planaltina de Goiás e Vila Boa) (DE CARVALHO, et.al., 2006).

O território abrange uma área de $37.721,70 \mathrm{Km}^{2}$. Com uma população estimada em 2.898.988 habitantes, dos quais 146.190 vivem na área rural, o que corresponde a 5,04\% do total, possui 10.114 agricultores familiares, e 5.507 famílias assentadas (PORTAL DA CIDADANIA, 2014). O Território Rural das Águas Emendadas DF/GO/MG compreende áreas pertencentes a três grandes bacias hidrográficas brasileiras: Bacia dos Rios Araguaia e Tocantins, Bacia do Rio São Francisco e Bacia do Rio Paraná. As “Águas Emendadas” das três bacias brotam no DF, espalhando-se pelas duas outras unidades da federação deste território, Minas Gerais e Goiás (DE CARVALHO, et. al., 2006). 
Figura 9 - Mapa do Território Rural das Águas Emendadas DF/GO/MG com a localização das bacias hidrográficas dos rios Maranhão e São Bartolomeu - DF.

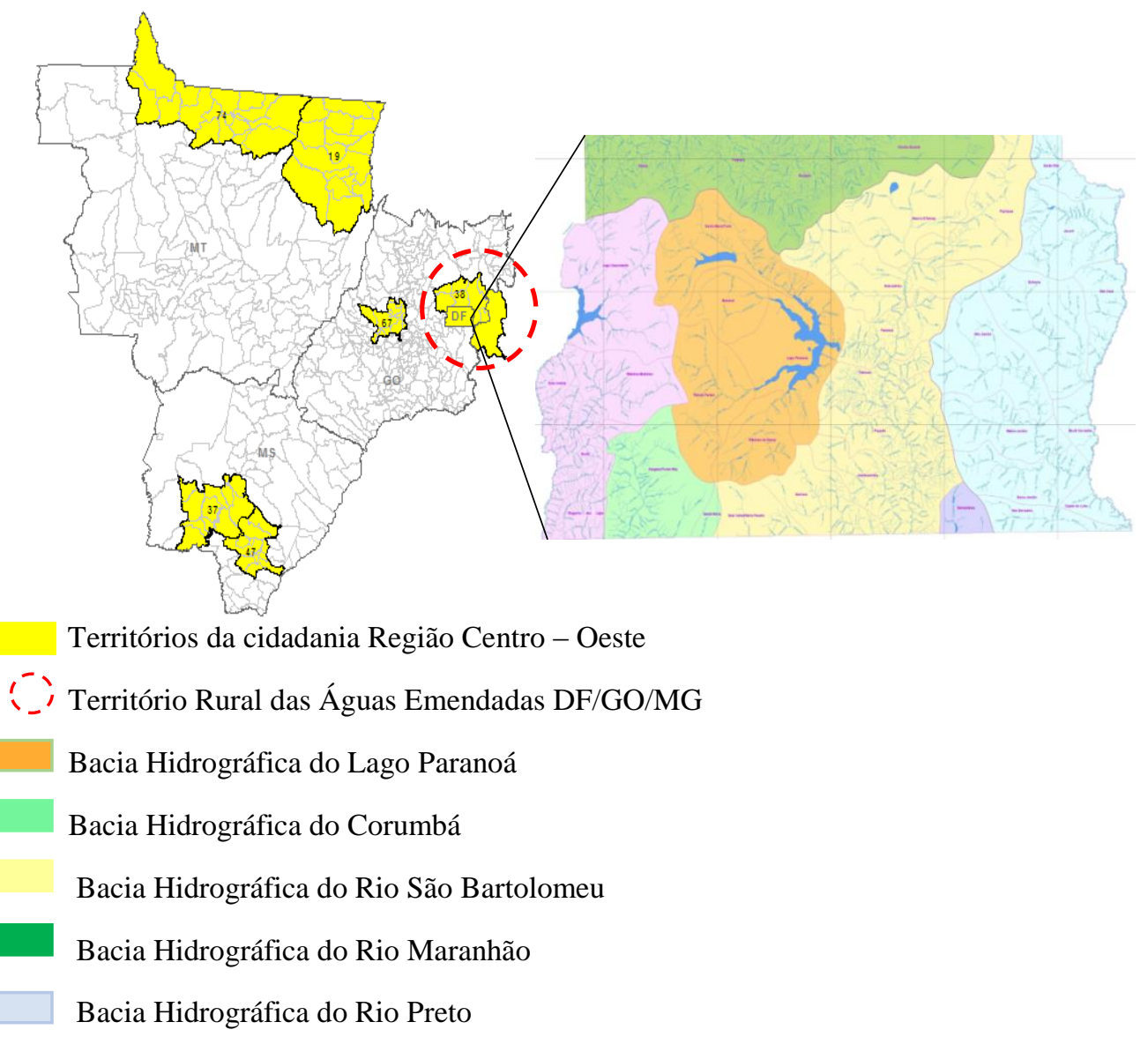

Fonte: ADASA, 2014.

O bioma cerrado cobre 200 milhões de hectares (23\% do território brasileiro), ocorrendo na totalidade do Território Rural das Águas Emendadas DF/GO/MG, apresentando clima tropical com precipitações pluviométricas variadas (entre $750-2.000 \mathrm{~mm} / \mathrm{ano}$ ) (DE CARVALHO, et. al., 2006). O cerrado é caracterizado por ser um bioma complexo, apresentando diversificação da fisionomia de sua vegetação, assim, sua cobertura vegetal varia desde extensos campos, com predominância de vegetação herbácea, onde podem ocorrer árvores e arbustos de pequeno porte em baixa densidade, até florestas recobertas por árvores de grande porte, distribuídas em alta densidade; da mesma forma, sua diversidade botânica é tida como a mais alta entre as savanas do mundo, fato que se deve, em grande parte, a posição geográfica do cerrado em relação aos demais biomas brasileiros - está interligado a Amazônia, Caatinga, Pantanal e Floresta Atlântica (DE CARVALHO, et. al., 2006; RIBEIRO; WALTER, 2007). 
O DF uma das unidades federativas pertencentes ao Território da Cidadania das Águas Emendadas DF/GO/MG, conta com uma área de $5.814 \mathrm{Km}^{2}$ e uma população de aproximadamente 2.000.000 de habitantes está situado numa região de terras altas, pelo que é visto como o dispersor das drenagens que fluem para as três bacias já citadas acima (IBRAM, 2012). De acordo com o IBRAM (2012) a intensificação das atividades econômicas no setor agropecuário no DF gera uma forte pressão sobre os recursos naturais, colocando em risco o uso sustentável da água, dos solos e da floresta. A atividade agropecuária é de relevante importância econômica na região do entorno do DF, ressaltando que as maiores áreas de solo são ocupadas com cultura de grãos e pastagem artificial, ficando a fruticultura e a horticultura com áreas menores (DE CARVALHO, et. al., 2006). De acordo com De Carvalho, et. al. (2006), a agricultura varia desde a subsistência até a produção de grandes culturas de cereais, principalmente soja, milho e feijão, culturas que se tem expandido em áreas anteriormente ocupadas por cerrado, sendo utilizados corretivos e fertilizantes nos solos, para compensar as deficiências naturais.

O programa Territórios da Cidadania objetiva a criação de um espaço que promova o planejamento, a implementação e a autogestão do processo de desenvolvimento sustentável dos territórios rurais, centrando-se na diversidade cultural, visando fortalecer e dinamizar sua economia, (GARBIN et. al. 2006; DE CARVALHO, et. al., 2006). Salienta-se que um dos desafios que enfrenta o programa é integrar o desenvolvimento econômico e a preservação do ambiente, pois de acordo com De Carvalho et. al. (2006), apesar de que o DF possui diversas áreas legalmente protegidas no território rural das Águas Emendadas ainda existem grandes espaços de importância ambiental que não estão conservados.

Neste sentido, Feistauer (2012) reconhece que a aprovação do novo código florestal brasileiro (NOVO CÓDIGO FLORESTAL LEI No 12.651, DE 25 DE MAIO DE 2012), poderia contribuir em parte à resolução dos problemas jurídicos e legais dos produtores. Mas seguirão existindo áreas degradadas, tanto de Reserva Legal quanto de Áreas de Preservação Permanente, consequência de alterações como a expansão da fronteira agrícola e pecuária nestes territórios, e a situações de graves conflitos ambientais quanto à ocupação do solo e uso dos recursos hídricos em as principais bacias hidrográficas do Distrito Federal (IBRAM, 2012). É importante salientar que, no território de Águas Emendadas, apenas uma ínfima parte da sua área foi transformada em unidades de conservação - exceção feita ao Distrito Federal (DE CARVALHO, et al., 2006). 


\subsection{Identificação da amostra.}

No presente trabalho, tentou-se conseguir uma triangulação das evidencias obtidas de diversas fontes de dados primários e secundários. Assim os dados primários foram obtidos através de formulários de perguntas, entrevistas semi-estruturadas e observação direta. Foram selecionados como objetos do estudo: i) produtores de orgânicos (fornecedores) e ii) os clientes (Quadro 7). Conforme descrito por Meredith (1998) um estudo de caso utiliza múltiplos métodos e ferramentas na coleta dos dados em um entorno único considerando aspetos temporais e contextuais do fenômeno estudado, mas sem controle experimental ou manipulação. As ferramentas e os métodos incluem tanto métodos quantitativos como qualitativos, como dados financeiros, entrevistas, planos de negócios, organogramas, questionários, e observação direta ou utilizando ações e interações; todo com o objetivo de compreender da forma mais completa possível o fenômeno estudado a traves da triangulação das evidencias acumuladas de variadas fontes de dados, visando obter um alto nível de validez da unidade pesquisada (BONOMA, 1985; MEREDITH, 1998).

Foram entrevistadas pessoas de ambas as amostras com o objetivo de compreender a percepção de criação de valor para cada extremo envolvido. Já os dados secundários, foram obtidos por meio da revisão de documentos como relatórios corporativos, dados do mercado de orgânicos, pesquisas relacionadas com o setor e sites institucionais. Com todas estas abordagens, foi possível explorar o fenômeno pesquisado de forma mais completa.

Quadro 7 - Identificação e descrição da amostra.

\begin{tabular}{|c|c|c|c|c|}
\hline AMOSTRAS & $\begin{array}{l}\text { UNIDADES } \\
\text { AMOSTRAIS }\end{array}$ & $\mathbf{N}^{\circ}$ & DESCRIÇÃO & OBJETIVO \\
\hline $\begin{array}{l}\text { Propriedades } \\
\text { rurais } \\
\text { agricultura } \\
\text { familiar. }\end{array}$ & $\begin{array}{l}\text { Produtores (as) } \\
\text { rurais. }\end{array}$ & 16 & 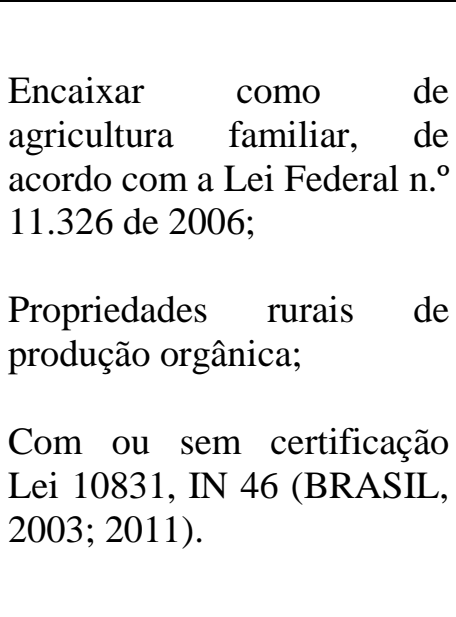 & $\begin{array}{l}\text { Avaliar a aderência das } \\
\text { propriedades rurais à } \\
\text { legislação orgânica e } \\
\text { ambiental; }\end{array}$ \\
\hline
\end{tabular}




\begin{tabular}{|c|c|c|c|c|}
\hline AMOSTRAS & $\begin{array}{c}\text { UNIDADES } \\
\text { AMOSTRAIS }\end{array}$ & $\mathbf{N}^{\circ}$ & DESCRIÇÃO & OBJETIVO \\
\hline $\begin{array}{l}\text { Feiras de } \\
\text { orgânicos }\end{array}$ & $\begin{array}{l}\text { Clientes das } \\
\text { feiras de } \\
\text { orgânicos }\end{array}$ & 10 & $\begin{array}{l}\text { Clientes com um tempo com } \\
\text { relacionamento comercial } \\
\text { com o produtor }>1 \text { ano }\end{array}$ & $\begin{array}{l}\text { Entender a visão dos } \\
\text { clientes no referente à } \\
\text { percepção de criação de } \\
\text { valor; } \\
\text { Identificar ou validar os } \\
\text { processos de criação de } \\
\text { valor informados pelos } \\
\text { produtores. }\end{array}$ \\
\hline \multirow{4}{*}{$\begin{array}{c}\text { Agentes } \\
\text { Intermediários }\end{array}$} & $\begin{array}{l}\text { Mercadinhos, } \\
\text { lojas, varejões. }\end{array}$ & 3 & \multirow{3}{*}{$\begin{array}{l}\text { Clientes com um tempo com } \\
\text { relacionamento comercial } \\
\text { com o produtor > } 1 \text { ano; } \\
\text { Comercialização inclui } \\
\text { produtos orgânicos. }\end{array}$} & \multirow{4}{*}{$\begin{array}{l}\text { Entender a visão dos } \\
\text { agentes intermediários } \\
\text { no referente à percepção } \\
\text { de criação de valor; } \\
\text { Identificar ou validar os } \\
\text { processos de criação de } \\
\text { valor informados pelos } \\
\text { produtores. }\end{array}$} \\
\hline & Supermercados & 4 & & \\
\hline & Restaurantes & 5 & & \\
\hline & $\begin{array}{c}\text { Mercado } \\
\text { Institucional }\end{array}$ & 2 & $\begin{array}{l}\text { Compras } \\
\text { Sustentáveis (CPS) por meicas } \\
\text { do Programa de Aquisição } \\
\text { de Alimentos (PAA) }\end{array}$ & \\
\hline
\end{tabular}

Fonte: Desenvolvido pelo autor.

O levantamento de dados foi realizado no ano 2014 no período que compreendeu os meses de março e julho, por meio de visitas in loco, entrevistas e aplicação dos formulários de perguntas (Apêndice A, B e C), com uma duração média de 50 minutos no total em cada visita. Todas as entrevistas forma desenvolvidas pelo autor de forma presencial junto aos entrevistados (Quadro 7).

A seleção da região e do tamanho da amostra, propriedades rurais agricultura familiar, foi intencional por conveniência e acessibilidade, devido a que se tiveram alianças estratégicas em diferentes segmentos: colaboração do Instituto Brasília Ambiental (IBRAM) na localização dos perímetros das propriedades em estudo em relação ao território Distrital e à divisão de Bacias Hidrográficas, assim como na avaliação dos perímetros, no intuito de informar a situação de adequação ambiental quanto às áreas de reserva legal e de preservação permanente nas propriedades rurais da região e; o apoio logístico do Serviço Brasileiro de Apoio às Micro e Pequenas Empresas (SEBRAE), quem por meio do serviço de extensão forneceu ajuda com o traslado até as propriedades, além do acompanhamento e orientação na aplicação das entrevistas na a coleta dos dados. Da mesma forma, a seleção das amostras, clientes das feiras de orgânicos e agentes Intermediários foi intencional por conveniência e acessibilidade. 


\subsection{Produtores Rurais: Adequação à legislação orgânica e ambiental e criação de valor.}

Na primeira fase da pesquisa foi realizada a avaliação do nível de transição agroecológica das propriedades abraçadas na amostra, localizadas na área de abrangência das bacias hidrográfica dos rios Maranhão e São Bartolomeu por meio da adaptação do sistema de avaliação e quantificação da transição agroecológica proposto por Feistauer (2012) adaptado segundo marco referencial em agroecologia (EMBRAPA, 2006) em consonância com o processo de conversão para sistemas orgânicos de produção (BRASIL, 2003; 2011). Em um segundo momento foi avaliado o nível de conhecimento e aderência à legislação ambiental das propriedades tendo em conta aspetos referentes às áreas de reserva legal (RL) e de preservação permanente (APP) e da qualidade destas áreas, apresentando com principal fonte de dados, as percepções dos produtores rurais. Finalmente buscou-se identificar os mecanismos de criação de valor, adotados pelos produtores, a partir da adesão á legislação orgânica e ambiental.

\subsubsection{Avaliação do nível de transição agroecológica.}

O sistema quantitativo de avaliação da transição agroecológica foi desenvolvido segundo Feistauer (2012), sendo adaptado e utilizado para mesurar o nível de transição agroecológica das propriedades rurais na área de abrangência das bacias hidrográficas dos rios Maranhão e São Bartolomeu, reconhecendo três níveis de transição agroecológica, o primeiro nível foi denominado de substituição de técnicas convencionais por técnicas eficientes, o segundo nível de transição foi denominado de substituição de insumos sintéticos por orgânicos e implementação de práticas alternativas; e o terceiro nível de transição agroecológica foi denominado de redesenho dos agroecossistemas.

De acordo com Feistauer (2012), a metodologia manipula um conjunto de informações relacionadas ao manejo agroecológico das propriedades rurais, que para o caso da presente pesquisa, foram obtidas por meio de um formulário (Apêndice A) preenchido conjuntamente com o agricultor (a). Para cada parâmetro de resposta do formulário foi atribuído um valor (Quadro 8) que varia de zero (0) como o mínimo ou indesejável, a três (3) como máximo ou desejável (FEISTAUER, 2012). 


\section{Quadro 8 - Avaliação quantitativa dos níveis de transição agroecológica em propriedades rurais.}

\begin{tabular}{|c|c|c|c|}
\hline \multicolumn{3}{|c|}{ TRANSIÇÃO AGROECOLÓGICA. } & \multirow{2}{*}{ Valor } \\
\hline$\longrightarrow$ Indicador & Coeficiente $=1$ & & \\
\hline \multicolumn{3}{|c|}{ 1.1. Práticas do controle de plantas espontâneas e manejo de limpeza de área para plantios } & \\
\hline \multicolumn{3}{|c|}{ agrícolas. } & \lceil \\
\hline \multicolumn{3}{|c|}{$\begin{array}{ll}\text { () Utiliza herbicida ou fogo associado a capina e roçadas. } & \text { Valores dos }\end{array}$} & \\
\hline \multirow{2}{*}{\multicolumn{3}{|c|}{$\begin{array}{l}\text { ( ) Utiliza herbicida ou fogo em áreas isoladas associado a capina e roçadas } \\
\text { ( ) Utiliza apenas a prática cultural da roçada e capina manual ou mecânica }\end{array}$}} & \\
\hline & & & 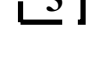 \\
\hline
\end{tabular}

Fonte: Adaptado de Feistauer (2012); Embrapa (2006); Brasil (2003; 2011).

De acordo com a metodologia, foram ponderados os parâmetros de resposta, tendo em conta que não todos os parâmetros tiveram o mesmo peso em relação à transição agroecológica. Para cada Sub-Nível de transição agroecológica (Quadro 8) foram conferidos coeficientes de 1, 2 e 3 (Sub-Nível 1 = 1; Sub-Nível 2 = 2 e; Sub-Nível $3=3$ ); isto com a finalidade de obter valores dos Sub-Níveis de acordo com sua importância (SARANDÓN; FLORES, 2009).

O calculo da transição agroecológica $\left(\mathrm{TA}_{\mathrm{n}}\right)$ correspondente aos Sub-Níveis obedece ao somatório dos valores obtidos dos parâmetros em cada Sub-Nível multiplicado pelo coeficiente correspondente (Equações $\mathrm{TA}_{1}, \mathrm{TA}_{2}$ e $\mathrm{TA}_{3}$ ). Desta forma os parâmetros de resposta pertencentes ao Sub-Nível 1 apresentaram pesos relativos menores aos parâmetros de resposta pertencentes aos Sub-Níveis 2 e 3, entendendo-se que a complexidade do agroecossistema e o processo de transição agroecológica do Sub-Nível 3 estariam em um nível mais avançado de sustentabilidade (FEISTAUER, 2012).

$$
\begin{array}{ll}
\text { Sub-Nível 1 }=\sum(1.1+1.2+1.3+1.4+1.5+1.6) * 1 & \text { Equação } T A_{1} \\
\text { Sub-Nível } 2=\sum(2.1+2.2+2.3+2.4+2.5) * 2 & \text { Equação } T A_{2} \\
\text { Sub-Nível 3 }=\sum(3.1+3.2+3.3+3.4+3.5) * 3 & \text { Equação } T A_{3}
\end{array}
$$


De acordo com a metodologia proposta por Feistauer (2012), o somatório dos três Sub-Níveis de transição agroecológica equivale a um valor de transição agroecológica total (TA) de cada propriedade (Equação TA).

Nível de Transição Total $(T A)=\sum($ S.Nível $1+$ S. Nível $2+$ S. Nível 3) Equação TA

Com tudo, as propriedades rurais puderam apresentar níveis de transição agroecológica com valores dispersos, alcançando um valor máximo de noventa e três (93) e um mínimo de zero (0), de aí que Fernandes (1999) argumente que as medidas centrais não ministram a informação completa em relação ao conjunto de valores, sendo necessário fornecer informação sobre a variação ou dispersão da distribuição dos dados. De acordo com isto, Feistauer (2012) atribuiu limites de intervalos de quartéis à classificação dos níveis de transição agroecológica $(0-31 ; 32-62 ; 63-93)$ supondo uma distribuição normal dos dados no intervalo de zero (0) a noventa e três (93). No Quadro 9 são apresentados os valores médios atribuídos a cada nível de transição agroecológica, indicando que quanto maior for o valor correspondente, será maior o nível de transição agroecológica da propriedade avaliada (FEISTAUER, 2012).

Quadro 9 - Valores atribuídos aos níveis de transição agroecológica.

\begin{tabular}{|c|c|c|c|c|}
\hline $\begin{array}{c}\text { NíVEL DE } \\
\text { TRANSIÇÃo }\end{array}$ & $\begin{array}{c}\text { Valor } \\
\text { Máximo do } \\
\text { Sub-Nível }\end{array}$ & $\begin{array}{c}\text { Peso } \\
\text { (Sub-Nível) }\end{array}$ & $\begin{array}{c}\text { Valor } \\
\text { Máximo total }\end{array}$ & $\begin{array}{c}\text { Classificação do } \\
\text { Nível de Transição }\end{array}$ \\
\hline 1 & 18 & 1 & 18 & 0 a 31 \\
\hline 2 & 15 & 2 & 30 & 32 a 62 \\
\hline 3 & 15 & 3 & 45 & 63 a 93 \\
\hline \multicolumn{3}{|c|}{ TOTAL } & $\mathbf{9 3}$ & $\mathbf{0 ~ a ~ 9 3}$ \\
\hline
\end{tabular}

Fonte: Adaptado de FEISTAUER, 2012.

Uma vez feito o cálculo (Equação TA) foram classificadas as propriedades rurais no respectivo nível de transição agroecológica de acordo com o Quadro 9. Com os dados obtidos através do formulário instrumento de coleta de dados (Apêndice A) foi feita a análise estatística aplicando o teste $t$-student para a comparação entre as médias dos valores de transição agroecológica das propriedades rurais, em nível de significância de cinco por cento (5\%) de probabilidade. 


\subsubsection{Avaliação da aderência à legislação ambiental.}

Aplicaram-se formulários (Apêndice B) com questões referentes a aspectos da legislação ambiental especificamente no referente a duas unidades de análise (Quadro 10): i) conhecimento da legislação ambiental, ii) adequação à legislação ambiental.

Quadro 10 - Unidades de análise - áreas de preservação permanente - APP, e de reserva legal - RL, na avaliação da aderência à legislação ambiental.

\begin{tabular}{|c|c|c|}
\hline $\begin{array}{l}\text { UNIDADE DE } \\
\text { ANÁLISE }\end{array}$ & $\begin{array}{l}\text { SUB- UNIDADE } \\
\text { DE ANÁLISE }\end{array}$ & INDICADORES \\
\hline $\begin{array}{l}\text { Conhecimento } \\
\text { da legislação } \\
\text { ambiental }\end{array}$ & $\begin{array}{c}\text { Área de } \\
\text { Preservação } \\
\text { Permanente - APP } \\
\text { Reserva Legal - RL }\end{array}$ & $\begin{array}{l}\text { Possui licenciamento ambiental (LAU) a propriedade? } \\
\text { Possui averbação da RL? } \\
\text { Alguma vez tentou fazer a diligencia de averbação da } \\
\text { RL? } \\
\text { Conhece como deve fazer-se a delimitação das áreas } \\
\text { de APP na propriedade? } \\
\text { Conhece o regime de proteção das áreas APP? } \\
\text { Qual é o percentual de RL necessário para a } \\
\text { propriedade? }\end{array}$ \\
\hline $\begin{array}{c}\text { Adequação à } \\
\text { legislação } \\
\text { ambiental }\end{array}$ & $\begin{array}{c}\text { Área de } \\
\text { Preservação } \\
\text { Permanente - APP }\end{array}$ & $\begin{array}{l}\text { Área da RL dentro da propriedade; } \\
\text { Área de APP dentro da propriedade; } \\
\text { Área de mata na APP localizada em nascentes; } \\
\text { Área de mata na APP localizada nas margens do(s) } \\
\text { córrego(s) e/ou nascentes localizadas na propriedade; }\end{array}$ \\
\hline
\end{tabular}

Fonte: adaptado de FEISTAUER (2012); Brasil (2012).

O estudo destas duas unidades de análise (Quadro 10) visou verificar o nível de conhecimento e de adequação dos produtores rurais em relação à legislação ambiental aplicada para cada propriedade (FEISTAUER, 2012).

Além da aplicação dos formulários, foram registrados pontos geográficos que delimitam as propriedades, com o apoio de um equipamento GPS Map 76CSx (instrumento de posicionamento global). Os dados geoespaciais obtidos foram compilados com o objeto de elaborar os mapas das propriedades rurais. O software utilizado foi o Google Earth 7.1.2. 
2014, sistema operacional Microsoft Windows (6.2.9200.0). A medição das áreas foi feita com o apoio do software QGIS 2.4 Chugiak ferramenta que permite medir, criar, editar, visualizar e analisar informações geoespaciais, superpondo pontos ou mapas, além das informações obtidas da Aerofoto de 2013 (CODEPLAN, 2013).

Contou-se com o apoio e orientação do IBRAM, no delineamento dos mapas das propriedades rurais e por meio de interpretação visual segundo a legislação pertinente (BRASIL, 2012), foram identificadas as áreas de reserva legal (RL) e de preservação permanente (APP), assim como as áreas de floresta e as áreas desflorestadas das propriedades para logo quantificá-las e comparara-las com a legislação ambiental tendo em conta o porcentual mínimo necessário de RL e APP para cada propriedade rural (FEISTAUER, 2012).

\subsubsection{Identificação dos mecanismos de criação de valor nos relacionamentos comerciais entre produtores e clientes a partir da adesão à legislação orgânica e ambiental.}

A metodologia qualitativa utilizada nesta seção foi adaptada de Fernandes (2013), e visou compreender os processos de criação de valor utilizados pelos produtores rurais, a partir da análise da criação de valor nos relacionamentos comerciais entre os produtores rurais e os seus clientes, identificando e descrevendo os mecanismos de criação de valor nestes relacionamentos (FERNANDES, 2013). Os dados foram coletados a partir de formulários de perguntas baseadas nos tópicos presentes na revisão de literatura realizada, e tiveram conteúdos específicos para cada amostra (Apêndice C).

A amostra foi dividida em três unidades de análise: i) fornecedores (produtores rurais), ii) os relacionamentos comerciais entre os fornecedores e clientes e, iii) os processos de criação de valor (FERNANDES, 2013). As unidades de análise foram tratadas com a metodologia de análises de conteúdo que contempla três etapas principais (Quadro 11): i) préanálise, ii) exploração do material e, iii) tratamento dos resultados, inferência e interpretação. (BARDIN, 1977; OLIVEIRA, 2008).

\section{Quadro 11 - Fases do método de análise de conteúdo.}

\begin{tabular}{|c|l|}
\hline FASE & \multicolumn{1}{c|}{ DESCRIÇ̃̃O } \\
\hline \multirow{3}{*}{ Pré- Análise } & $\begin{array}{l}\text { Organiza do material a ser analisado tendo em conta quatro } \\
\text { etapas: (i) estabelecimento de contato com os documentos da } \\
\text { coleta de dados; (ii) escolha dos documentos serão analisados; } \\
\text { (iii) formulação das hipóteses; (iV) determinação de indicadores } \\
\text { por meio de recortes de texto nos documentos de análise. }\end{array}$ \\
\hline
\end{tabular}




\begin{tabular}{|l|l|}
\hline \multicolumn{1}{|c|}{ FASE } & \multicolumn{1}{|c|}{ DESCRIÇÃO } \\
\hline Exploração do Material & $\begin{array}{l}\text { Definição de categorias (codificação), identificação das } \\
\text { unidades de registro (categorização e contagem frequencial), } \\
\text { identificação das unidades de contexto nos documentos } \\
\text { (segmento). }\end{array}$ \\
\hline $\begin{array}{l}\text { Tratamento dos Resultados, } \\
\text { Inferência e Interpretação. }\end{array}$ & $\begin{array}{l}\text { Condensação e o destaque das informações para análise, } \\
\text { culminando nas interpretações; é o momento da intuição, da } \\
\text { análise reflexiva e crítica }\end{array}$ \\
\hline
\end{tabular}

Fonte: adaptado de BARDIN, 1977; MOZZATO; GRZYBOVSKI, 2011.

A primeira unidade de análise referida aos produtores rurais, que foi definida como fornecedores para seu melhor entendimento, esta composta por as dez e seis (16) unidades de produção. Criaram-se pra esta unidade de análise, três categorias relativas à estratégia adotada pelos fornecedores para a criação de valor (FERNANDES, 2013) a partir dos dados coletados (Quadro 12).

Quadro 12 - Categorias da unidade de análise - Fornecedores.

\begin{tabular}{|c|c|}
\hline CATEGORIAS & INDICADOR \\
\hline Estratégia ou Proposta de valor & $\begin{array}{l}\text { Inovação; } \\
\text { Processamento mínimo (Lavar, cortar, envalar, } \\
\text { etc.). }\end{array}$ \\
\hline Fonte Interna de Valor & $\begin{array}{l}\text { Certificação orgânica ou em processo de } \\
\text { certificação; } \\
\text { Segurança alimentar; } \\
\begin{array}{l}\text { Cuidado com o meio ambiente e os recursos } \\
\text { naturais. }\end{array}\end{array}$ \\
\hline Foco da criação de valor & $\begin{array}{l}\text { Fornecedor; } \\
\text { Cliente. }\end{array}$ \\
\hline
\end{tabular}

Fonte: Adaptado de FERNANDES, 2012.

A unidade de análise "relacionamentos comerciais" constituiu-se de duas (2) das cinco (5) díades possíveis com os seus diferentes clientes, quais sejam: i) díade entre o fornecedor de orgânicos e os clientes das feiras; e ii) díade entre o fornecedor de orgânicos e o mercado institucional. Para a unidade de análise "relacionamentos comerciais" criaram-se duas categorias relativas às características dos possíveis relacionamentos comerciais entre o fornecedor e seus clientes (FERNANDES, 2013) baseando-se nos conceitos encravados no referencial bibliográfico e teórico (Quadro 13). 
Quadro 13 - Categorias da unidade de análise - Relacionamentos comerciais.

\begin{tabular}{|c|c|c|}
\hline CATEGORIAS & SUB-CATEGORIAS & INDICADOR \\
\hline \multirow{10}{*}{$\begin{array}{l}\text { Relacionamento } \\
\text { Comercial }\end{array}$} & \multirow{6}{*}{$\begin{array}{l}\text { Relacionamento } \\
\text { Colaborativo }\end{array}$} & Relacionamentos baseados em confiança; \\
\hline & & $\begin{array}{l}\text { Relacionamentos baseados na concordância } \\
\text { dos objetivos; }\end{array}$ \\
\hline & & $\begin{array}{l}\text { Relacionamentos } \quad \text { baseados } \\
\text { desenvolvimentos conjuntos; }\end{array}$ \\
\hline & & $\begin{array}{l}\text { Relacionamentos baseados } \\
\text { compartilhamento de recursos; }\end{array}$ \\
\hline & & $\begin{array}{l}\text { Relacionamentos baseados na troca de } \\
\text { informações, e conhecimento; }\end{array}$ \\
\hline & & $\begin{array}{l}\text { Relacionamentos baseados na comunicação } \\
\text { colaborativa; }\end{array}$ \\
\hline & & $\begin{array}{l}\text { Relacionamentos baseados em contratos com } \\
\text { de caráter rigoroso; }\end{array}$ \\
\hline & $\begin{array}{l}\text { Relacionamento } \\
\text { Transacional }\end{array}$ & $\begin{array}{l}\text { Relacionamentos baseados em mecanismos de } \\
\text { salvaguardas; }\end{array}$ \\
\hline & & $\begin{array}{l}\text { Relacionamentos baseados no controle de } \\
\text { custos. }\end{array}$ \\
\hline & Relacionamento Misto & $\begin{array}{l}\text { Características de } \\
\text { colaborativos e transacionais. }\end{array}$ \\
\hline \multirow{3}{*}{ Valor Criado } & $\begin{array}{l}\text { Aumento da } \\
\text { Disposição a Pagar } \\
\text { (DP). }\end{array}$ & $\begin{array}{l}\text { Valor criado percebido pela empresa } \\
\text { cliente. }\end{array}$ \\
\hline & $\begin{array}{l}\text { Redução do Custo de } \\
\text { Oportunidade. }(\mathrm{CO})\end{array}$ & Valor criado percebido pelo fornecedor. \\
\hline & $\begin{array}{l}\text { Aumento DP + } \\
\text { Redução do CP. }\end{array}$ & $\begin{array}{l}\text { Valor criado percebido pelo fornecedor e o } \\
\text { seus clientes. }\end{array}$ \\
\hline
\end{tabular}

Fonte. Adaptado de FERNANDES, 2012.

Finalmente a unidade de análise chamada de processos de criação de valor foi composta por trinta e dois (32) processos os quais se puderam identificar mediante os relacionamentos comerciais entre os fornecedores e seus clientes. Para a análise desta unidade seguiu-se a metodologia do Process-tracing utilizada por Fernandes (2013) na análise dos 
relacionamentos de empresas produtoras de embalagens (empresas focais) com seus clientes e fornecedores de insumos.

De acordo com George e Bennett (2005) o Process-tracing ou mapeamento de processo objetiva identificar os processos causais que intervêm entre uma variável dependente e uma ou mais variáveis independentes. De acordo com Fernandes (2013) o Process-tracing é apropriado no estudo da criação de valor nos relacionamentos, argumentado que permite uma análise detalhada da cadeia causal e dos mecanismos causais presentes na criação de valor. A metodologia baseia-se em narrativas guiadas pela consistência com a teoria, dos acontecimentos causais relevantes de diversas relações de causa e efeito, envolvendo a justaposição das narrativas visando a identificação de regularidades, objetivando desenvolver, testar ou criar novas teorias (FERNANDES, 2013).

A forma de implantar o Peocess-tracing requer uma procura das diversas variáveis que possam influenciar no processo causal percorrido (FERNANDES, 2013). Para efeitos da presente pesquisa, a procura das variáveis teve o apoio de um formulário de perguntas (Apêndice C), o qual listou questionamentos visando delinear a maior quantidade de fatores capazes de elucidar o fenômeno pesquisado (Quadro 14).

\section{Quadro 14 - Marco estrutural do processo de criação de valor no relacionamento comercial Fornecedor - cliente.}

\begin{tabular}{|c|l|}
\hline ETAPAS & \multicolumn{1}{|c|}{ DESCRIÇÃO } \\
\hline Inicio & $\begin{array}{l}\text { Situação que iniciou o relacionamento comercial; } \\
\text { Quem iniciou o relacionamento comercial }\end{array}$ \\
\hline $\begin{array}{c}\text { Desenvolvimento } \\
\text { do processo }\end{array}$ & $\begin{array}{l}\text { Quem desenvolveu o processo relacional; } \\
\text { Que fatores são necessários para que o processo de criação de valor sucedesse; } \\
\text { Benefícios gerados no relacionamento; } \\
\text { Tempo que tem o relacionamento comercial; } \\
\text { Descrição da participação de cada um dos envolvidos no relacionamento } \\
\text { comercial; } \\
\text { Possíveis conflitos ou problemas gerados no relacionamento comercial. }\end{array}$ \\
\hline Geração de ativos & Materialização do processo de criação de valor no relacionamento comercial. \\
\hline Fonte. Adaptado de FERNANDES, 2013.
\end{tabular}

Uma vez estruturados os processos de criação de valor, foram comparados os caminhos causais que cada processo apresentou, visando esclarecer os mecanismos causais típicos da criação de valor nos relacionamentos comerciais entre os fornecedores e os seus clientes. 


\subsection{Percepção dos clientes quanto à criação de valor.}

Observou-se o emprego da mesma metodologia do numeral 3.4 .3 na avaliação da percepção dos clientes quanto à criação de valor. Para o desenvolvimento desta etapa da pesquisa, foram feitas entrevistas e aplicados formulários de perguntas (Apêndice C) em relação à percepção de valor criado e aos processos de criação de valor dos agentes intermediários. Os seguintes segmentos do mercado de produtos orgânicos no Distrito Federal foram abordados: Supermercados (4 unidades); Varejo de pequeno porte (Mercadinhos, lojas, varejões; 3 unidades); e Restaurantes (5 Unidades).

As entrevistas foram feitas com a finalidade de identificar ou validar os processos de criação de valor informados pelos produtores e de identificar as estratégias que poderiam adotar os produtores rurais para criar valor e assim obter maior participação no mercado formal de orgânicos.

Além se levaram em conta três unidades de analise: i) Mercado cliente de produtos orgânicos; ii) Relacionamentos comerciais: percepção do mercado cliente; e iii) processos de criação de valor: percepção do mercado cliente.

Para o tratamento da unidade de analise Mercado cliente de produtos orgânicos, levou-se em conta as categorias Estratégia ou Proposta de valor, Fonte Interna de Valor, Foco da criação de valor. Quanto que a unidade de análise "Relacionamentos comerciais: percepção do mercado cliente" constituiu-se de 3 díades com os seus fornecedores, sendo tratadas de acordo com as categorias relativas às características dos possíveis relacionamentos comerciais implementadas na analise dos relacionamentos entre os produtores e os seus clientes: Relacionamento Comercial e Valor criado.

Por ultimo, para o tratamento da unidade de analise processos de criação de valor: percepção do mercado cliente, seguiu-se a metodologia do Process-tracing, levando em conta as três etapas no processo da criação de valor propostas por Fernandes (2013): Inicio, Desenvolvimento do processo e Geração de ativos. 


\section{RESULTADOS E DISCUSSÃO}

\subsection{Produtores Rurais: adequação à legislação orgânica e ambiental e criação de valor.}

Foram analisados os dados obtidos na pesquisa visando atingir o objetivo de identificar as estratégias adotadas por produtores rurais praticantes do sistema de produção orgânica, na criação de valor nos relacionamentos comerciais fornecedor - cliente, a partir da adequação à legislação orgânica e ambiental. Foram analisadas e feitas entrevistas a um total de 16 propriedades rurais.

\subsubsection{Avaliação do nível de transição agroecológica das propriedades rurais.}

Inicialmente foram agrupados e criados códigos de identificação dos produtores de acordo com o critério - certificação orgânica (Grupo A: produtores certificados $\left(A_{1} \ldots A_{8}\right)$ e, Grupo B: produtores não certificados $\left(\mathrm{B}_{1} \ldots \mathrm{B}_{8}\right)$ ), visando maior facilidade no momento da avaliação das unidades de análise. O grupo A, é composto por oito (8) produtores orgânicos certificados com dois (2) ou três (3) anos de vinculação à OCS, estão em processo de obtenção do selo orgânico via OPAC (Quadro 15).

\section{Quadro 15 - Caracterização dos produtores do Grupo A.}

\begin{tabular}{|c|c|c|c|}
\hline Grupo & Características & $\begin{array}{c}\mathbf{N}^{\circ} \text { de } \\
\text { produtores }\end{array}$ & Localização \\
\hline Grupo A & $\begin{array}{l}\text { Produtores Orgânicos; } \\
\text { Certificação orgânica (Vinculação à OCS); } \\
\text { Em processo de obtenção do selo orgânico via OPAC; } \\
\text { Atividade produtiva: horticultura; } \\
\text { Marcada presença no mercado de orgânicos no DF: } \\
\text { Feiras e mercados institucionais. }\end{array}$ & 8 & $\begin{array}{c}\text { Bacia } \\
\text { Hidrográfica } \\
\text { do Rio } \\
\text { Maranhão }\end{array}$ \\
\hline
\end{tabular}

Fonte: Desenvolvido pelo autor.

A atividade produtiva do grupo A está voltada para a horticultura, com presença ativa no mercado de produtos orgânicos do DF participando de feiras orgânicas e mercados institucionais como o PAA (Quadro 15).

De acordo com os dados obtidos para a avaliação do nível de transição agroecológica, no grupo A, cinco dos oito produtores avaliados alcançaram o valor máximo total (18) no sub- 
nível 1 de transição agroecológica, indicando o cumprimento dos indicadores. Os três restantes têm dificuldades no cumprimento do indicador "praticas do preparo do solo", pois estão usando ainda aração e gradagem no seu sistema produtivo, isto contribuiu para gerar um valor total menor do sub-nível 1 de produção agroecológica, quando comparado o máximo possível $(17,6 / 18)$ (Tabela 1).

Tabela 1- Valores transição agroecológica grupo A de produtores rurais.

\begin{tabular}{|c|c|c|c|c|c|}
\hline \multirow[t]{2}{*}{ Produtor } & \multicolumn{3}{|c|}{$\begin{array}{l}\text { Valores dos Sub-Níveis de } \\
\text { Transição Agroecológica }\end{array}$} & \multirow{2}{*}{$\begin{array}{c}\text { Valor de Nível de } \\
\text { Transição Agroecológica } \\
\text { Total (TA) }\end{array}$} & \multirow{2}{*}{$\begin{array}{c}\text { Nível de } \\
\text { Transição } \\
\text { Agroecológica }\end{array}$} \\
\hline & 1 & 2 & 3 & & \\
\hline $\mathrm{A}_{1}$ & 18 & 24 & 33 & 75 & 3 \\
\hline $\mathrm{A}_{2}$ & 18 & 24 & 36 & 78 & 3 \\
\hline $\mathrm{A}_{3}$ & 18 & 26 & 42 & 86 & 3 \\
\hline $\mathrm{A}_{4}$ & 17 & 22 & 33 & 72 & 3 \\
\hline $\mathrm{A}_{5}$ & 17 & 22 & 33 & 72 & 3 \\
\hline $\mathrm{A}_{6}$ & 17 & 28 & 42 & 87 & 3 \\
\hline $\mathrm{A}_{7}$ & 18 & 28 & 42 & 88 & 3 \\
\hline $\mathrm{A}_{8}$ & 18 & 26 & 42 & 86 & 3 \\
\hline Média & 17,6 & 25 & 37,9 & 80,5 & 3 \\
\hline Máximo & 18 & 30 & 45 & 93 & 3 \\
\hline
\end{tabular}

Fonte: Dados de pesquisa, coletados entre os meses de Maço e Julho de 2014.

Quando avaliado o sub-nível 2 de transição agroecológica do grupo A, encontrou-se um valor médio total do sub-nível de vinte e cinco, valor abaixo do máximo possível (Tabela 1). Esta situação pôde ser explicada pela identificação de falhas, principalmente nos indicadores: i) Práticas de uso da biodiversidade funcional e de componentes da paisagem no manejo produtivo das culturas agrícolas; e ii) Eficiência no uso da energia e insumos baseados na reciclagem de nutrientes. O primeiro indicador evidenciou uma ineficiência no uso de cercas vivas ou cordões vegetados, sendo estes utilizados apenas com função de barreira, e não de forma produtiva e ecológica (quebra-vento, melífera e forrageira). No segundo indicador foi identificada a utilização ainda de insumos externos os quais estão sendo associados com insumos internos, atividade que poderia ser substituída pela utilização apenas de insumos internos oriundos da reciclagem de nutrientes (ex: adubação verde, esterco, silagem e compostagem) (FEISTAUER, 2012). 
O valor médio do sub-nível 3 de transição agroecológica para o grupo A, foi de 37,9, um valor abaixo do máximo valor para este sub-nível (45) (Tabela 1). Isto evidenciou a existência ainda de um déficit na integração da biodiversidade com os componentes: produção animal, agrícola e florestal (GLIESSMAN, 2000). O indicador que teve maior contribuição neste valor foi o referido à utilização de áreas de preservação permanente (APP) e reserva legal (RL), pois os produtores não incluem no seu sistema de produção agrícola estas áreas, argumentando que eles preferem preserva-las na sua totalidade. De acordo com Cardoso, et. al. (2007) o processo de transição agroecológica, como processo complexo que é, será desenvolvido de forma menos difícil quanto maior for o grau de articulação do agroecossistema com o produtor ou grupo de produtores associados, isto é, o manejo de plantas espontâneas e realização de práticas agroflorestais com a vegetação nativa, tudo em um marco sustentável. Contudo, não se deve desconhecer que todos os produtores dentro do grupo A (8/8) praticam na sua totalidade e de forma ampla as atividades do sistema orgânico de produção agrícola (BRASIL, 2003; IFOAM, 2014a).

O grupo $\mathrm{B}$, foi caracterizado como de produtores com sistemas de produção conduzidos sob práticas orgânicas, sem certificação como produtores orgânicos, mas encontram-se no processo de avaliação de conformidade na OCS da comunidade (Quadro 16).

\section{Quadro 16 - Caracterização dos produtores do Grupo B.}

\begin{tabular}{c|l|c|c}
\hline Grupo & \multicolumn{1}{|c|}{ Características } & \multicolumn{1}{c|}{\begin{tabular}{c}
\multicolumn{1}{c|}{$\mathbf{N}^{\circ}$ de } \\
produtores
\end{tabular}} & Localização \\
\hline \multirow{2}{*}{ Grupo B } & $\begin{array}{l}\text { Produtores orgânicos; } \\
\text { Em processo de certificação (avaliação de } \\
\text { conformidade pela OCS); } \\
\text { Atividade produtiva: horticultura; } \\
\begin{array}{l}\text { Pouca Presença no mercado de orgânicos no DF: } \\
\text { Feiras e mercados institucionais. Preço dos }\end{array}\end{array}$ & 4 & $\begin{array}{c}\text { Bacia } \\
\text { Hidrográfica } \\
\text { do Rio } \\
\text { Maranhão }\end{array}$ \\
\cline { 2 - 4 } & 4 & $\begin{array}{c}\text { Bacia } \\
\text { Hidrográfica } \\
\text { do Rio São } \\
\text { Bartolomeu }\end{array}$ \\
\hline
\end{tabular}

Fonte: Desenvolvido pelo autor.

Os produtores deste grupo, da mesma forma que os produtores do grupo A, mantem sua atividade produtiva voltada para a horticultura, mas sua participação no mercado de orgânicos está focada principalmente nas feiras orgânicas, salientando-se a presença do atravessador na cadeia. Uma pequena parte do grupo mantem relações comerciais com os mercados institucionais (PAA) (Quadro 16). 
Com os dados obtidos para a análise do nível de transição agroecológica, encontrou-se que o grupo B apresenta um valor em média para o sub-nível 1 de transição agroecológica de 16,38. Trata-se de um valor abaixo do valor máximo possível de 18 (Tabela 2). Isto está relacionado com os indicadores referentes a práticas de adubação e controle de pragas e doenças; e práticas de preparo e conservação do solo para os cultivos agrícolas. Destaca-se, que ainda os produtores deste grupo tenham reduzido o uso de insumos e defensivos sintéticos como medida necessária ao processo de certificação orgânica das propriedades rurais (MAPA, 2014e; BRASIL, 2003), em alguns casos, ainda persiste a utilização de adubos sintéticos, embora com notável redução da frequência de aplicação em alguns cultivos. Da mesma forma se evidenciou a utilização de defensivos sintéticos, mas associados a defensivos ecológicos e à promoção de inimigos naturais.

Tabela 2 - Valores Transição Agroecológica grupo B de produtores rurais.

\begin{tabular}{c|c|c|c|c|c}
\hline \multirow{2}{*}{ Produtor } & \multicolumn{3}{|c|}{$\begin{array}{c}\text { Valores dos Sub-Níveis de } \\
\text { Transição Agroecológica }\end{array}$} & $\begin{array}{c}\text { Valor de Nível de } \\
\text { Transição Agroecológica } \\
\text { Total (TA) }\end{array}$ & $\begin{array}{c}\text { Nível de } \\
\text { Transição } \\
\text { Agroecológica }\end{array}$ \\
\cline { 2 - 4 } & $\mathbf{1}$ & $\mathbf{2}$ & $\mathbf{3}$ & 62 & 2 \\
\hline $\mathrm{B}_{1}$ & 17 & 18 & 27 & 60 & 2 \\
\hline $\mathrm{B}_{2}$ & 16 & 20 & 24 & 62 & 2 \\
\hline $\mathrm{B}_{3}$ & 18 & 20 & 24 & 53 & 2 \\
\hline $\mathrm{B}_{4}$ & 16 & 16 & 21 & 60 & 2 \\
\hline $\mathrm{B}_{5}$ & 16 & 20 & 24 & 64 & 2 \\
\hline $\mathrm{B}_{6}$ & 18 & 22 & 24 & 57 & 2 \\
\hline $\mathrm{B}_{7}$ & 15 & 24 & 18 & 58 & $\mathbf{2}$ \\
\hline $\mathrm{B}_{8}$ & 15 & 22 & 21 & $\mathbf{5 9 , 5 0}$ & 2 \\
\hline Média & $\mathbf{1 6 , 3 8}$ & $\mathbf{2 0 , 2 5}$ & $\mathbf{2 2 , 8 8}$ & $\mathbf{6 2}$ & 2 \\
\hline Máximo & $\mathbf{1 8}$ & $\mathbf{3 0}$ & $\mathbf{4 5}$ & & 2 \\
\hline
\end{tabular}

Fonte: Dados de pesquisa, coletados entre os meses de Maço e Julho de 2014.

Quando feitas as análises do nível de transição agroecológica, observou-se que os valores dos sub-níveis 2 e 3 de transição agroecológica para o grupo $\mathrm{B}$, ficaram distantes e de forma expressiva do seu valor máximo. Assim, o valor médio dos sub-níveis 2 e 3 de transição agroecológica para o grupo B foi de 20,25 e 22,88 respetivamente (Tabela 2), situação que explicou-se através da análise de diversos indicadores, entre os de maior peso destacam-se os apresentados no Quadro 17. 
Quadro 17 - Identificação das falências nos indicadores dos sub-níveis 2 e 3 de transição agroecológica para o Grupo B.

\begin{tabular}{|c|c|c|c|}
\hline $\begin{array}{l}\text { SUB- } \\
\text { NÍVEL }\end{array}$ & INDICADOR & IDEAL & FALÊNCIAS \\
\hline \multirow[b]{2}{*}{2} & $\begin{array}{l}\text { Práticas de utilização de } \\
\text { insumos de base ecológica. }\end{array}$ & $\begin{array}{l}\text { Utiliza mais de três tipos de } \\
\text { insumos de base ecológica } \\
\text { em todas as áreas } \\
\text { produtivas. }\end{array}$ & $\begin{array}{lrr}\begin{array}{l}\text { Implantação } \\
\text { algumas }\end{array} & \text { só } \quad \text { em } \\
\text { produtivas. } & & \\
& & \end{array}$ \\
\hline & $\begin{array}{l}\text { Adoção de técnicas de } \\
\text { controle biológico de pragas e } \\
\text { doenças. }\end{array}$ & \begin{tabular}{l}
\multicolumn{4}{l}{ Utilizar mais de uma técnica } \\
ou agentes de controle \\
biológico em todas as áreas \\
produtivas, sendo uma \\
prática de rotina na \\
propriedade.
\end{tabular} & $\begin{array}{l}\text { Implementação apenas } \\
\text { em culturas isoladas. }\end{array}$ \\
\hline \multirow{4}{*}{3} & $\begin{array}{l}\text { Práticas de uso da } \\
\text { biodiversidade funcional e de } \\
\text { componentes da paisagem no } \\
\text { manejo produtivo. }\end{array}$ & $\begin{array}{l}\text { Utilizar a prática do aumento } \\
\text { da biodiversidade funcional } \\
\text { em todos os cultivos e áreas. }\end{array}$ & $\begin{array}{l}\text { Implantação só em } \\
\text { algumas culturas, } \\
\text { apenas com função de } \\
\text { barreira vegetal. }\end{array}$ \\
\hline & $\begin{array}{l}\text { Produção de sementes } \\
\text { próprias (ou mudas). }\end{array}$ & $\begin{array}{l}\text { Produzir mais de três tipos } \\
\text { de sementes próprias ou } \\
\text { crioulas. }\end{array}$ & 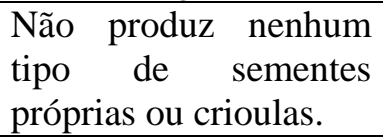 \\
\hline & $\begin{array}{l}\text { Utilização das áreas de APP e } \\
\text { de RL como parte do sistema } \\
\text { de produção agrícola da } \\
\text { unidade produtiva, de acordo } \\
\text { com a legislação ambiental. }\end{array}$ & $\begin{array}{l}\text { Apresentar as áreas de APP } \\
\text { e de RL com a vegetação } \\
\text { nativa predominante, com } \\
\text { utilização no sistema } \\
\text { produtivo da propriedade. }\end{array}$ & $\begin{array}{l}\text { Apresenta as áreas de } \\
\text { APP e de RL com a } \\
\text { vegetação nativa em } \\
\text { processo } \\
\text { recuperação de } \\
\text { regeneração, entretanto } \\
\text { não as utiliza no } \\
\text { sistema produtivo da } \\
\text { propriedade. }\end{array}$ \\
\hline & $\begin{array}{l}\text { Filiação a entidades } \\
\text { associativas ou cooperativas. }\end{array}$ & $\begin{array}{lrr}\text { É filiado na associação local } \\
\text { da comunidade e em } \\
\text { cooperativas locais } & \text { ou } \\
\text { regionais } & & \text { como } \\
\text { representante e } & \text { com } \\
\text { participação ativa. } & \\
\end{array}$ & $\begin{array}{l}\text { Não é filiado a } \\
\text { entidades cooperativas } \\
\text { ou associativas. }\end{array}$ \\
\hline
\end{tabular}

Fonte: Desenvolvido pelo autor.

Os produtores pertencentes ao grupo B, estão implantando as técnicas produtivas próprias dos sistemas orgânicos com bases agroecológicas de forma parcial (Quadro 17), o que influencia os baixos valores médios dos sub-níveis 2 e 3 de transição agroecológica. Salienta-se que o indicador que faz referencia à filiação dos produtores a entidades associativas ou cooperativas, evidencia um fraco interesse por parte dos produtores de participar nestes grupos sociais.

Quando comparadas as médias dos valores dos sub-níveis de transição agroecológica dos dois grupos, o grupo A expôs significativos valores superiores nos sub-níveis 2 e 3 de 
transição agroecológica (Tabela 3), evidenciando que a as propriedades pertencentes ao grupo A, estão avançando de forma positiva e efetiva no redesenho dos componentes do agroecossistema. A totalidade dos produtores formadores deste grupo pode ser enquadrada no terceiro nível de transição agroecológica denominado de redesenho dos agroecossistemas tendo ultrapassado os dois primeiros sub-níveis de transição agroecológica, com um valor médio do nível de transição agroecológica total (TA) de 80,5 sobre o máximo de 93 (Tabela 3).

Tabela 3 - Valores Médios da Transição Agroecológica dos grupos de produtores rurais. A e B.

\begin{tabular}{|c|c|c|c|c|c|}
\hline \multirow[t]{2}{*}{ Produtor } & \multicolumn{3}{|c|}{$\begin{array}{l}\text { Valores dos Sub-Níveis de } \\
\text { Transição Agroecológica }\end{array}$} & \multirow{2}{*}{$\begin{array}{c}\text { Valor de Nível de } \\
\text { Transiçãa Agroecológica } \\
\text { Total (TA) }\end{array}$} & \multirow{2}{*}{$\begin{array}{c}\text { Nível de } \\
\text { Transição } \\
\text { Agroecológica }\end{array}$} \\
\hline & 1 & 2 & 3 & & \\
\hline $\mathbf{A}$ & 17,6 & 25 & 37,9 & 80,5 & 3 \\
\hline $\mathbf{B}$ & 16,38 & 20,25 & 22,88 & 59,5 & 2 \\
\hline Máximo & 18 & 30 & 45 & 93 & - \\
\hline $\begin{array}{c}* \text { Significância } \\
\text { (Grupo } \\
\text { A/Grupo B) }\end{array}$ & Não Sign. & Sign. & Sign. & Sign. & - \\
\hline
\end{tabular}

"sign.": significativo e "Não Sign.”: não significativo de acordo com a comparação das médias do teste $t$-student em nível de significância de 5\% de erro.

Fonte: Desenvolvido pelo autor.

Para Glissman (2000) o terceiro nível de transição agroecológica é mais complexo, caracterizado pelo redesenho dos agroecosistemas visando um funcionamento harmônico e integrativo do novo conjunto de processos ecológicos. Bem que os produtores pertencentes ao grupo A terem cumprido com maioria dos indicadores dos sub-níveis 1 e 2 de transição agroecológica, ainda deverão ser ajustadas algumas das práticas alternativas próprias da produção agroecológica (Quadro 18). 


\section{Quadro 18 - Identificação das falhas nos indicadores do sub-nível 3 de transição agroecológica para o Grupo A.}

\begin{tabular}{|c|c|c|c|}
\hline $\begin{array}{l}\text { SUB- } \\
\text { NÍVEL }\end{array}$ & INDICADOR & IDEAL & FALHA \\
\hline \multirow{3}{*}{3} & $\begin{array}{l}\text { Produção de sementes } \\
\text { próprias (ou mudas). }\end{array}$ & $\begin{array}{l}\text { Produzir mais de três tipos } \\
\text { de sementes próprias ou } \\
\text { crioulas. }\end{array}$ & $\begin{array}{l}\text { Produz apenas três tipos de } \\
\text { sementes próprias para as } \\
\text { culturas principais ou } \\
\text { comerciais. }\end{array}$ \\
\hline & $\begin{array}{l}\text { Práticas de uso da } \\
\text { biodiversidade funcional e } \\
\text { de componentes da } \\
\text { paisagem no manejo } \\
\text { produtivo. }\end{array}$ & $\begin{array}{l}\text { Utilizar a prática do } \\
\text { aumento da biodiversidade } \\
\text { funcional em todos os } \\
\text { cultivos e áreas }\end{array}$ & $\begin{array}{l}\text { Utiliza a prática de uso da } \\
\text { biodiversidade funcional } \\
\text { apenas nos } \\
\text { principais. }\end{array}$ \\
\hline & $\begin{array}{l}\text { Utilização das áreas de } \\
\text { APP e de RL como parte } \\
\text { do sistema de produção } \\
\text { agrícola da propriedade } \\
\text { produtiva, de acordo com a } \\
\text { legislação ambiental. }\end{array}$ & $\begin{array}{l}\text { Apresentar as áreas de APP } \\
\text { e de RL com a vegetação } \\
\text { nativa predominante, com } \\
\text { utilização no sistema } \\
\text { produtivo da propriedade. }\end{array}$ & $\begin{array}{l}\text { Apresenta as áreas de APP e } \\
\text { de RL com a vegetação } \\
\text { nativa em processo de } \\
\text { recuperação e regeneração, } \\
\text { entretanto não as utiliza no } \\
\text { sistema produtivo da } \\
\text { propriedade. }\end{array}$ \\
\hline
\end{tabular}

Fonte: Desenvolvido pelo autor

Cabe ressaltar que as dificuldades apresentadas nas unidades produtivas pertencentes ao Grupo A vem sendo minimizadas pelo fato deque o grupo de produtores são parte integrante e ativa da ASTRAF, entidade que promove capacitações técnicas, contribui no intercambio de conhecimento técnico e tradicional entre os produtores, gera melhor planejamento da produção possibilitando atingir volumes mais altos de produção, alcançar uma maior variedade de produtos e um maior poder de negociação.

Mesmo ainda tendo-se enquadrado no nível 2 de transição agroecológica denominado de substituição de insumos sintéticos por orgânicos e implementação de práticas alternativas, os produtores do grupo B alcançaram um valor médio de TA para este nível de 59,5 próximo do máximo de 62 (Tabela 3).

O fato de que o grupo B não tenha ultrapasso o nível 2 de transição agroecológica é claramente identificado pela deficiência no cumprimento principalmente de dois parâmetros: substituição definitiva de insumos e práticas intensivas por práticas agroecológicas alternativas, encontrando-se com uma ainda persiste utilização de adubos sintéticos e de práticas agrícolas convencionais, situação que deverá ser voltada para uma integração dos ecossistemas com as práticas agroecológicas de produção (GLISSMAN, 2000); e o baixo nível de participação nas entidades associativas da comunidade, comprometimento a 
sustentabilidade do sistema agroecológico, o qual de acordo com Moreira (2012) significa, entre outras cosas, coesão entre o manejo da propriedade e sua organização interna com o meio externo, em termos tecnológicos, mercadológicos, políticos e organizacionais na procura da sustentabilidade localmente construída.

\subsubsection{Avaliação da aderência à legislação ambiental.}

Com o intuito de apresentar de forma clara os resultados levou-se em conta as unidades de analise: Conhecimento da legislação ambiental e Adequação à legislação ambiental. Isto permitiu uma melhor apresentação tanto dos dados do registro dos pontos geográficos que delimitam as propriedades estudadas, quanto dos dados obtidos por meio da aplicação dos formulários (Apêndice B) para a avaliação da aderência à legislação ambiental.

Unidade de analise: Conhecimento da legislação ambiental.

A totalidade dos produtores do grupo A não possui a RL averbada e nunca tentaram fazer a diligencia de averbação, da mesma forma não possui licenciamento ambiental (LAU) da propriedade (Tabela 4). Os oito produtores pertencentes ao grupo A, não conhecem as delimitação que consideram as áreas de APP nas zonas rurais ou urbanas, nem conhecem o regime da sua proteção, e a maioria deles (6/8) não sabem qual é o percentual de RL necessário para a propriedade (Tabela 4) de acordo com a legislação (BRASIL, 2012). Apenas dois produtores do grupo A souberam responder corretamente qual tinha que ser a quantidade de área de RL de acordo com a legislação na sua propriedade.

Tabela 4 - Questões sobre legislação ambiental nos dois grupos de produtores avaliados: Grupo A e Grupo B.

\begin{tabular}{|l|l|l|l|l|}
\hline \multirow{2}{*}{\multicolumn{1}{c|}{ Questões }} & \multicolumn{3}{c|}{ Grupo de produtores } \\
\cline { 2 - 5 } & \multicolumn{2}{|c|}{ Grupo A } & \multicolumn{2}{c|}{ Grupo B } \\
\cline { 2 - 5 } & Sim & Não & Sim & Não \\
\cline { 2 - 5 } & \multicolumn{4}{|c}{$\mathrm{N}^{\circ}$ de produtores que } \\
responderam as perguntas
\end{tabular}




\begin{tabular}{|c|c|c|c|c|}
\hline \multirow{4}{*}{ Questões } & \multicolumn{4}{|c|}{ Grupo de produtores } \\
\hline & \multicolumn{2}{|c|}{ Grupo A } & \multicolumn{2}{|c|}{ Grupo B } \\
\hline & Sim & Não & Sim & Não \\
\hline & \multicolumn{4}{|c|}{$\begin{array}{l}\mathrm{N}^{\circ} \text { de produtores que } \\
\text { responderam as perguntas }\end{array}$} \\
\hline Alguma vez tentou fazer a diligencia de averbação da RL? & - & 8 & - & 8 \\
\hline $\begin{array}{l}\text { Conhece como deve fazer-se a delimitação das áreas de } \\
\text { APP na propriedade? }\end{array}$ & - & 8 & - & 8 \\
\hline Conhece o regime de proteção das áreas APP? & - & 8 & - & 8 \\
\hline Qual é o percentual de RL necessário para a propriedade? & 2 & 6 & - & 8 \\
\hline
\end{tabular}

Fonte: Desenvolvido pelo autor.

Quando feito a analise dos dados sobre o conhecimento da legislação ambiental do grupo $\mathrm{B}$, encontrou-se um perfil similar, pois nenhum dos produtores tem sequer, um conhecimento básico da legislação (Tabela 4).

A maior parte dos produtores pertencentes aos dois grupos pesquisados (A e B) não respondeu corretamente nenhuma das questões apresentadas. No momento em que foram efetuadas as entrevistas, entretanto, a grande maioria dos produtores de ambos os grupos, declarou que existe uma necessidade de proteger e preservar a mata nativa nas suas áreas e no entorno. Os agricultores, declararam também que essa necessidade de preservação, além de ser um sentimento pessoal é também uma aderência à exigência de lei, embora não tiveram como responder a quantidade de área de RL e de APP que deveria existir nas suas propriedades, de acordo com a legislação. Neste sentido, Godoy et. al. (2009) expõe que o fato dos agricultores não conhecerem os termos e a própria legislação não implica que eles sejam alheios à preservação do meio ambiente, mas a falta deste conhecimento os torna expostos a multas e penalidades.

O amplo desconhecimento da legislação ambiental encontrado nos grupos de produtores avaliados pode-se relacionar com frequente surgimento de alterações e revogações à legislação (Quadro 1), além da recente publicação e entrada em vigor do Novo Código Florestal Lei $\mathrm{N}^{\mathrm{0}}$ 12.651, de 2012, que faz com que a grande maioria dos produtores entrevistados argumentem que não sabem qual é a legislação adequada para eles.

"Nos temos trabalho de mais na horta, e não temos o tempo para estudar a legislação, ela é muito extensa e além enrolada, eu acho que nenhum de nós conhece a lei ambiental, mas sim protegemos a mata nativa..." Produtor $\mathrm{A}_{1}$. 
"Não sabia que eu tinha que cumprir com a legislação ambiental, até porque tenho muita pouca terra, esse negocio da lei ambiental tem muita burocracia, eu não entendo como funciona..." Produtor $\mathrm{B}_{2}$.

O padrão de desconhecimento da legislação vigente, encontrado no estudo, foi salientado por Feistauer (2012) que argumentou que a maioria dos produtores avaliados na sua pesquisa conhecia o porcentual correto de área de RL na Amazônia Legal, mas até a publicação da medida provisória $\mathrm{n}^{\circ} 2.166$ de 24 de agosto de 2001 que aumentou o percentual de RL. De acordo com Godoy, et. al. (2009) e Godoy e Wizniewsky (2013), muitos dos problemas da gestão ambiental no Brasil, decorrem de um parcial conhecimento ou desconhecimento sobre as normativas existentes e da falta de informação, seja no sentido da legislação ou das possibilidades de manejo desta, o que faz com que a maioria das propriedades rurais familiares esteja em desacordo com a lei, tornando os agricultores passíveis de multas e penalidade.

Porém, um dos parâmetros indispensáveis para o desenvolvimento sustentável, reconhecido por Godoy e Wizniewsky (2013) é o acesso à informação e a educação ambiental por parte de todos os indivíduos e setores da sociedade, visando atingir a sustentabilidade ambiental desejada, valorizando os agricultores, promovendo o desenvolvimento rural, assim como a qualidade de vida das famílias do ambiente rural.

Unidade de analise: Adequação à legislação ambiental.

Num primeiro momento, levando em conta as respostas dos produtores em relação às questões sobre conhecimento da legislação ambiental (Tabela 4), encontrou-se que em todos os casos, tanto os produtores pertencentes ao grupo A (8/8), quanto os pertencentes ao grupo B (8/8), não cumpriram com o disposto pela legislação no que diz respeito ao licenciamento ambiental (BRASIL, 1997), cuja necessidade adota o caráter de obrigatório para qualquer propriedade rural que para efeitos da legislação é considerada como empreendimento potencialmente poluidor (BRASIL, 1998; BRASIL, 1997).

Já quando avaliadas as áreas de RL e APP das propriedades, os perímetros tiveram que ser retificados considerando os indícios de ocupação de fato e as faixas de domínio de rodovias, para o cálculo correto da porcentagem de reserva legal obrigatória. Os perímetros das propriedades constituem imóveis abaixo de 4 módulos fiscais (abaixo de 20 hectares) e 
todos são indicados como lotes de assentamento de reforma agrária, com exceção de dois que são indicados como propriedades, uma delas com área maior que 20 hectares (Tabela 5). Daí, a necessidade de definir a RL em termos de assentamentos de reforma agraria. De acordo com a legislação, as áreas de reserva legal correspondem, via de regra, a 20\% da área dos imóveis rurais que não estejam localizados na Amazônia legal conforme $\S 1^{\circ}$ do artigo 12 do Novo Código Florestal lei 12.651 de 2012:

[...] Em caso de fracionamento do imóvel rural, a qualquer título, inclusive para assentamentos pelo Programa de Reforma Agrária, será considerada, para fins do disposto do caput, a área do imóvel antes do fracionamento.

Assim por força de lei, foi necessária a definição da RL considerando o imóvel matriz que dê origem ao assentamento. A Figura 9 indica os dos dois assentamentos identificados como Chapadinha (circulado em vermelho) e Pequeno William (circulado em azul) nos quais se encontram alocadas a maioria das propriedades rurais analisadas (14/16); da mesma forma encontra-se indicada a alocação das duas propriedades restantes (circuladas em verde).

\section{Figura 10 - Indicação das áreas de reforma agraria e dos perímetros indicados como propriedades}

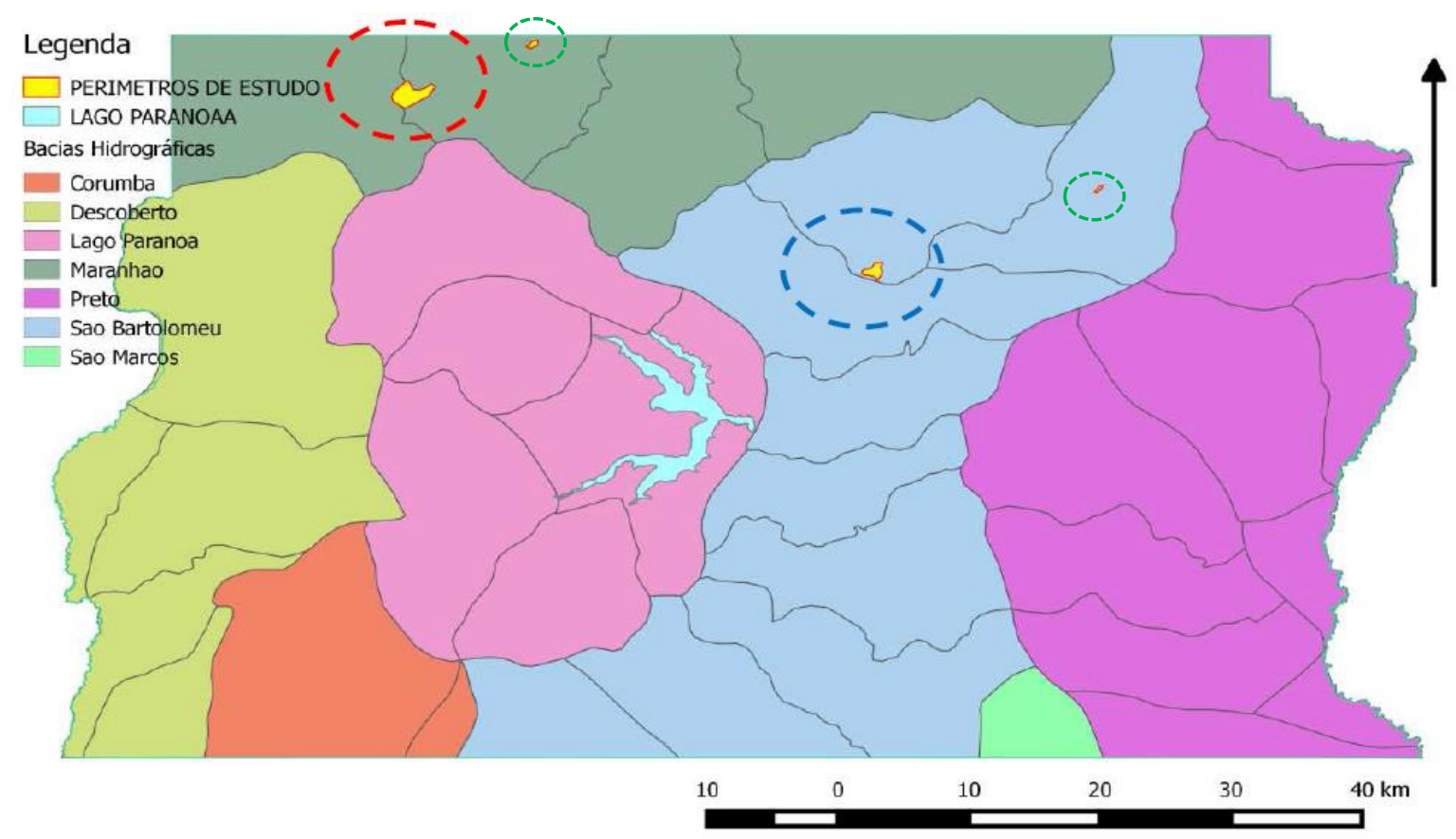

Fonte: COOPERAÇÃO TÉCNICA IBRAM - UNB. 
Houve, contudo, a necessidade de retificar o perímetro indicado como assentamento Chapadinha, considerando as informações fundiárias, conformando-o assim de acordo com o limite da Fazenda Palmas, de propriedade da União. Considerou-se também, a informalidade da ocupação, classificada como acampamento e não como assentamento ${ }^{1}$. No polígono Vermelho da Figura 10 indica-se o acampamento Chapadinha, para o qual deveria ser definida a RL da área maior (Polígono verde) visando averiguar a regularidade ambiental do futuro assentamento e dos lotes.

\section{Figura 11 - Situação fundaria que envolve o acampamento Chapadinha.}

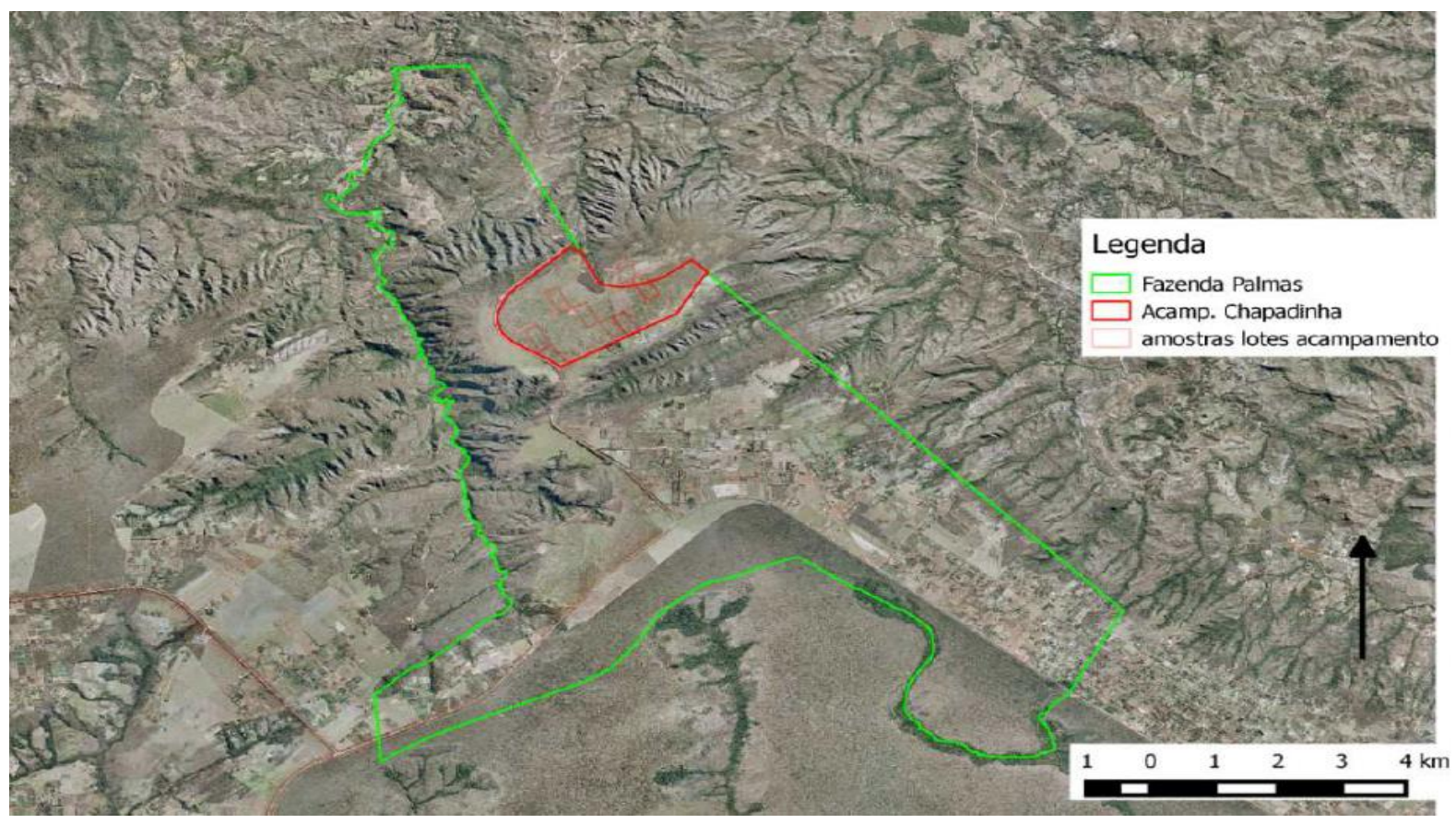

Fonte: COOPERAÇÃO TÉCNICA IBRAM - UNB.

Considerando que as ocupações possuíam a dimensão desde antes de 22 de Julho de 2008, no entanto, não há situação irregular visto que a reserva legal nestes casos será configurada pela vegetação existente à esta data (marco legal), conforme no Novo Código Florestal Lei 12.651 de 2012, pelo artigo 67, que assim determina:

[...] Artigo 67. Nos imóveis rurais que detinham, em 22 de julho de 2008, área de até 4 (quatro) módulos fiscais e que possuam remanescente de vegetação nativa em percentuais inferiores ao previsto

\footnotetext{
${ }^{1}$ Conforme informação verbal proferida no Instituto Nacional de Colonização e Reforma Agrária (INCRA) pela servidora Dulce Amaral, em Brasília, em 17 de Junho de 2014.
} 
no art. 12, a Reserva Legal será constituída com a área ocupada com a vegetação nativa existente em 22 de julho de 2008, vedadas novas conversões para uso alternativo do solo.

Portanto, para a realidade imediata destes produtores, não existe obrigação concreta de recuperação de vegetação nativa para constituição de RL pelos acampados sinalizados em amarelo e vermelho (Figura 11), há somente, quando dada a formalização do assentamento, a corresponsabilidade entre a Entidade de Reforma Agraria e os assentamentos, na recuperação do trecho de APP degradado (Sinalizado em laranja na Figura 11).

Figura 12 - Feições de interesse ambiental no perímetro do acampamento Chapadinha.

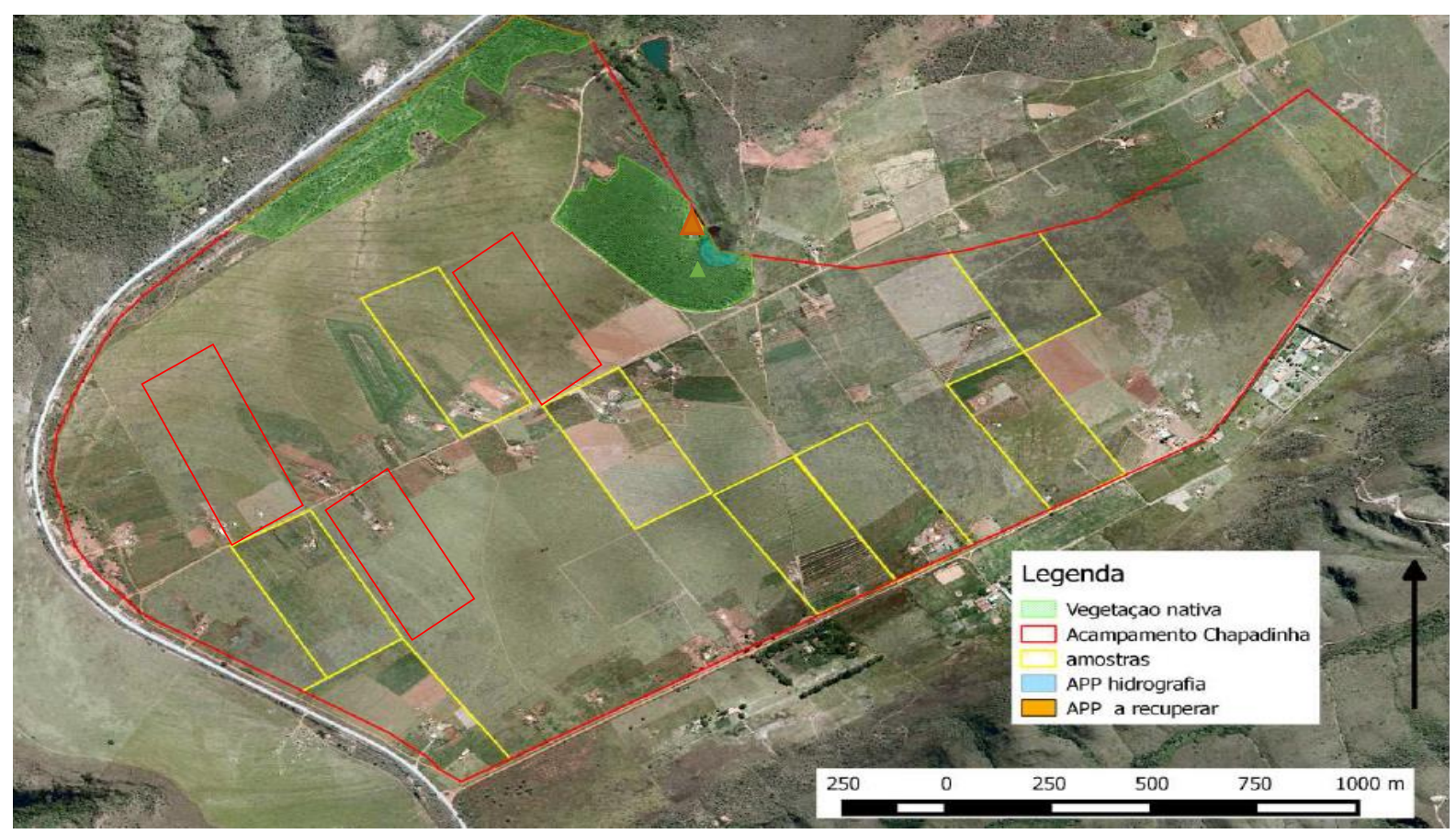

Fonte: COOPERAÇÃO TÉCNICA IBRAM - UNB

Dentro do perímetro apresentado do acampamento Chapadinha (Figura 11), encontram-se 11 propriedades, das quais 8 são pertencentes ao grupo A de produtores avaliados (sinalizados em amarelo), as outras 3 feições correspondem ao grupo B (sinalizados em vermelho).

Na tabela 5 resume-se o quantitativo das áreas totais das propriedades avaliadas, assim como suas áreas de RL e de APP necessárias de acordo com os mínimos exigidos pela legislação ambiental brasileira (BRASIL, 2012), suas áreas conservadas, a quantidade a recuperar de cada uma e a área de vegetação nativa excedente. Foram geradas as faixas de 
área de APP na projeção de 30 metros (conforme o NOVO CÓDIGO FLORESTAL LEI Nº 12.651, de 2012) em função da interferência nos imóveis da hidrografia indicada pela cartografia oficial do DF.

Tabela 5 - Quantitativo das áreas de preservação permanente (APP) e de reserva legal (RL) em propriedades rurais pertencentes a dois grupos de produtores orgânicos: Grupo A e Grupo B.

\begin{tabular}{|c|c|c|c|c|c|c|c|c|c|c|c|c|}
\hline Grupo & Produtor & Subgrupo & $\begin{array}{c}\text { Área da } \\
\text { propriedade } \\
\text { (ha) }\end{array}$ & $\begin{array}{l}\text { Área de } \\
\text { APP de } \\
\text { hidrografia } \\
\text { necessária } \\
\text { (ha) }\end{array}$ & $\begin{array}{l}\text { Área de } \\
\text { APP } \\
\text { conservada } \\
\text { (ha) }\end{array}$ & $\begin{array}{c}\text { Área de } \\
\text { APP } \\
\text { conservada } \\
(\%)\end{array}$ & $\begin{array}{l}\text { Área de } \\
\text { APP a } \\
\text { recuperar } \\
\text { (ha) }\end{array}$ & $\begin{array}{l}\text { RL } 20 \% \\
\text { obrigatória } \\
\text { (há) }\end{array}$ & $\begin{array}{c}\text { RL } \\
\text { Conservada } \\
\text { (ha) }\end{array}$ & $\begin{array}{c}\text { RL } \\
\text { Conservada } \\
(\%)\end{array}$ & $\begin{array}{c}\text { RL a } \\
\text { recuperar } \\
\text { (ha) }\end{array}$ & $\begin{array}{c}\text { Vegetação } \\
\text { nativa } \\
\text { excedente } \\
\text { (ha) }\end{array}$ \\
\hline A & $\begin{array}{l}A_{1} ; A_{2} ; \\
A_{3} ; A_{4} ; \\
A_{5} ; A_{6} ; \\
A_{7} ; A_{8} ;\end{array}$ & $\begin{array}{c}\text { Acampamento } \\
\text { Chapadinha } \\
\text { porção }\end{array}$ & \multirow[t]{2}{*}{395,81} & \multirow[t]{2}{*}{0,62} & \multirow[t]{2}{*}{0,54} & \multirow[t]{2}{*}{86,62} & \multirow[t]{2}{*}{0,08} & \multirow[t]{2}{*}{$* 78,96$} & \multirow[t]{2}{*}{$* 23,26$} & \multirow[t]{2}{*}{$* 29,45$} & \multirow[t]{2}{*}{$* 55,71$} & \multirow[t]{2}{*}{0,00} \\
\hline \multirow{4}{*}{ B } & $\begin{array}{c}\mathrm{B}_{1} ; \mathrm{B}_{2} ; \\
\mathrm{B}_{3}\end{array}$ & Palmas & & & & & & & & & & \\
\hline & $\begin{array}{c}\mathrm{B}_{4} ; \mathrm{B}_{5} ; \\
\mathrm{B}_{6}\end{array}$ & $\begin{array}{c}\text { Assentamento } \\
\text { Pequeno } \\
\text { William }\end{array}$ & 129,12 & \multicolumn{4}{|c|}{ Não Aplica } & 25,82 & 25,82 & 100 & 0,00 & 83,79 \\
\hline & $\mathrm{B}_{7}$ & $\mathrm{~B}_{7}$ & 15,49 & 0,68 & 0,68 & 100 & 0,00 & 3,1 & 3,1 & 100 & 0,00 & 3,79 \\
\hline & $B_{8}$ & $B_{8}$ & 32,99 & 10,16 & 8,18 & 80,52 & 1,98 & 6,6 & 0,00 & 0,00 & 6,6 & 0,00 \\
\hline
\end{tabular}

* Não aplica conforme no Novo Código Florestal Lei 12.651 de 2012, pelo artigo 67.

Fonte: COOPERAÇÃO TÉCNICA IBRAM - UNB.

De ocorrer a corresponsabilidade entre a Entidade de Reforma Agraria e o futuro assentamento Chapadinha, nota-se que a percentagem de área de APP de hidrografia conservada atingiu só o 86,62\% respeito à área APP de hidrografia necessária, ficando com um déficit de 0,08 hectares o qual deverá ser recuperado (Tabela 5). De acordo com o exposto, a totalidade das propriedades que conformam o grupo A (8/8) enquadra-se na legislação ambiental no que diz respeito ao percentual necessário ou mínimo exigido de áreas RL, más mantem um déficit de área de APP que deverá ser recuperado no momento da formalização como assentamento. Cabe ressaltar que as feições ou propriedades avaliadas no acampamento Chapadinha foram ocupadas quando já tinha ocorrido o desmatado por parte da cultura da soja.

“... ai quando nos chegamos toda a área esteva desmatada, acho que existiu uma grande produção de soja na área toda, desde há 9 anos nós temos trabalhado para recuperar e conservar a mata, agora você pode olhar que tem melhorado muito”. Produtor $\mathrm{A}_{3}$. 
No caso do assentamento Pequeno William, que foi fundado em 2010 (DURÃES, 2014), foi avaliada só a área de RL, pois não se aplica o que abrange a áreas de APP de hidrografia, devido à não interferência da hidrografia indicada pela cartografia oficial do DF nos imóveis pesquisados. Dentro do perímetro apresentado do assentamento Pequeno William (Figura 12), encontram-se inseridas 3 propriedades do grupo B de produtores avaliados, sinalizados em amarelo. Em relação à área de RL do assentamento, a vegetação nativa engloba grande extensão de área, conforme pode ser observado na Figura 12, de acordo com os pontos geográficos que delimitam as propriedades e a declaração dos produtores pertencentes ao assentamento.

Figura 13 - Feições de interesse ambiental do Perímetro assentamento Pequeno William.

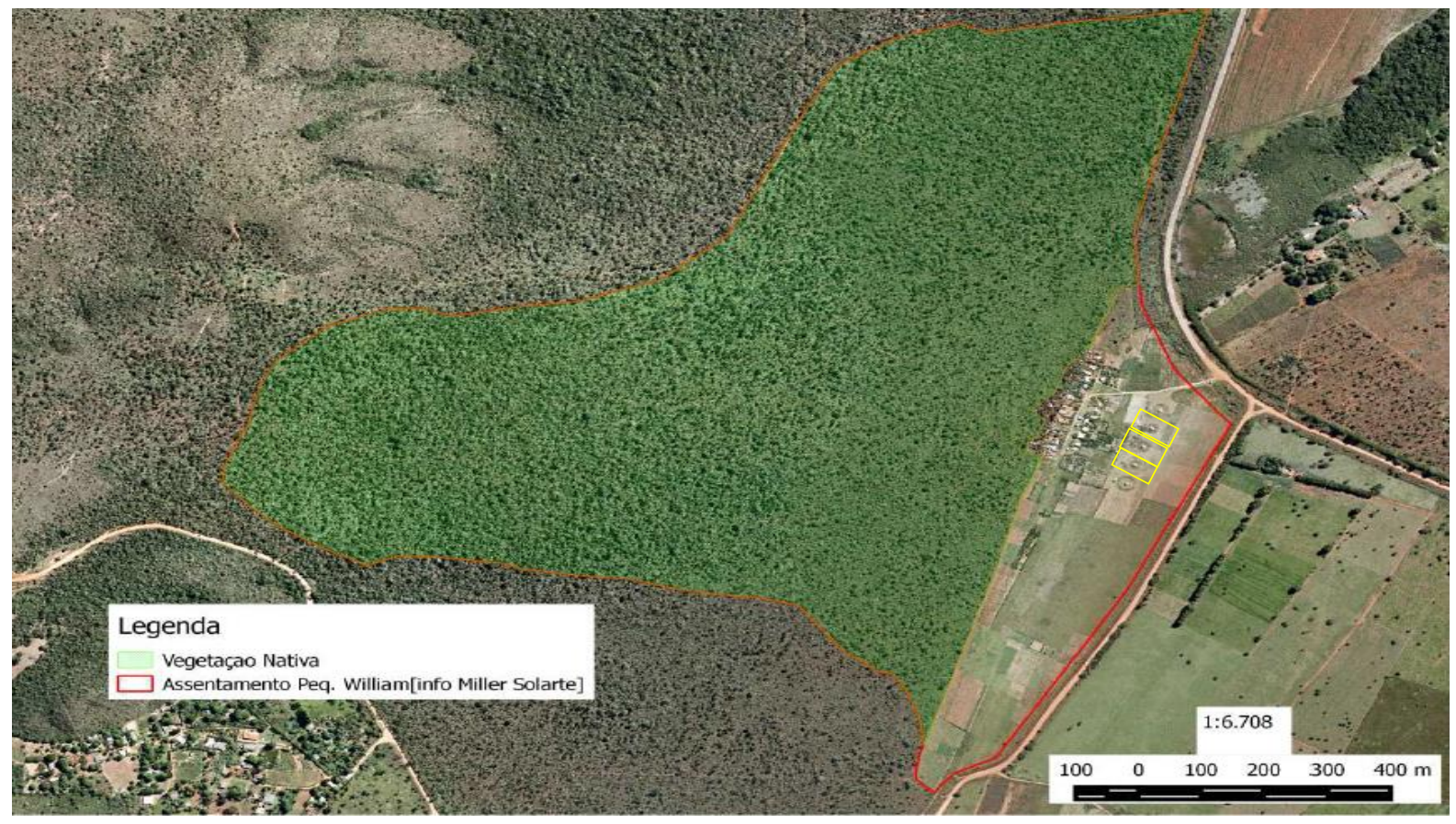

Fonte: COOPERAÇÃO TÉCNICA IBRAM - UNB

Cabe destacar, que neste caso a extensão de vegetação nativa teve que ser considerada na configuração do imóvel rural que abarca a área do assentamento, em obediência ao artigo $12 \S 1^{\circ}$ do Novo Código Florestal Lei 12.651 de 2012 citado anteriormente. Segunda a legislação, o assentamento deveria responder por 25,82 hectares de RL, área que de acordo com os dados obtidos do assentamento está sendo 100\% conservada, apresentando 83,79 hectares de vegetação nativa excedente (Tabela 5). Com isto pode-se argumentar que os 3 produtores do grupo B, inseridos no assentamento Pequeno William, encontram-se 
enquadrados na legislação ambiental no que diz respeito ao percentual necessário ou mínimo exigido de áreas RL, reconhecendo que não se aplica para eles o referente à delimitação das áreas de APP de hidrografia.

Quanto as propriedades particulares, pertencentes também ao grupo B de produtores rurais, foi realizada a retificação dos perímetros apresentados (produtores $\mathrm{B}_{7}$ e $\mathrm{B}_{8}$ ), observando a hidrografia oficial e a faixa de domínio da rodovia que margeia a propriedade. $\mathrm{Da}$ analise do perímetro apresentado como do produtor $\mathrm{B}_{7}$, chegou-se à configuração de uso de solo ilustrada na Figura 13.

\section{Figura 143 - Feições ambientais de interesse do imóvel $B_{7}$.}

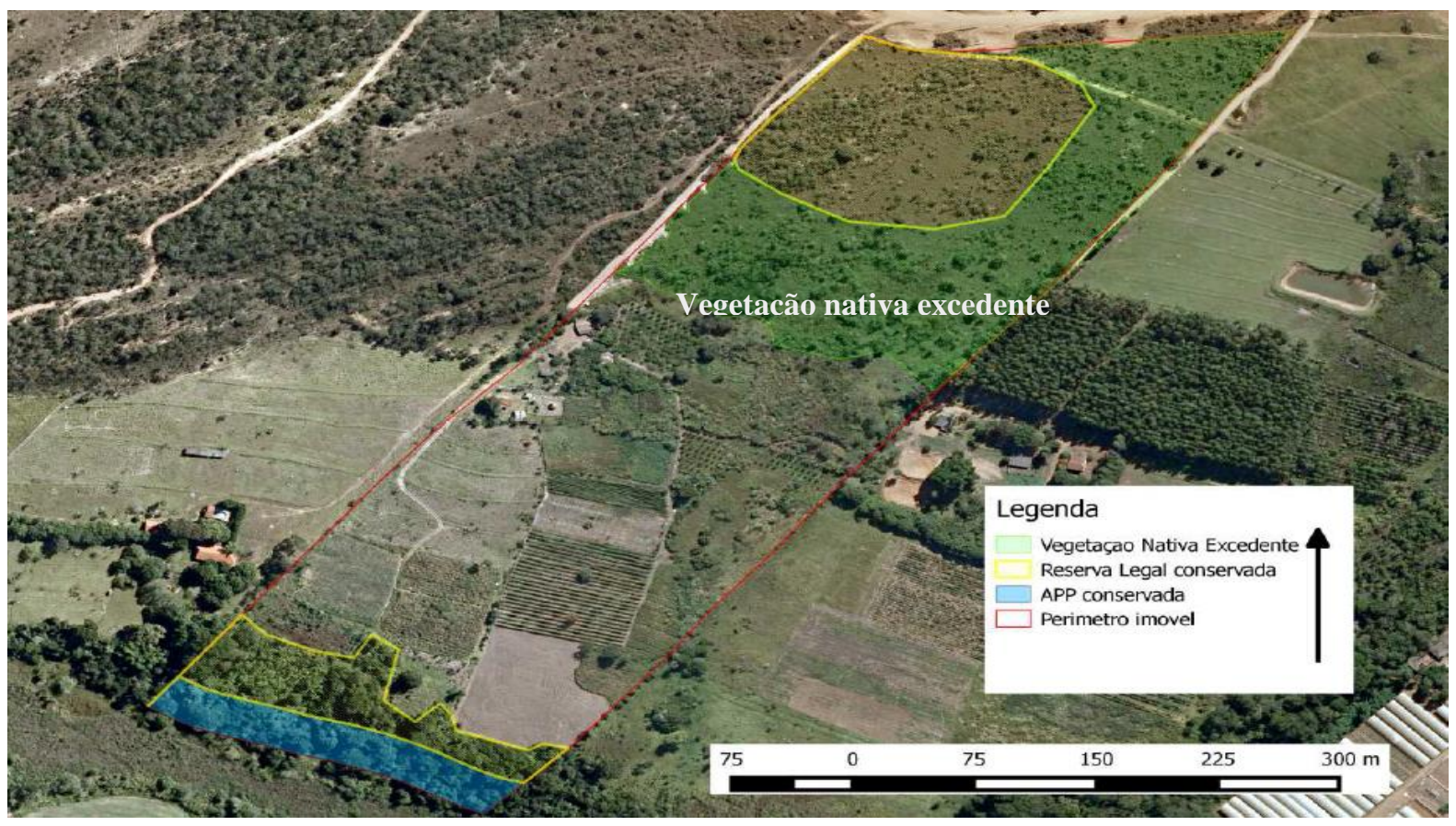

Fonte: COOPERAÇÃO TÉCNICA IBRAM - UNB

Destaca-se a existência de vegetação nativa (sombreada de verde) que atende satisfatoriamente a conservação de área de APP e atende a proporção necessária de RL (Figura 13).

Assim existem 3,79 hectares de vegetação nativa excedente (Tabela 5) que podem ser observadas na parte superior da Figura 13, a ser considerado como ativo ambiental, que poderia ser negociado com interessados em compensar passivos ambientais. De acordo com o quantitativo das áreas de RL e APP de hidrografia (Tabela 5), a propriedade $\mathrm{B}_{7}$ enquadre-se dentro da legislação ambiental atingindo tanto o percentual necessário ou mínimo exigido de 
área RL para a propriedade de 3,10 hectares, quanto o percentual necessário ou mínimo exigido de área de APP que para o caso é de 0,68 hectares.

Finalmente, da análise do perímetro apresentado como do produtor $\mathrm{B}_{8}$, chegou-se à configuração de uso de solo ilustrada na Figura 14.

\section{Figura 154 - Feições ambientais de interesse do imóvel $B_{8}$.}

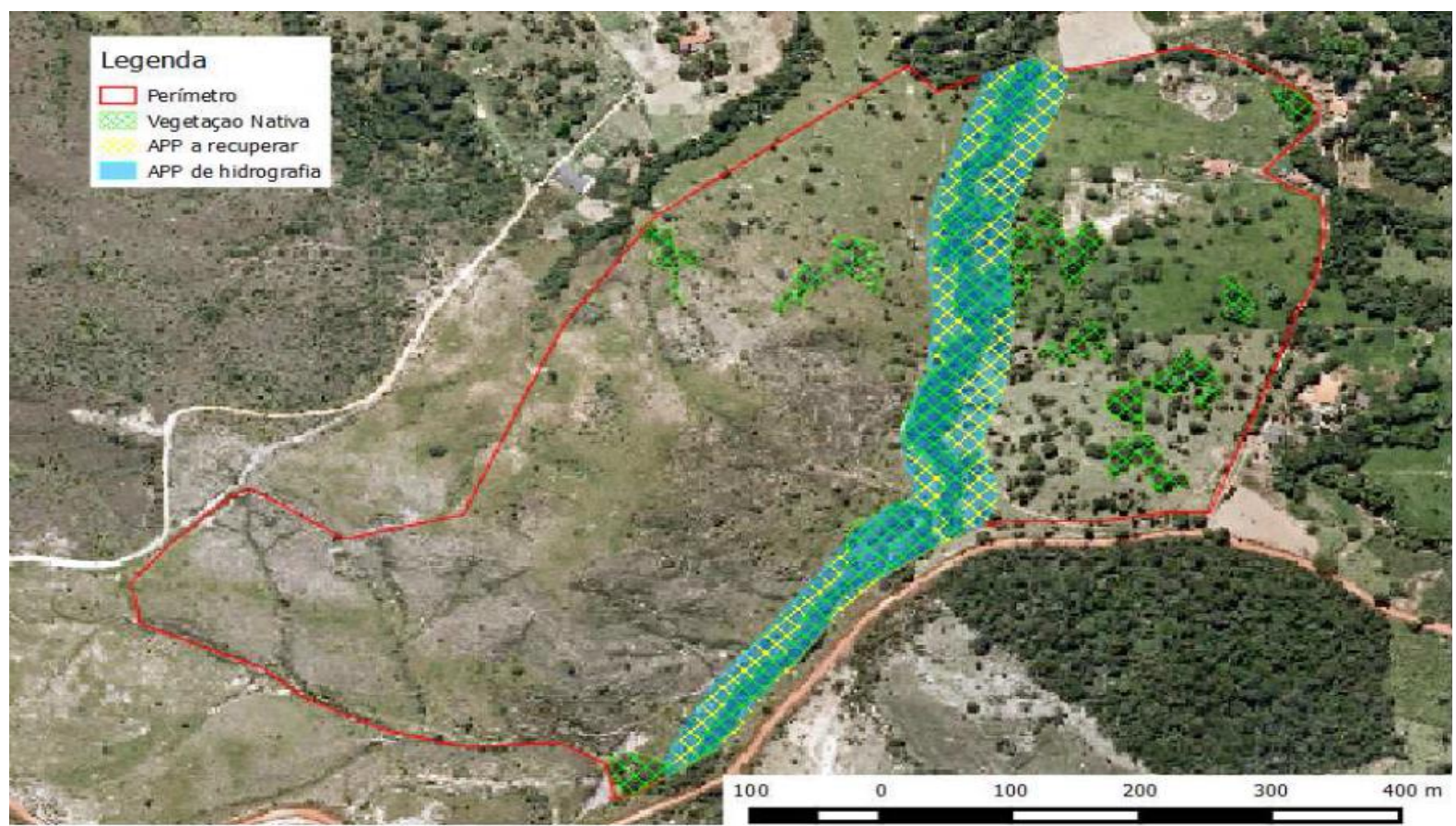

Fonte: COOPERAÇÃO TÉCNICA IBRAM - UNB

Destaca-se na Figura 14 a insuficiência de vegetação nativa (sombreada de verde) na área de preservação permanente e que atenda a proporção necessária a RL. De acordo com os dados, a propriedade do produtor $\mathrm{B}_{8}$ tem uma área de APP de hidrografia (sombreada de azul na Figura 14) de 8,18 hectares $(80,52 \%)$ de um total, que de acordo com a legislação ambiental brasileira, deveria de ser de 10,16 hectares (Tabela 5). Quanto a área de RL, encontrou-se que a propriedade tem um déficit de $100 \%$ do total mínimo ou exigido pela legislação para a área (6,60 hectares).

Com relação ao cumprimento da legislação ambiental brasileira (BRASIL, 2012), quando comparados os dois grupos de produtores avaliados no aspecto do cumprimento das áreas de APP de hidrografia, observou-se que para o caso do grupo A, ainda apresenta um déficit em relação às áreas de APP de hidrografia necessárias. Na verdade, se aproxima do cumprimento com a legislação, devendo recuperar 0,08 hectares de mata. Para 6 das 
propriedades do grupo B (6/8) não aplica o referente às áreas de APP, por não ter interferência a hidrografia indicada pela cartografia oficial do DF nestes imóveis. Com relação às outras 2 propriedades, uma $\left(\mathrm{B}_{7}\right)$ não apresenta diferencias entre o percentual exigido de áreas de APP e o porcentual conservado, já com relação a propriedade $B_{8}$ percebe-se que será necessário trabalhar na recuperação de 1,98 hectares de mata (Tabela 5), se o objetivo for observar a legislação pertinente.

O grupo A diverge no que diz respeito ao percentual necessário ou mínimo exigido de áreas RL e do porcentual conservado, mas segundo o artigo 67 do Novo Código Florestal Lei 12.651 de 2012, ficará com a RL existente enquadrando-se neste aspecto da legislação. No grupo B só 1 dos produtores apresenta diferenças expressivas entre o percentual exigido de áreas RL e o porcentual conservado (Tabela 5). Nos casos em que se apresentam déficits das áreas tanto de APP de hidrografia, quanto de RL, existe a indicação de que se deverá implementar a conversão de áreas agrícolas para áreas de floresta nativa, seguindo o estipulado pela Resolução Conama n. ${ }^{\circ} 429$ de 2011.

\section{Fornecedor de orgânicos.}

\section{Grupo A.}

De acordo com os dados obtidos através da aplicação do formulário (Apêndice B), os produtores conformadores do grupo A foram 8 (8 unidades produtivas), todos eles enquadrados como de agricultura familiar, de acordo com o Novo Código Florestal lei № 12.651, de 2012 (abaixo de 4 módulos fiscais). Os produtores encontram-se alocados no DF dentro da ocupação Chapadinha, no Lago Oeste (Bacia Hidrográfica do Rio Maranhão) e fazem parte integrante da Associação dos Trabalhadores Rurais da Agricultura Familiar do Assentamento Chapadinha (Astraf - DF). Todas as unidades (8/8) receberam a certificação de produtores orgânicos pela OCS no ano 2010, o que lhes permite comercializar seus produtos no Brasil como "Orgânicos", apenas, na venda direta ao consumidor, na merenda escolar (através do Programa Nacional de Alimentação Escolar - PNAE) ou na CONAB (Programa de Aquisição de Alimentos - PAA) de acordo com a regulamentação estabelecida pelo decreto $\mathrm{n}^{\circ} 6.323$ de 2007 (MAPA, 2014e). A totalidade das unidades produtivas encontra-se cadastrada no MAPA.

A posse da terra para este grupo de produtores (8/8 produtores) tem um equivalente para cada propriedade produtiva de 10 hectares. Dentre as principais atividades desenvolvidas 
pelos produtores encontram-se a produção orgânica de hortaliças, galinhas e ovos. Mas evidenciou-se em alguns casos (6/8) a complementação de sua produção orgânica com mandioca, feijão, milho, frutas e plantas medicinais. Também se encontrou que alguns dos produtores (3/8) têm implantado culturas orgânicas mais exigentes e demandadas no mercado orgânico, como a de morango orgânico.

O grupo A de produtores rurais orgânicos, através da Astraf - DF mantem presença no mercado orgânico do DF há aproximadamente 3 anos, nos canais de comercialização: i) feiras de produtores (venda direta ao consumidor final); e ii) mercados institucionais (venda para agentes intermediários), especificamente nas compras Publicas Sustentáveis por meio do Programa de Aquisição de Alimentos (PAA). Além das atividades de produção de orgânicos, o os produtores do grupo destacaram-se por ter foco na inovação, desenvolvendo produtos com processamento mínimo, a partir de atividade como a seleção, higienização, corte, e embalagem de alguns de seus produtos.

“... tentamos oferecer os produtos lavados, eles ficam mais lindos para o cliente lá na feira. Na associação, nós embalamos, por que é mais fácil para o transporte no caminhão e muito mais cômodo para o cliente, eles reconhecem isso. ” Produtor $\mathrm{A}_{1}$.

Atualmente as necessidades e desejos dos consumidores são mais exigentes, devido entre outras razões, à alta frequência de circulação da informação (VILCKAS; NANTES, 2007). O segmento do mercado de orgânicos não está alheio a esta realidade, por este motivo que o grupo A de produtores aposta por um produto de qualidade, a qual pode ser obtida através da mistura de vários aspectos como o oferecimento de produtos orgânicos obtidos em harmonia com a conservação do bioma local, a pontualidade, inovação e o compartilhamento e troca de experiências e conhecimentos. Estes aspectos podem chegar a ser altamente valorizados pelos clientes, evidenciando possíveis vantagens competitivas.

\section{Grupo B.}

No caso dos produtores conformadores do grupo B (8 unidades produtivas), segundo as informações obtidas através da aplicação do formulário de perguntas (Apêndice B), todos eles enquadram-se na designação de agricultura familiar de acordo com o Novo Código Florestal lei $\mathrm{N}^{\mathrm{o}}$ 12.651, de 2012; com exceção de 1 que declarou ter um área maior que 20 
hectares (produtor $\mathrm{B}_{8}$ ). Os produtores, à semelhança do que ocorre com o grupo $\mathrm{A}$, encontram-se alocados no DF.

Do total de produtores do grupo B (8), 4 estão na área de abrangência da Bacia Hidrográfica do Rio São Bartolomeu dos quais $3\left(\mathrm{~B}_{4} ; \mathrm{B}_{5} ; \mathrm{B}_{6}\right.$.) fazem parte do Assentamento Pequeno William fundado no ano 2010 (EMATER, 2013), na região rural de Planaltina. Os outros 4 produtores, $\left(\mathrm{B}_{1} ; \mathrm{B}_{2} ; \mathrm{B}_{3} ; \mathrm{B}_{8}\right)$ situam-se na área de abrangência da Bacia Hidrográfica do Rio Maranhão na região rural de Brazlândia.

Até o mês de julho de 2014, quando ocorreram as últimas entrevistas, nenhuma das unidades produtivas (8/8) recebeu a certificação de produtores orgânicos por nenhum mecanismo de certificação, mas salienta-se que todas elas estão no processo da certificação pela OCS, que lhes permitirá, a futuro, comercializar seus produtos como "Orgânicos" de acordo com as indicações estabelecidas pelo decreto $\mathrm{n}^{\circ} 6.323$ de 2007 (MAPA, 2014e).

Quanto a posse da terra para este grupo de produtores, encontraram-se dados mais variáveis que no grupo A, tem-se produtores com uma área produtiva de 10 hectares (3/8), outro grupo com uma média de 5,4 hectares (3/8); e os outros com 15 e 32 hectares $\left(\mathrm{B}_{7}\right.$ e $\mathrm{B}_{8}$ respectivamente). As principais atividades desenvolvidas pelos produtores deste grupo são focadas na produção orgânica de hortaliças, galinhas e ovos.

Quanto à comercialização dos produtos obtidos pelos agricultores do grupo B, evidenciou-se que não tem presença no mercado orgânico do DF, mas sim como produtores convencionais nos canais de comercialização: i) feiras de produtores (venda direta ao consumidor final); e ii) mercados institucionais (venda para agentes intermediários), especificamente nas compras Públicas Sustentáveis por meio do Programa de Aquisição de Alimentos (PAA). Esta situação tem como consequência o não aproveitamento por parte destes produtores de um adicional de $30 \%$ no preço pago pelo produto orgânico, que é promovido pelos programas de segurança alimentar como o PAA (MACENA, 2011), e que hoje é uma realidade no mercado de orgânicos em geral.

“... a gente tem colegas lá na feira que vede orgânicos com a declaração (Declaração do cadastro do produtor vinculado à OCS) e tem como impor um preço maior ao nosso, se nos tivéssemos aquela declaração teríamos uma vantagem muito grande, além do preço razoável e compensatório." Produtor $\mathrm{B}_{5}$. 
“... o PAA cobra a certificação orgânica para a fixação dos preços, por isso eles pagam como produto convencional, mas com certeza eles acrescentarão o preço quando eu obtiver a certificação.” Produtor $\mathrm{B}_{4}$.

Deve-se destacar que os produtores deste grupo, além de estarem se aproximando cada vez mais à certificação orgânica, estão iniciando com atividades de seleção dos produtos em relação a atributos como o tamanho, coloração e danos mecânicos. Estão ainda, lavando e cortando os produtos. Estas atividades poderiam ser relacionadas com as formas de agregação de valor presentes na agricultura, apresentadas por Vilckas e Nantes (2007).

Em geral, ambos os grupos apresentaram indícios de vantagens competitivas, evidenciando a adoção de diferentes estratégias. No Quadro 19 são apresentados os elementos de criação de valor comprovados a partir da descrição da unidade de análise fornecedores de orgânicos.

Quadro 19 - Elementos de criação de valor presentes na relação comercial fornecedor cliente

\begin{tabular}{c|c|c}
\hline $\begin{array}{c}\text { ELEMENTOS DE } \\
\text { CRIAÇÃO DE VALOR } \\
\text { ANALISADO }\end{array}$ & GRUPO A & GRUPO B \\
\hline Fonte Interna de Valor & $\begin{array}{c}\text { Certificação orgânica } \\
\text { Nível 3 de transição } \\
\text { agroecológica } \\
\text { Cuidado com o médio } \\
\text { ambiente e os recursos naturais }\end{array}$ & $\begin{array}{c}\text { Processo de certificação } \\
\text { orgânica }\end{array}$ \\
$\begin{array}{c}\text { Nível 2 de transição } \\
\text { agroecológica } \\
\text { Cuidado com o médio } \\
\text { ambiente e os recursos naturais } \\
\text { Estratégias/Propostas de Valimentar }\end{array}$ & Soluçãança alimentar \\
\hline Foco da Criação de Valor & Inovação & $\begin{array}{c}\text { Srocessamento mínimo } \\
\text { Processamento mínimo }\end{array}$ \\
\hline
\end{tabular}

Fonte: Desenvolvido pelo autor. 
Observou-se que ambos os grupos possuem fontes de valor interna definidas e valorizadas no mercado, assim o grupo A mantem a maior capacidade de comercialização de orgânicos, conseguido implementar a certificação orgânica (Quadro 19). Este fato que pode ser considerado como muito importante quando se considera que a demanda no mercado de alimentos orgânicos está direcionada para aqueles que contam com o respaldo e a certificação, ou seja, de que o sistema de produção utilizado para a sua produção é verdadeiramente orgânico. Neste sentido Elzakker e Eyhorn (2010) reconhecem que a demanda de mercado por produtos em processo de transição orgânica é limitada, pelo que a maioria dos clientes prefere produtos orgânicos antes que produtos em conversão. Embora que o grupo B, tem tido um reconhecimento através do tempo, de seu trabalho no processo de transição de produtor convencional a produtor orgânico, o que tem gerado um nível de fidelidade que pode perdurar quando eles consigam se certificar.

No caso do cuidado com o meio ambiente e segurança alimentar, são elementos visualizados como fontes de valor interna apresentada por ambos os grupos (Quadro 19), pautadas na qualidade dos alimentos que estão sendo obtidos através dos sistemas de produção livres de insumos químicos agrícolas em associação com a conservação e preservação da biodiversidade e dos recursos naturais próprios das regiões que os abrangem. Esta fonte de valor refere-se ao investimento de tempo nas capacitações das diferentes entidades governamentais (EMATER e SEBRAE) relacionadas à produção sustentável e na aplicação deste conhecimento para se o obter produtos de qualidade ao mesmo tempo em que protegem e preservam o agroecossistema.

No caso da formação de associações, deve-se ressaltar que é uma fonte de valor interna apresentada só no grupo A de produtores rurais. Argumenta-se uma série de motivos que os leva à procura de um trabalho em equipe, como por exemplo: um maior poder de comercialização, maior volume de fornecimento, melhora dos sistemas de produção, acessibilidade à certificação participativa via controle social (OCS e OPAC), maior participação nas atividades dirigidas às capacitações técnicas, redução nos custos de transporte até os mercados, e a realização de processamento mínimo dos produtos. Este último é um sinal de industrialização dos produtos. O associativismo cria todo um marco de uma articulação de estratégias coletivas que criem valor.

Dentre as estratégias ou propostas de valor, a inovação e as soluções customizados estão presentes no grupo A (Quadro 19), o que contribuí com a liderança no mercado de orgânicos, comprovando-se um comprometimento dos produtores associados (8/8) na busca de novidades que possam oferecer soluções às necessidades dos seus clientes. Quando 
referido aos serviços customizados, está-se tratando com nichos de mercado (FERNANDES, 2013); que para o caso do grupo A refere-se à clara proximidade com seus clientes, principalmente nas feiras, com o objetivo de conhecer e compreender quais são as necessidades latentes no mercado e trabalhar no oferecimento das possíveis soluções.

“... Nos temos desenvolvido, aqui no o grupo de associados, uma bandejinha com uma mistura de produtos para saladas, ela já está pronta para consumir, isso é algo que o cliente gosta muito." Produtor $\mathrm{A}_{1}$.

“... sempre tentamos obter produtos nativos, que são novos para muitos clientes, nos conhecemos desde há muito tempo e podem ser diferentes para os nossos clientes, eles ficam com alimentos mais variados...” Produtor $\mathrm{A}_{2}$.

Esta forma de criação de valor é evidenciada no trabalho feito por Fernandes (2013) quem observou que a criação de valor de uma das empresas focais estudadas, foi "empurrada" referindo-se a que aquela empresa desenvolvia inovações que logo seriam ofertadas aos clientes. O processamento mínimo é uma das estratégias presentes nos dois grupos de produtores (Quadro 19), focalizado em diferentes etapas: colheita; seleção manual e classificação; lavagem do produto; mistura (opcional); embalagem; transporte; e distribuição. Com isso os produtores estão oferecendo aos seus clientes maior facilidade na preparação e consumo dos produtos, tendo ganhado fidelidade dos clientes.

“... os clientes da feira sabem que nós temos produtos lavados e escolhidos, por isso todos os produtos nossos são de qualidade, os clientes sempre nos procuram.” Produtor $\mathrm{A}_{2}$. “... os clientes da feira preferem comprar os produtos lavados e cortados, é mais pratico para eles." Produtor $\mathrm{B}_{3}$.

Tem-se que outro elemento de criação de valor comum para os dois grupos é o foco da criação de valor para o cliente (Quadro 19); isto é, os produtores de ambos os grupos priorizam as necessidades dos seus clientes e tentam oferecer de forma rápida e eficiente as soluções, assim os clientes valorizam estas atitudes e os produtores percebem maior disposição a comprar e pagar a mais o valor de seus produtos. 
Relacionamentos comerciais: percepção do produtor rural

Os dois grupos de produtores rurais estudados demostraram possuir fontes de vantagem competitivas tanto internas como externas por meio de elementos de criação de valor que se encontram presentes nos relacionamentos comerciais com os clientes. Nesta secção o objetivo é apresentar a criação de valor nos relacionamentos comerciais entre os grupos de produtores orgânicos e em transição (grupo A e B) e seus clientes por meio do analise de quatro díades, tal como aparece na Figura 15.

\section{Figura 16 - Díades identificadas entre os grupos de produtores e clientes.}
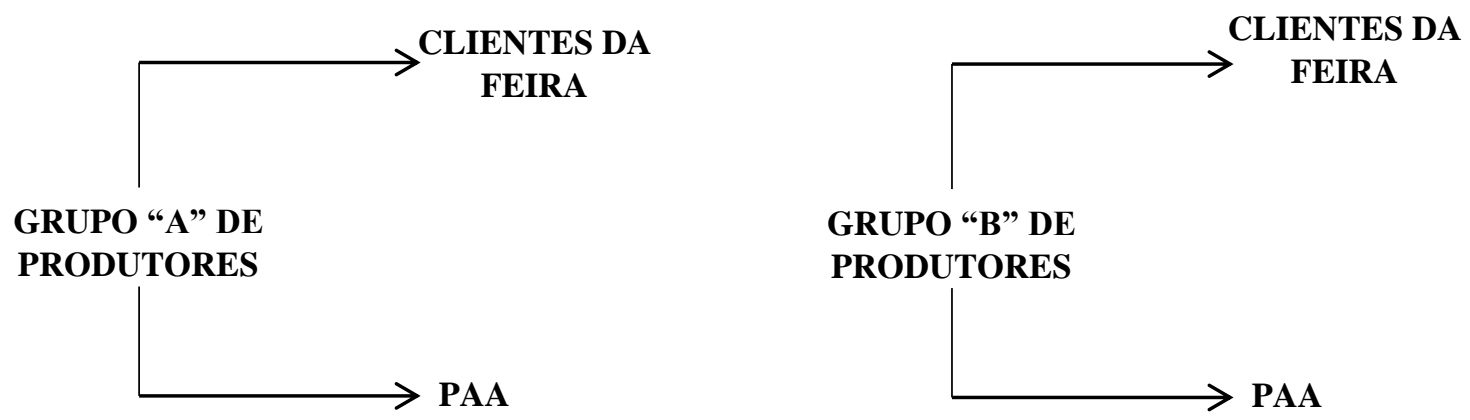

Fonte: Desenvolvido pelo autor.

Evidenciou-se a existência de dois tipos de relacionamentos comerciais, entre o grupo A de produtores rurais com clientes nas feiras e com o PAA; da mesma forma foi identificada a relação comercial entre o grupo $\mathrm{B}$ de produtores rurais e ambos os canais de comercialização (Figura 15).

\section{Grupo A}

Os relacionamentos do grupo A de produtores com seus clientes estão representados por duas díades: grupo $\mathrm{A}$ - feira $\left(\mathrm{A}_{\mathrm{F}}\right)$, grupo $\mathrm{A}$ - PAA ( $\left.\mathrm{A}_{\mathrm{PAA}}\right)$. Foram contemplados 8 relacionamentos para a díade $A_{F}$; e 7 relacionamentos para a díade $A_{\text {PAA }}$ (Quadro 20). No caso da díade $A_{P A A}$ um dos produtores declarou não ter relação comercial com o PAA.

De acordo com os produtores do grupo A (7/8), no longo do tempo o relacionamento comercial com seus clientes da feira - $\mathrm{A}_{\mathrm{F}}$ - tem alcançado características de uma relação colaborativa baseada na confiança mutua, devido à comunicação colaborativa existente entre 
os dois grupos envolvidos, o que tem gerado troca de informação e compartilhamento de conhecimentos com clientes específicos.

Observou-se, da mesma forma, que quando analisados os dados dos clientes da feira pesquisados, a grande maioria (9/10) relatou que existe uma relação de confiança com os fornecedores baseada na benevolência, assim como uma boa comunicação por meio da qual são trocados conhecimentos e informações relacionadas com a saúde, a produção orgânica, os atributos dos alimentos e a segurança alimentar. A complementariedade destas características em um relacionamento comercial gera ganhos e vantagens competitivas (CAO; ZHANG, 2011; CARR; PEARSON, 1999; MAYER et. al., 1995; DYER; SINGH, 1998).

Daí que os relacionamentos comerciais na díade $A_{F}$ caracterizaram-se por ser colaborativos (CAO; ZHANG, 2011; DYER; SINGH, 1998; FERNANDES, 2013; STANK; DITTMANN; AUTRY, 2011). Contudo, encontrou-se que o valor criado através dos relacionamentos comerciais colaborativos foi identificado no aumento da disposição a pagar (DP) dos clientes e na redução do custo de oportunidade do fornecedor (BRANDENBURGER; STUART, 1996). Assim descobriu-se que o valor criado para os produtores do grupo A é refletido na fidelidade dos clientes, no ganho de reputação no mercado, isto tem contribuído para o incremento das vendas. Cria-se um mercado cada vez mais seguro com preços melhores, trazendo para as propriedades, uma maior sustentabilidade produtiva (Quadro 20).

Quanto que o valor criado para os clientes da feira reflete na variedade de produtos, na qualidade dos mesmos e na confiabilidade de que o produto é produzido através da implantação de atividades agrícolas produtivas orgânicas em consonância com o cuidado e preservação do meio ambiente (Quadro 20).

Na díade $\mathrm{A}_{\mathrm{PAA}}$ mantem relacionamentos comerciais mistos, apresentado características tanto dos relacionamentos comerciais colaborativos quanto transacionais. No referente à relação comercial colaborativa, de acordo com os produtores do grupo A (8/8), e com o mercado cliente PAA, o relacionamento comercial caracteriza-se pela existência de confiança nas capacidades e recursos de ambas as partes, além da confiança em que nenhuma das partes pode ser percebida como oportunista.

Foram mencionadas outras características importantes no relacionamento das partes envolvidas (7/8 produtores e PAA), referindo-se à criação e troca de conhecimentos de forma conjunta por meio de uma comunicação colaborativa (CAO; ZHANG, 2011; CARR; PEARSON, 1999; DYER; SINGH, 1998; MAYER; DAVIS; SCHOORMAN, 1995). À semelhança que na díade $A_{F}$, a combinação destas características indicam um relacionamento 
comercial colaborativo presente na díade APAA (CAO; ZHANG, 2011; DYER; SINGH, 1998; FERNANDES, 2013; STANK; DITTMANN; AUTRY, 2011).

A questão referente aos relacionamentos de caráter transacional, a maioria dos produtores (8/8) narraram da existência de contratos com salvaguardas formais, salientando que a relação comercial é mais focada no controle e nos custos (DYER; CHO; CHU, 1998; FERNANDES, 2013), estes resultados estão apresentados no Quadro 20. Neste sentido, o PAA reconhece a existência de um termo de compromisso executado pela Secretaria de Estado de Desenvolvimento Social e Transferência de Renda (SEDEST), o qual contém o tipo de produto e as quantidades que vão a ser fornecidas pelos produtores. Neste termo de compromisso, estão estipulados os preços que serão pagos pelos produtos, os quais são o resultado da média dos preços no mercado atacadista local nos 12 últimos meses, esse preço é mantido pelo tempo que dura o termo.

O fato da utilização do termo de compromisso confere-lhe ao relacionamento comercial presente na díade $\mathrm{A}_{\mathrm{PAA}} \mathrm{o}$ caráter transacional, sendo que o termo poderia ser enquadrado como um mecanismo de governança transacional (POPPO; ZENGER, 2002).

Quadro 20 - Criação de valor no relacionamento grupo de produtores - clientes.

\begin{tabular}{|c|c|c|c|c|c|}
\hline $\begin{array}{l}\text { Categoria do } \\
\text { relacionamento } \\
\text { comercial }\end{array}$ & $\begin{array}{c}\text { Relacionamento } \\
\text { comercial }\end{array}$ & $\begin{array}{c}\mathrm{N}^{\circ} \text { de } \\
\text { relacionamentos } \\
\text { comerciais }\end{array}$ & Valor criado para o cliente & Valor criado para o produtor & $\begin{array}{l}\text { Indicador do } \\
\text { valor criado }\end{array}$ \\
\hline Colaborativo & $A_{F}$ & 8 & $\begin{array}{l}\text { Variedade de produtos; Qualidade; } \\
\text { Confiabilidade, Inovação. }\end{array}$ & $\begin{array}{l}\text { Exclusividade; Incremento das } \\
\text { vendas; sustentabilidade; } \\
\text { Reputação; segurança do } \\
\text { mercado. }\end{array}$ & $\mathrm{DP}+\mathrm{CO}$ \\
\hline Mistos & $\mathrm{A}_{\mathrm{PAA}}$ & 7 & $\begin{array}{l}\text { Cumprimento com o objetivo de } \\
\text { promover o desenvolvimento } \\
\text { nacional sustentável. }\end{array}$ & $\begin{array}{l}\text { Preço fixo dos produtos durante } \\
\text { tudo o ano; Segurança do } \\
\text { mercado; sustentabilidade. }\end{array}$ & $\mathrm{DP}$ \\
\hline Colaborativo & $\mathrm{B}_{\mathrm{F}}$ & 8 & Variedade de produtos; Qualidade. & $\begin{array}{c}\text { Incremento das vendas; } \\
\text { Reputação; Segurança do } \\
\text { mercado. }\end{array}$ & $\mathrm{CO}$ \\
\hline Mistos & $\mathrm{B}_{\mathrm{PAA}}$ & 4 & $\begin{array}{l}\text { Cumprimento com o objetivo de } \\
\text { promover o desenvolvimento } \\
\text { nacional sustentável. }\end{array}$ & $\begin{array}{c}\text { Preço fixo dos produtos durante } \\
\text { tudo o ano; Segurança do } \\
\text { mercado. }\end{array}$ & - \\
\hline
\end{tabular}

DP: Disposição a pagar por o produto; CO: Redução do custo de oportunidade; $\mathbf{A}_{\mathbf{F}}$ : relação comercial entre os produtores do grupo A e os clientes da feira; $\mathbf{A}_{\mathbf{P A A}}$ : relação comercial entre os produtores do grupo A e o mercado institucional; $\mathbf{B}_{\mathbf{F}}$ : relação comercial entre os produtores do grupo B e os clientes da feira; $\mathbf{B}_{\mathbf{P A A}}$ : relação comercial entre os produtores do grupo B e o mercado institucional.

Fonte: Desenvolvido pelo autor. 
Embora tenha sido possível evidenciar processos desenvolvidos que influenciaram no custo de oportunidade, o valor criado através dos relacionamentos comerciais mistos existentes entre os produtores do grupo A e o mercado cliente PAA, foi refletido no aumento da disposição a pagar (DP) do cliente (BRANDENBURGER; STUART, 1996). Tem-se que o valor criado para os produtores do grupo $\mathrm{A}$ nesta díade $\left(\mathrm{D}_{\mathrm{PAA}}\right)$ é refletido na garantia do preço dos produtos durante tudo o ano, na certeza de ter um mercado constante e seguro gerado pela garantia da compra, e na sustentabilidade produtiva (Quadro 20); quanto que o valor criado para o PAA é evidenciado no avanço no objetivo da promoção do desenvolvimento nacional sustentável (Quadro 20).

\section{Grupo B}

Os relacionamentos comerciais do grupo B de produtores com seus clientes estão representados de igual forma que no grupo $\mathrm{A}$, por duas díades: grupo $\mathrm{B}-$ feira $\left(\mathrm{B}_{\mathrm{F}}\right)$, grupo $\mathrm{B}$ - PAA $\left(\mathrm{B}_{\mathrm{PAA}}\right)$. Foram observados 8 relacionamentos para a díade $\mathrm{B}_{\mathrm{F}}$; e só 4 relacionamentos para a díade grupo $\mathrm{B}_{\mathrm{PAA}}$ (Quadro 20), ou seja, só quatro dos produtores do grupo B (4/8) argumentaram ter relações comerciais com o PAA, mas como produtores rurais convencionais.

Assim, de acordo com os dados fornecidos pelos produtores do grupo B, os 8 produtores evidenciaram manter um relacionamento comercial com seus clientes da feira $-B_{F}$ com fracas características colaborativas (Quadro 20), e nenhuma característica transacional. Ou seja, ainda sendo os relacionamentos baseado na comunicação e na troca de informação e compartilhamento de conhecimentos, entre as duas partes envolvidas (grupo de produtores e clientes da feira), características que esboçam um relacionamento comercial colaborativo (CAO; ZHANG, 2011; DYER; SINGH, 1998; FERNANDES, 2013; STANK; DITTMANN; AUTRY, 2011); o relacionamento comercial está se dando num cenário de baixo nível de confiança, no qual persiste a necessidade de documentos comprovatórios da qualidade orgânica dos produtos.

“... eu não posso confiar em que meus clientes estão atuando de forma correta, pois eles sabem que eu estou produzindo de forma natural, orgânica, mas eles não vão a pagar o preço correto, porque eu não tenho meu certificado." Produtor $\mathrm{B}_{4}$. 
“... eu como comprador, conheço o produtor, mas eu não posso acreditar em que o produto é $100 \%$ orgânico, pois eles não tem o certificado." Cliente $\mathrm{C}_{3}$.

O valor criado a traves dos relacionamentos comerciais colaborativos evidenciou-se na redução do custo de oportunidade do fornecedor (BRANDENBURGER; STUART, 1996). Além disso, foi evidenciado que o valor criado para os produtores do grupo B reflete no incremento das vendas, isto está relacionado ao fato de que com o tempo, este grupo de produtores tem ganhado mais clientes que conhecem seus produtos, criando uma reputação como produtores "naturais", que estão no processo de transição para produtores orgânicos, que participam do processo de certificação pela OCS da comunidade. Deve ser mencionado que os produtores do grupo B estão buscando para uma segurança do mercado. $\mathrm{O}$ valor criado para os clientes da feira esta sendo refletido na variedade de produtos de qualidade e no menor preço relativo que os produtos orgânicos certificados. (Quadro 20).

$\mathrm{A}$ díade $\mathrm{B}_{\mathrm{PAA}}$ mantem relacionamentos comerciais mistos com caraterística predominantemente transacional. A caraterística de colaborativa que foi dada ao relacionamento comercial na díade $\mathrm{B}_{\mathrm{PAA}}$, está baseada tanto nas opiniões dadas pelos produtores do grupo B, quanto nas informações obtidas junto ao cliente PAA. Constatou-se que, à semelhança da díade $\mathrm{A}_{\mathrm{PAA}}$, o relacionamento comercial caracteriza-se pela existência de confiança nas capacidades e recursos de ambas as partes (4/4 produtores e opinião do PAA). Além, as duas partes (4/4 produtores e opinião do PAA) concordam na existência de uma comunicação colaborativa por meio da qual tem alcançado intercâmbio de informações (CAO; ZHANG, 2011; DYER; SINGH, 1998; MAYER; DAVIS; SCHOORMAN, 1995), o que tem contribuído no melhor planejamento da produção. Estas características convergem num relacionamento comercial colaborativo presente na díade $\mathrm{B}_{\mathrm{PAA}}$ (CAO; ZHANG, 2011; DYER; SINGH, 1998; FERNANDES, 2013; STANK; DITTMANN; AUTRY, 2011).

As caraterísticas transacionais do relacionamento comercial foram dadas pelos produtores (4/4) que argumentaram de maneira semelhante aos produtores presentes na díade $\mathrm{A}_{\mathrm{PAA}}$, a existência de contratos com salvaguardas focadas no controle da quantidade fornecida e dos custos dos produtos (DYER; CHO; CHU, 1998; FERNANDES, 2013; POPPO; ZENGER, 2002), contratos que, da mesma forma que no caso da díade $A_{\text {PAA, foram }}$ representados pela existência do termo de compromisso executado pela SEDEST. Não foi possível evidenciar processos desenvolvidos que influenciaram no custo de oportunidade (CO), nem no aumento da disposição a pagar (DP) do cliente (BRANDENBURGER; 
STUART, 1996). Finalmente, o valor criado para os produtores do grupo B nesta díade (B PAA $_{\text {P }}$ foi identificado na segurança do mercado e no preço fixo dos produtos, ainda sendo pagos

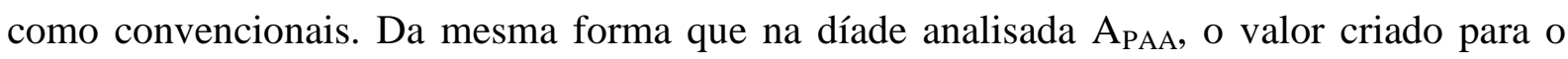
mercado cliente PAA é evidenciado na promoção do desenvolvimento nacional sustentável (Quadro 20).

Processos de criação de valor: percepção do produtor rural.

Em cada uma das díades evidenciadas pelos relacionamentos expostos, o valor criado se manifestou por meio de processos que visam contribuir para os dois lados. O valor criado pela relação comercial vai ser identificado como $V_{C}$, de acordo com Fernandes (2013), o $V_{C}$ é o resultado de um processo interativo entre duas ou mais partes conformadoras de uma relação comercial transacional. É assim como por meio desta unidade de analise tentou-se identificar e entender quais formam os mecanismos de criação de valor adotados nos relacionamentos comerciais entre os produtores e clientes.

Para identificar os processos de criação de valor foram levadas em conta as três etapas propostas por Fernandes (2013) as quais sejam: início, desenvolvimento e benefícios; de acordo com a autora, os resultados advindos desses processos são identificados como o $\mathrm{V}_{\mathrm{C}}$ (benefícios) para os fornecedores (produtores rurais), refletidos na redução do custo de oportunidade (CO); e/ou para os clientes, manifestado no aumento da disposição a pagar (DP) (BRANDENBURGER; STUART, 1996).

O início do processo de criação de valor é impulsionado por eventos ou episódios, relacionados a dois contextos diferentes: inovação ou necessidade (FERNANDES, 2013). De acordo com Fernandes (2013), quando o inicio se dá pelo fornecedor num contexto de inovação, é caracterizado pela oferta de um novo desenvolvimento para o cliente; quando direcionado pelo cliente no mesmo contexto, sua característica relaciona-se pela existência de um desenvolvimento do cliente que precisa das competências do fornecedor para a sua execução. Além disso, a autora argumenta que num contexto de necessidade, o início do processo pode ser impulsionado pelo cliente, devido à sua própria necessidade; ou pela fornecedora que oferece soluções uma vez passa a conhecer as necessidades do cliente (FERNANDES, 2013).

$\mathrm{Na}$ etapa de desenvolvimento a característica principal e norteadora da análise, relaciona-se com a contribuição relativa dos parceiros. Por este motivo que se fez necessária a 
pesquisa do desenvolvimento dos processos de criação de valor, e segundo a Fernandes (2013), pode ser utilizado o Process-tracing proposto por George e Bennett (2005), visando evidenciar e entender, os processos que permitem viabilizar a criação de valor. Como resultado da análise do Porcess- tracing e tendo como base os três mecanismos de criação de valor identificados por Fernandes (2013), conseguiu-se delinear dois mecanismos de criação de valor imersos na etapa de desenvolvimento do processo de criação de valor nos relacionamentos comerciais entre os produtores rurais e os clientes; os mecanismos foram denominados como de: Construindo confiança (práticos para as díades $\mathrm{A}_{\mathrm{F}}$ e $\mathrm{B}_{\mathrm{F}}$ ) e Benefícios mútuos (práticos para as díades $\left.\mathrm{A}_{\mathrm{PAA}} ; \mathrm{B}_{\mathrm{PAA}}\right)$.

\section{Mecanismo: Construindo Confiança.}

O mecanismo caracteriza-se por ter um início marcado pela participação bilateral entre os produtores rurais e os clientes da feira devido à sua proximidade proporcionada pelo alto conteúdo de comunicação (Figura 16). Neste sentido, o inicio se dá nos contextos inovação e necessidade. O início do processo no contexto de necessidade é impulsionado tanto pelo cliente, devido à necessidade de gerar ações que estimulem a melhora da sua saúde e da proteção do meio ambiente, quanto pelos produtores que identificaram estas necessidades e estiveram dispostos a atingi-las, voltando-se para o sistema de produção orgânico. O início foi impulsionado pelo fornecedor num contexto de inovação, caracterizado pela oferta de novos produtos, novas apresentações dos mesmos, apresentação de embalagens que geram maior facilidade para o transporte desde a feira até a casa do cliente.

Quando se menciona a existência de confiança na relação comercial, refere-se à existência de confiança sem ter a necessidade de contratos formais, baseada nas competências dos produtores rurais por parte dos clientes, e na confiança (benevolência) que tem os fornecedores em que obterão benefícios econômicos ao desenvolverem novos produtos como soluções para as necessidades de seus clientes (DYER; SINGH, 1998; MAYER; DAVIS; SCHOORMAN, 1995) (Figura 16). Encontrou-se que a confiança baseada em benevolência é predominante no mecanismo, ocorrendo o processo de criação de valor principalmente pelas competências internas dos produtores, relacionadas com a certeza dos processos produtivos, qualidade e cuidado com o meio ambiente. 
Figura 17 - Mecanismo de criação de valor: Construindo Confiança.

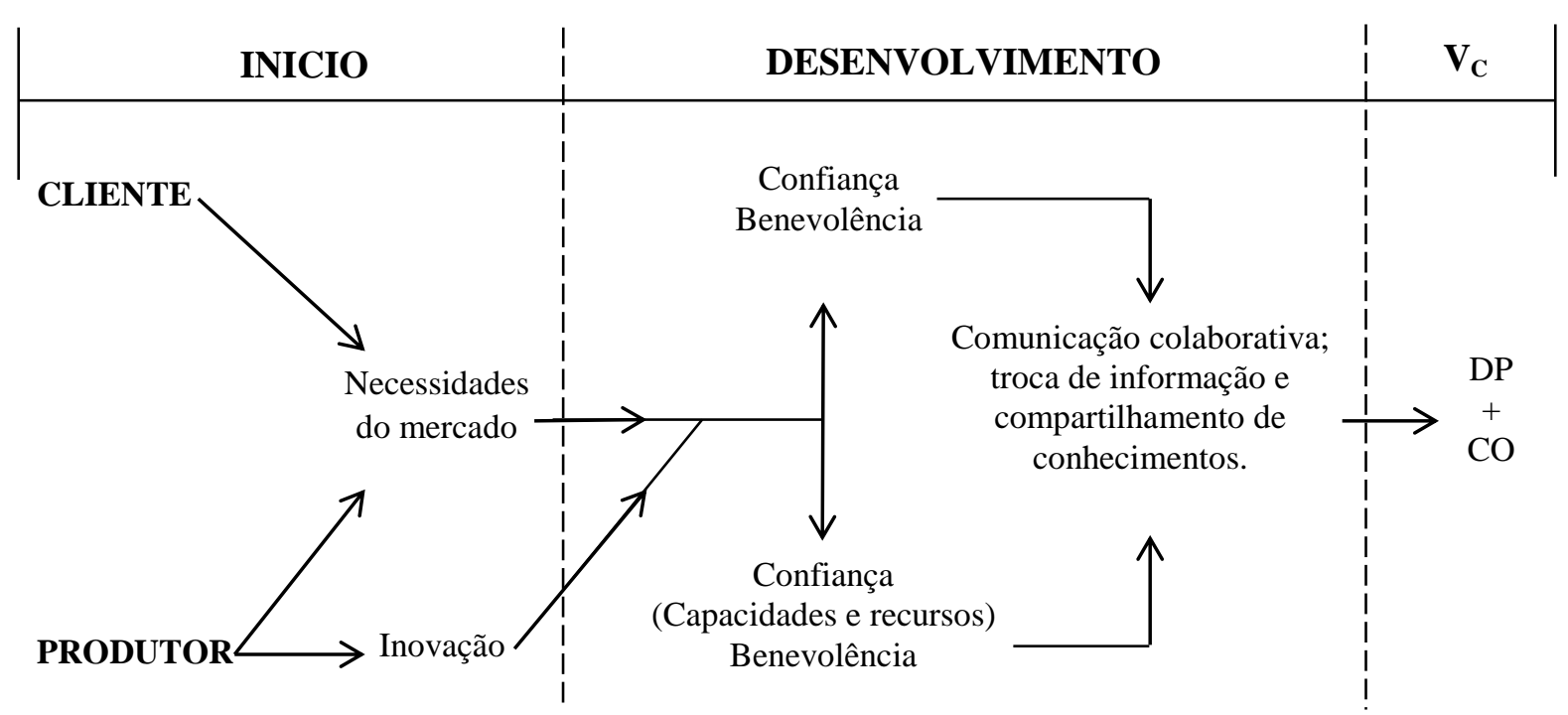

Fonte: Desenvolvido pelo autor.

Uma vez que o produtor faz entrega do produto, o cliente confia em que este cumpre com as qualidades de um produto orgânico, destacando-se que o cliente assume os riscos envolvidos (WILLIAMSON, 1981). Aqueles riscos são assumidos na díade $\mathrm{B}_{\mathrm{F}}$ por ambas as partes, no caso dos clientes, pois se poderiam gerar situações oportunistas (HOBBS, 1996; WILLIAMSOM, 1991) por parte dos produtores no momento do fornecimento de informação falsa respeito ao sistema de produção; já no caso do produtor, ele confia em que uma vez obtida a declaração de produtor orgânico o cliente pagará o preço justo pelos produtos. Aqueles riscos são maiores na relação entre os produtores do grupo B e os clientes da feira que na díade $\mathrm{A}_{\mathrm{F}}$. Finalmente é inicializado o processo de comunicação colaborativa, troca de informação e compartilhamento de conhecimentos (Figura 16); cuja complementariedade vislumbra uma forte fase de envolvimento (DYER; SINGH, 1998).

Uma vez finalizada a etapa de desenvolvimento, se tem os benefícios como resultados do processo ou $\mathrm{V}_{\mathrm{C}}$ (Figura 16), em outras palavras, se obtém a materialização do processo que é refletido no aumento da disposição a pagar e na redução do custo de oportunidade (BRANDENBURGER; STUART, 1996). 
Mecanismo: Benefícios mútuos.

$\mathrm{O}$ relacionamento entre o PAA e os fornecedores caracteriza-se por ter como iniciadores os produtores e os compradores (Figura 17), mantendo um envolvimento de ambas as partes (produtores e mercado cliente PAA), evidenciando-se uma complementariedade de recursos (DYER; SINGH, 1998). No caso dos produtores, possuíam o Know - how (MIOR, 2007), e no caso do PAA oferece um mercado seguro, além de oferecer o serviço de extensão técnica, em parceria com o EMATER.

No mecanismo construindo confiança, encontrou-se que se apresenta uma governança interna que busca eficácia e troca de informação, relações pertencentes à RV (DYER; SINGH, 1998). O início da relação foi impulsionado tanto pelo cliente, devido à necessidade de produtos de qualidade provenientes da agricultura familiar com o objeto de promover o desenvolvimento nacional sustentável; quanto pelos produtores que identificaram esta necessidade, além de almejar um mercado seguro para seus produtos (Figura 17). O início pode ser caracterizado como de participação bilateral.

A confiança que foi identificada esteve baseada em benevolência, que de acordo com Fernandes (2013) é uma dimensão primordial numa relação comercial que envolve investimentos de ambas as partes. Para os casos estudados, encontram-se envolvidos recursos tanto do governo, através das compras públicas (PAA), e nos serviço de extensão técnica, quanto dos produtores, que desenvolvem os sistemas de produção orgânica ou que se encontram em processo de transição (grupo B). Isto porque envolve investimentos de tempo e dinheiro por parte dos produtores.

Nesta pesquisa foi identificada uma estrutura de governança interna que utiliza procedimentos os quais contribuem para reduzir os riscos nas transações por meio do termo de compromisso (FERNANDES, 2013; RINDFLEISCH; HEIDE, 1997) pelo qual são comprometidos os produtores a fornecer uma quantidade que qualidade determinada num tempo estipulado. Em contrapartida o cliente compromete-se a garantir o mercado e os preços estipulados de acordo com a média no mercado atacadista local. Porém, foram reduzidos os níveis de incerteza e os comportamentos oportunistas de qualquer uma das partes (HOBBS, 1996; WILLIAMSOM, 1991). Encontrou-se que a confiança baseada nos recursos e nas capacidades de ambas as partes, é predominante no relacionamento. 
Figura 18 - Mecanismo de criação de valor: Benefícios mútuos.

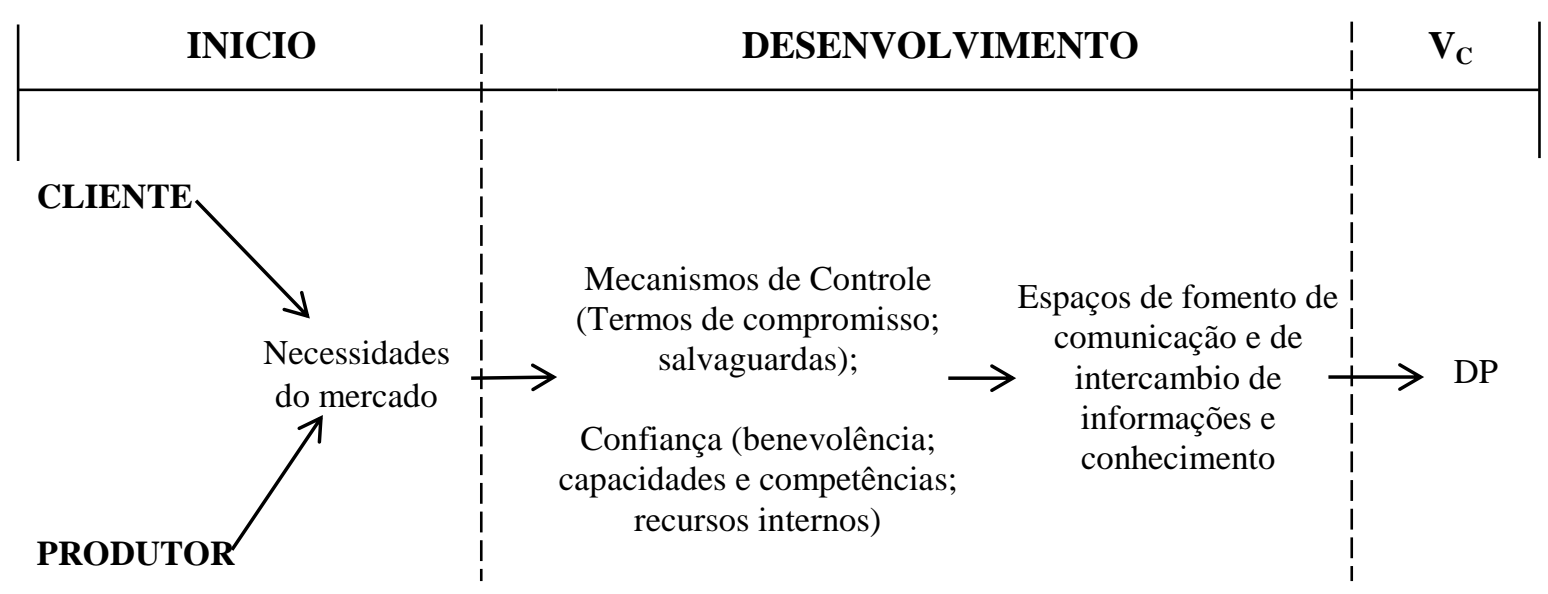

Fonte: Desenvolvido pelo autor.

Quando feita a entrega do produto por parte do produtor, o cliente confia em que este cumpre com as qualidades de um produto orgânico, assumindo os riscos envolvidos (WILLIAMSON, 1981), más além do termo de compromisso assumido pelas partes, é exigido ao produtor a declaração de produtor orgânico, se este não apresentar, os produtos serão pagos de acordo com a tabela de preços para produtos convencionais. Os riscos envolvidos neste tipo de negociação são reduzidos por meio do uso destas salvaguardas formais (HOBBS, 1996; RINDFLEISCH; HEIDE, 1997; WILLIAMSOM, 1991). Finalmente se dá o inicio do envolvimento caracterizado como um espaço em construção onde é fomentada a comunicação participativa, assim como o intercâmbio de informações e de conhecimentos, (Figura 17) (DYER; SINGH, 1998).

Da mesma forma que no processo de criação de valor para as díades $A_{F}$ e $B_{F}$, uma vez finalizada a etapa de desenvolvimento, foram identificados os benefícios como resultados do processo; que para o caso da díade $\mathrm{A}_{\mathrm{PAA}}$ foi refletido no aumento da disposição a pagar, explicação de valor econômico criado proposto por Brandenburger e Stuart (1996). Não foram obtidas evidencias que pudessem indicar uma redução do custo de oportunidade e/ou na disposição de se pagar a mais, para o caso da díade B BAA (Figura 17).

\subsection{Percepção dos clientes quanto à criação de valor.}

Nesta seção, são apresentados os resultados da analise da percepção dos clientes de produtos orgânicos quanto à criação de valor. Busca-se identificar os mecanismos de criação 
de valor nos relacionamentos comerciais entre os clientes e os produtores fornecedores. Tanto o mercado institucional, que faz parte dos agentes intermediários, quanto as os clientes das feiras de orgânicos, foram analisados na seção anterior.

\section{Mercado cliente de produtos orgânicos.}

\section{Supermercados.}

Os supermercados foram indicados como $\mathrm{S}_{1}$ até $\mathrm{S}_{4}$. Os supermercados avaliados são empresas que atuam no setor de orgânicos dentro do DF, entre elas encontram-se empresas de médio e grande porte. Dois dos supermercados (2/4) fazem parte de um grupo de grande varejo, líderes mundiais no varejo de alimentos, com mais de 1.992 pontos de venda. O grupo mantem lojas físicas e operações de comércio eletrônico, divididos em segmentos: Varejo Alimentar, Atacado de Autosserviço, Eletro e Móveis, Comércio Eletrônico e Galerias. Outro dos supermercados faz parte de uma cadeia de distribuição multinacional de origem francesa. E o ultimo supermercado faz parte de uma cadeia de varejo com origem nacional.

Todos os supermercados amostras cobrem o setor de comercialização de produtos orgânicos, em variadas apresentações. Os supermercados contam com sedes no todo DF, para um total de 32 locais. Este grupo pertencente aos intermediários é o maior dos grupos, com relacionamentos comerciais de longo prazo (acima de 10 anos), contando com fornecedores que atingem as especificações de qualidade e quantidade de produtos orgânicos. Os relacionamentos puderam ser classificados como mistos, apresentando de forma equivalente características relacionais colaborativas e transacionais.

A totalidade da amostra de supermercados (4/4) relatou existir confiança no relacionamento comercial com seus fornecedores; confiança que tem gerado um ambiente de criação e troca de conhecimentos tanto técnicos por parte dos produtores fornecedores (conhecimento em produção, técnicas de manuseio dos produtos e qualidades do produto), quanto mercadológicos por parte dos supermercados (conhecer as demandas e interpretar as demandas do mercado cliente), fazendo uso de uma comunicação constante, que pressupõe que a transferência dessas informações será interpretada de forma conjunta para criar um conhecimento comum ocorrendo um aprendizado através de um relacionamento comercial colaborativo (CAO; ZHANG, 2011; DYER; SINGH, 1998; FERNANDES, 2013; STANK; DITTMANN; AUTRY, 2011). 
“... Nosso fornecedor leva à gente duas vesses por ano até a fazenda, lá ele fala como começou, como é que produz como é o manuseio dos produtos, e fala sobre as qualidades e bondades dos produtos orgânicos à saúde. De nossa parte, tentamos sempre mantê-lo informado na parte do mercado, passamos informação relacionada com as demandas dos nossos clientes e como ele (o fornecedor) poderia atingir aquelas demandas...". $\mathrm{S}_{2}$.

O caráter transacional dado à relação comercial entre o supermercado e os produtores fornecedores, deve-se a existência de contratos com salvaguardas formais (POPPO; ZENGER, 2002). As salvaguardas estão focadas principalmente à exigência do selo de certificação orgânica, ao controle da qualidade física dos produtos, do volume fornecido, do preço e da frequência de abastecimento.

Varejo de pequeno porte.

As unidades conformadoras do grupo varejo de pequeno porte foram indicadas como $\mathrm{V}_{1}$ até $\mathrm{V}_{3}$. Este grupo de intermediários caracteriza-se por ter um tempo no mercado de orgânicos de mais de 20 anos, oferecendo produtos de qualidade aos consumidores finais. Encontram-se alocados no DF, mas são poucos, tendo em conta o grande porte e a capacidade de negociação dos supermercados. Os relacionamentos comerciais que foram observados entre o grupo de varejo de pequeno porte e os produtores fornecedores, apresentam grande carga relacional. Evidenciou-se uma proximidade gerada pelo alto comprometimento das duas partes em relação aos benefícios mútuos, o que tem originado uma forte relação comercial baseada na comunicação constante. Embora que a relação comercial não seja formal, tem-se desenvolvido como consequência da existência do alto nível de comunicação, um ambiente de troca de conhecimentos e informações onde ambas as partes buscam acordos que possam ser mutuamente benéficos.

Neste sentido encontraram-se altos níveis de confiança baseada nas capacidades e competências de ambas as partes. Por sua parte, o varejo de pequeno porte oferece um mercado seguro, sem importar o volume fornecido, sempre que os produtos cumpram com a qualidade mínima estipulada pelo comprador.

Salienta-se que existe, também, um alto nível de confiança baseada na benevolência por parte do grupo de varejo de pequeno porte, pois evidenciaram ter certeza de que o produtor fornecedor não terá ações oportunistas, referindo-se com isto que existe a seguridade 
de que os produtores sempre forneceram produtos obtidos sob sistemas de produção orgânica. Pelo exposto, o relacionamento comercial entre o grupo do varejo de pequeno porte e os produtores fornecedores comprometem características predominantemente colaborativas (CAO; ZHANG, 2011; DYER; SINGH, 1998; FERNANDES, 2013; STANK; DITTMANN; AUTRY, 2011).

\section{Restaurantes.}

As unidades conformadoras do grupo restaurante foram indicadas como $R_{1}$ até $R_{5}$. Este grupo de intermediários está composto por restaurantes que atuam no setor de alimentos orgânicos processados prontos para o consumo. Ainda sendo um dos grupos pertencente aos intermediários menores, 4 deles (4/5) mantem relacionamentos comerciais de longo prazo (acima de 15 anos), contando com só um produtor fornecedor. Esta característica tem originado uma relação comercial próxima, qualificada por 4 dos 5 restaurantes, como uma relação de parceria.

A comunicação, à semelhança das díades anteriores, é a base do relacionamento comercial entre os restaurantes e os produtores fornecedores. Partindo desta afirmação, encontrou-se que existe um alto fluxo de informação bilateral referente ao conhecimento técnico de produção e manuseio dos produtos orgânicos com processamento mínimo, e em relação a informação e conhecimento mercadológico.

A relação comercial tem um forte componente de confiança entre as partes, o que faz com que se reduza a incerteza de ações oportunistas no momento da transação. Assim, foi possível identificar que o relacionamento comercial entre a maioria dos restaurantes (4/5) e os produtores fornecedores, enquadra-se como relacionamento comercial colaborativo (CAO; ZANG, 2011; DYER; SINGH, 1998; FERNANDES, 2013), com exceção de um (1/5) que apresentou relacionamentos comerciais com características predominantemente transacionais (DYER; CHO; CHU, 1998; RINDFLEISCH; HEIDE, 1997; POPPO; ZENGER, 2002), baseados em salvaguardas formais com foco no controle de custos e de volume e frequência de fornecimento.

Em geral, os três grupos evidenciaram elementos de criação de valor nas relações comerciais com os produtores fornecedores, por meio da adoção de diferentes estratégias (Quadro 21). 


\section{Quadro 21 - Elementos de criação de valor presentes na relação comercial mercado cliente - produtor fornecedor de orgânicos.}

\begin{tabular}{|c|c|c|c|}
\hline $\begin{array}{c}\text { ELEMENTOS DE } \\
\text { CRIAÇÃO DE } \\
\text { VALOR } \\
\text { ANALISADO } \\
\end{array}$ & SUPERMERCADOS & $\begin{array}{c}\text { VAREJO DE } \\
\text { PEQUENO PORTE }\end{array}$ & RESTAURANTES \\
\hline \multirow{3}{*}{$\begin{array}{c}\text { Estratégias/Propostas } \\
\text { de Valor }\end{array}$} & $\begin{array}{c}\text { Segurança do } \\
\text { mercado, só com } \\
\text { apresentação do selo. }\end{array}$ & $\begin{array}{l}\text { Segurança do mercado } \\
\text { sem exigir selo de } \\
\text { certificação orgânica }\end{array}$ & $\begin{array}{l}\text { Segurança do mercado } \\
\text { sem exigir selo de } \\
\text { certificação orgânica }\end{array}$ \\
\hline & $\begin{array}{c}\text { Garantia de volume de } \\
\text { compra }\end{array}$ & & \\
\hline & Negociação de preços & $\begin{array}{c}\text { Mecanismos informais } \\
\text { de transação }\end{array}$ & $\begin{array}{c}\text { Mecanismos informais } \\
\text { de transação }\end{array}$ \\
\hline $\begin{array}{c}\text { Estratégias/Propostas } \\
\text { de Valor }\end{array}$ & $\begin{array}{l}\text { Mecanismos formais } \\
\text { de transação } \\
\text { Compartilhamento de } \\
\text { conhecimento } \\
\text { mercadológico }\end{array}$ & $\begin{array}{l}\text { Compartilhamento de } \\
\text { conhecimento, técnico } \\
\text { produtivo e } \\
\text { mercadológico }\end{array}$ & $\begin{array}{c}\text { Compartilhamento de } \\
\text { conhecimento, técnico } \\
\text { produtivo e } \\
\text { mercadológico }\end{array}$ \\
\hline $\begin{array}{c}\text { Foco da Criação de } \\
\text { Valor }\end{array}$ & Produtor fornecedor & Produtor fornecedor & Produtor fornecedor \\
\hline
\end{tabular}

Fonte: Desenvolvido pelo autor.

De acordo com o exposto, os três grupos aplicam estratégias de valor bem definidas e que são valorizadas pelos produtores fornecedores de orgânicos. Encontrou-se que o grupo dos supermercados possui maior capacidade de comercialização de produtos orgânicos, sendo que ao exigir o selo orgânico a seus fornecedores (Quadro 21) está adentrando-se num mercado de maiores volumes de comercialização com preços superiores, questão que fora reconhecida por Elzakker e Eyhorn (2010). Mesmo assim, foi possível identificar uma garantia de volumes de compra por parte dos supermercados, gerando maior confiança entre os produtores fornecedores que à sua vez estão comprometidos em manter ou aumentar o volume de fornecimento.

Ainda que os outros dois grupos não exijam o selo de certificação, existe confiança em que os produtores fornecedores implementaram adequadamente as práticas próprias de um sistema de produção orgânico. Esta confiança tem se desenvolvido no decorrer do tempo da relação comercial, um fato que pode ser comprovado pelos volumes estáveis de venda, próprios destes canais de comercialização. Mesmo assim, evidenciou-se que não existe uma garantia de volume de fornecimento, mas também não é uma exigência nos processos de transação destes dois grupos de mercados clientes (varejo de pequeno porte e restaurantes). 
Tanto a negociação dos preços, quanto o compartilhamento de conhecimento técnico ou mercadológico, são elementos visualizados como estratégias de agregação de valor nos três grupos (Quadro 21). Fato que pode ser derivado da existência de relações comerciais que fazem uso de uma ativa comunicação, o que tem gerado relações baseadas na confiança mutua.

Evidenciou-se que o elemento de criação de valor focado no produtor fornecedor (Quadro 21) é comum nos três grupos, o que pode ser explicado pelo fato dos clientes intermediários trabalharem de forma integrada com os produtores fornecedores visando a criação de oportunidades de novos mercados. No caso dos supermercados, apresenta-se um trabalho em parceria com os produtores fornecedores, que implicam a participação dos departamentos de desenvolvimento de ambas as partes, em procura de atingir as diferentes demandas do mercado.

“... O pessoal de desenvolvimento do Supermercado passa as demandas dos clientes para nosso fornecedor. Eles também oferecem inovações, hoje nos temos novas apresentações dos produtos com processamento mínimo. O fornecedor passa informação sobre novos produtos, novas técnicas...". $\mathrm{S}_{2}$.

Nos relacionamentos comerciais entre os grupos de varejo de pequeno porte e restaurantes com os produtores fornecedores, evidenciaram-se atividades integradas mais próximas entre as partes, tais como visitas frequentes às unidades produtivas e alto nível de comunicação colaborativa envolvendo troca de informações técnicas e de mercado por meio de reuniões face to face. Assim, as partes buscam desenvolver relacionamentos comerciais mais próximos em função do alto potencial que apresentam as partes no mercado, com expectativas de retorno futuro (MIGUEL, 2012).

“... Nós temos total confiança no produtor, e ele em nos. O fornecedor se tornou amigo da família, a gente não tem um contrato, o contrato é de boca e para a gente funciona muito bem. A gente conhece a propriedade, a família, a forma que ele produz, trocamos informações de determinados produtos que a gente não conhece, como manusear os produtos, todo isso ele ensina. Nos passamos para ele informação de produção que ele não conheça, novas sementes, novos produtos, o que produtos estão demandando hoje os nossos clientes e hoje ele já produz e oferece...". $\mathrm{V}_{2}$. 
Estas atividades conjuntas geram confiança nas duas dimensões (na capacidade técnica e benevolência) apresentando reduções no custo de oportunidade por parte dos produtores fornecedores e um aumento na disposição a pagar pelo mercado cliente (BRANDENBURGER; STUART, 1996).

Relacionamentos comerciais: percepção do mercado cliente

Nesta seção é apresentada a criação de valor nos relacionamentos comerciais entre o os agentes intermediários (representados pelos supermercados, os varejos de pequeno porte e os restaurantes) e os produtores fornecedores de orgânicos por meio do analise de três díades, tal como na Figura 18.

\section{Figura 19 - Díades identificadas entre os agentes intermediários e os produtores fornecedores de orgânicos.}

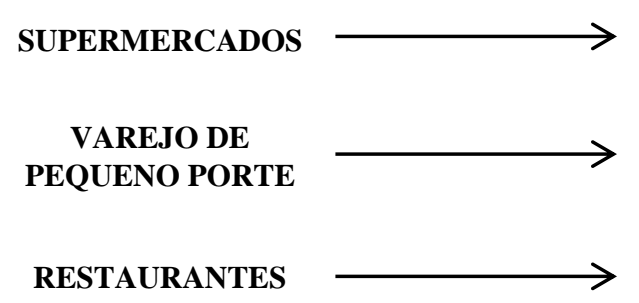

PRODUTOR FORNECEDOR DE ORGÂNICOS

PRODUTOR FORNECEDOR DE ORGÂNICOS

PRODUTOR FORNECEDOR DE ORGÂNICOS

Fonte: Desenvolvido pelo autor.

As díades conformadas pelas partes envolvidas foram identificadas como: díade $\mathrm{S}_{\mathrm{P}}$ (relação comercial supermercados - produtores fornecedores de orgânicos): díade $V_{P}$ (relação comercial varejo de pequeno porte - produtores fornecedores de orgânicos); e díade $R_{P}$ (relação comercial restaurantes - produtores fornecedores de orgânicos) (Figura 18). Foram contemplados 2 relacionamentos comerciais para a díade $S_{P}$ (relação comercial com dois produtores fornecedores de orgânicos); e 1 relacionamento comercial tanto para a díade $V_{P}$, quanto para a $\mathrm{R}_{\mathrm{P}}$ (relação comercial com um produtor fornecedor de orgânicos).

\section{Díade $S_{P}$}

Foram analisados 8 relacionamentos comercias, 2 para cada supermercado (Quadro 22). De acordo com os dados obtidos, com o passar do tempo, o relacionamento comercial 
entre eles e seus fornecedores (produtores de orgânicos) tem alcançado características de relacionamentos mistos, baseados na criação e conservação de confiança entre as duas partes, mas que envolvem a utilização de salvaguardas formais (a descrição do relacionamento comercial foi apresentada na descrição da unidade de analise Mercado cliente de produtos orgânicos - Supermercados, no numeral 4.2).

A confiança tem sido o resultado de um trabalho em conjunto focado na comunicação colaborativa referente ao comportamento da demanda do mercado, necessidades do mesmo, assim como de novos produtos e processos implantados na obtenção dos produtos. Participação que envolve ambas as partes por igual e que tem gerado troca de informação rica e novos conhecimentos (CAO; ZANG, 2011; DYER; SINGH, 1998; FERNANDES, 2013).

A confiança existente no relacionamento comercial (confiança baseada na benevolência) caracteriza-se por manter a expectativa de que nenhuma das partes atuará de forma oportunista (MAYER; DAVIS; SCHOORMAN, 1995; NOOTEBOOM, 1996). Tratase de um objetivo importante quando se trabalha na redução de ações que anteponham o oportunismo, nas atividades transacionais (WILLIAMSOM, 1981).

Além, observaram-se ações que esboçaram a existência de confiança focada nas competências internas de cada uma das partes envolvidas (MAYER; DAVIS; SCHOORMAN, 1995), isto é; os supermercados confiam nas competências dos produtores fornecedores de orgânicos, pois eles ofertam produtos de alta qualidade tanto nos componentes nutricionais, quanto na aparência e apresentação, qualidade que pode ser verificada graças à certificação com selo orgânico que possuem os seus fornecedores (Quadro 22).

“... a loja tem confiança nas qualidades intrínsecas dos produtos, e isso é graças à exigência que nós temos em relação à certificação orgânica com selo; e temos confiança em que os nossos fornecedores mantem qualidade na apresentação dos produtos, e isso você pode observá-lo nas embalagens adequadas e cômodas para os nossos clientes, o que faz com que nos mantenhamos nossa relação comercial com os nossos fornecedores. " $\mathrm{S}_{1}$.

Os depoimentos coletados junto aos representantes dos supermercados, também indicaram que tem confiança no poder de fornecimento de seus parceiros, sugerindo que mantem um nível de fornecimento estável e constante, durante todas as épocas do ano (Quadro 22). 
“... os nossos fornecedores mantem a frequência de fornecimento, ainda nas épocas mais dificeis do ano, e isso é difícil de achar hoje." $\mathrm{S}_{4}$.

\section{Quadro 22 - Criação de valor no relacionamento mercado cliente - produtores fornecedores.}

\begin{tabular}{|c|c|c|c|c|c|}
\hline $\begin{array}{l}\text { Categoria do } \\
\text { relacionamento } \\
\text { comercial }\end{array}$ & $\begin{array}{c}\text { Relacionamento } \\
\text { comercial }\end{array}$ & $\begin{array}{c}\mathrm{N}^{\circ} \text { de } \\
\text { relacionamentos } \\
\text { comerciais }\end{array}$ & Valor criado para o cliente & Valor criado para o produtor & $\begin{array}{l}\text { Indicador do } \\
\text { valor criado }\end{array}$ \\
\hline Mistos & $\mathrm{S}_{\mathrm{p}}$ & 8 & $\begin{array}{l}\text { Atendimento da demanda de } \\
\text { orgânicos; Variedade de produtos; } \\
\text { Inovação; Constante volume e } \\
\text { qualidade de fornecimento. }\end{array}$ & $\begin{array}{c}\text { Incremento das vendas; } \\
\text { sustentabilidade; Reputação; } \\
\text { Segurança do mercado e de } \\
\text { preços. }\end{array}$ & $\mathrm{DP}+\mathrm{CO}$ \\
\hline Mistos & $V_{P}+R_{P}$ & 7 & $\begin{array}{c}\text { Variedade de produtos; Qualidade; } \\
\text { Confiabilidade. }\end{array}$ & $\begin{array}{l}\text { Fidelidade; Incremento do } \\
\text { volume fornecido; Segurança do } \\
\text { mercado e de preços. }\end{array}$ & $\mathrm{DP}+\mathrm{CO}$ \\
\hline Transacional & $\mathrm{R}_{\mathrm{p}}$ & 1 & - & - & - \\
\hline
\end{tabular}

DP: Disposição a pagar por o produto; CO: Redução do custo de oportunidade; $\mathbf{S}_{\mathbf{P}}$ : relação comercial entre os Supermercados e os produtores-fornecedores; $\mathbf{V}_{\mathbf{P}}$ : relação comercial entre o Varejo de pequeno porte e os produtores-fornecedores; $\mathbf{R}_{\mathbf{P}}$ : relação comercial entre os Restaurantes e os produtores-fornecedores.

Fonte: Desenvolvido pelo autor.

Já os produtores fornecedores pressupõem um desempenho competente mercadológico no setor de orgânicos por parte dos supermercados. Não obstante, evidenciaram-se características transacionais no relacionamento comercial devido principalmente à existência de contratos formais utilizados como salvaguardas (DYER; CHO; CHU, 1998; FERNANDES, 2013; POPPO; ZENGER, 2002; WILLIAMSON, 1981).

O valor criado por meio dos relacionamentos comerciais mistos evidenciados na díade $S_{\mathrm{P}}$ foi identificado no aumento da disposição a pagar (DP) por parte dos supermercados e numa redução do custo de oportunidade do fornecedor (BRANDENBURGER; STUART, 1996) (Quadro 22). O valor criado para os produtores fornecedores identificou-se no incremento do volume fornecido, na segurança do mercado, nos preços justos e no ganho de reputação no segmento de mercado dirigido à comercialização de produtos orgânicos certificados (Quadro 22). Em relação ao valor criado para os supermercados, foi encontrado presente no atendimento da demanda de produtos orgânicos inovadores, numa oferta variada 
de produtos de qualidade comprovada, com uma frequência adequada às necessidades e com um volume de fornecimento constante durante todo o ano (Quadro 22).

Díades $V_{P}$ e $R_{P}$.

Foram analisados 8 relacionamentos comercias, 3 entre o grupo de varejo de pequeno porte e seus fornecedores; e 5 entre os restaurantes e seus fornecedores (Quadro 22). Nas díades $V_{P}$ e $R_{P}$ foram evidenciados relacionamentos comerciais predominantemente colaborativos, a exceção de um caso pertencente ao grupo de restaurantes, que evidenciou uma relação comercial com seus fornecedores meramente transacional, com baixo conteúdo relacional, do tipo salvaguardas formais como contratos rígidos e detalhados (DYER; CHO; CHU, 1998; FERNANDES, 2013; POPPO; ZENGER, 2002; WILLIAMSON, 1981).

De acordo com os dados obtidos, a totalidade das unidades conformadoras do grupo de varejo de pequeno porte (3/3) e 4 restaurantes (4/5) apresentaram relacionamentos comerciais fortemente marcados com características colaborativa, baseados em confiança mutua, comunicação colaborativa, troca de informação e compartilhamento de conhecimentos (CAO; ZHANG, 2011; DYER; SINGH, 1998; FERNANDES, 2013; STANK; DITTMANN; AUTRY, 2011). Como já descrito em seções anteriores, ao se complementar estas características dentro de uma relação comercial, gera ganhos e vantagens competitivas (CAO; ZHANG, 2011; CARR; PEARSON, 1999; DYER; SINGH, 1998; MAYER; DAVIS; SCHOORMAN, 1995).

Foi identificado o valor criado através dos relacionamentos comerciais colaborativos no aumento da disposição a pagar (DP) por parte dos restaurantes e dos mercadinhos, lojas e varejões; mesmo como na redução do custo de oportunidade por parte do fornecedor (BRANDENBURGER; STUART, 1996) (Quadro 22). De acordo com os grupos varejo de pequeno porte e restaurantes, o valor criado para os produtores fornecedores é refletido na fidelidade por parte dos agentes intermediários, no incremento do volume de compra, na segurança do mercado e nos preços justos (Quadro 22).

Quanto que o valor criado para os dois agentes intermediários analisados, este se reflete tanto na variedade de pratos que podem ser oferecidos pelos restaurantes, quanto na variedade de produtos com processamento mínimo ofertados pelo varejo de pequeno porte, isto: levando em conta a variedade de produtos fornecida pelos produtores. Outros aspetos nos que foi possível evidenciar o valor criado para os grupos de varejo de pequeno porte e 
restaurantes, referem-se à qualidade dos produtos e à confiabilidade de que estes são obtidos mediante o sistema orgânico produtivo (Quadro 22).

Não foi possível evidenciar processos desenvolvidos que influenciaram no custo de oportunidade nem na disposição a pagar, através dos relacionamentos comerciais transacionais entre $\mathrm{o} \mathrm{R}_{3}$ e os seus produtores fornecedores. Nesta relação comercial só identificaram-se atividades transacionais com foco na decisão do restaurante sobre o que comprar. A decisão vem a ser definida pela busca do equilíbrio entre os custos internos do restaurante e os custos de aquisição dos produtos orgânicos. Este pressuposto é apresentado por Coase (1937) ao referir-se à TCT, argumentando que a existência de uma empresa é resultante dos mecanismos de preços que fazem com que a empresa tenda a expandir até que seus custos para produzir determinado produto ou serviço dentro da organização se igualem aos custos de adquirir o mesmo de terceiros (COASE, 1937). Assim, evidenciou-se que o $\mathrm{R}_{3}$ não tinha um produtor fornecedor fixo, exibindo relacionamentos comerciais transacionais baseados na constate busca das melhores ofertas focadas no preço.

Processos de criação de valor: percepção do mercado cliente.

Nesta seção apresentam-se os processos de criação de valor identificados nos relacionamentos comerciais nas três díades analisadas $\left(\mathrm{S}_{\mathrm{P}} ; \mathrm{V}_{\mathrm{P}} ; \mathrm{R}_{\mathrm{P}}\right)$. Foram levadas em conta as três etapas propostas na seção "Processos de criação de valor: percepção do produtor rural": início, desenvolvimento e benefícios. Além, do mais são apresentados os benefícios advindos desses processos $\left(\mathrm{V}_{\mathrm{C}}\right)$ para os produtores fornecedores desde a visão do mercado cliente, refletidos na redução do custo de oportunidade (CO); e/ou para o mercado cliente, refletido no aumento da disposição a pagar (DP) (BRANDENBURGER; STUART, 1996).

\section{Díades $V_{P}$ e $R_{P}$}

Evidenciou-se que o processo de criação de valor presente nas relações comerciais identificadas nas díades $V_{P}$ e $R_{P}$ tem como mecanismo de criação de valor o denominado "Construindo Confiança" (Figura 16). Tendo seu inicio na participação bilateral entre os envolvidos no relacionamento comercial, constatando-se uma proximidade que obedece à comunicação colaborativa (Figura 16). O inicio foi dado nos contextos de inovação e 
necessidade; salientando-se a existência de uma governança colaborativa em conjunto com a troca de informações (teoria RV).

A confiança na relação comercial é referente à ausência de contratos formais, baseada nas competências dos produtores fornecedores rurais por parte dos clientes, e na confiança (benevolência) que tem tanto o mercado cliente quanto os fornecedores em que serão sempre obtidos benefícios econômicos, além da redução da incerteza e de ações oportunistas (DYER; SINGH, 1998; HOBBS, 1996; MAYER; DAVIS; SCHOORMAN, 1995; WILLIAMSOM, 1981) (Figura 16).

A confiança baseada em benevolência é uma constante nos relacionamentos comerciais nas díades analisadas, característica que ajudou a enquadra-las neste mecanismo de criação de valor. Na etapa de entrega dos produtos, a confiança e o fato de assumir os riscos por ambas as partes envolvidas, são caraterísticas presentes e constantes nos relacionamentos comerciais identificados. Foi identificado finalmente o processo de envolvimento caracterizado pela comunicação colaborativa, troca de informação e compartilhamento de conhecimentos (DYER; SINGH, 1998). A materialização do processo reflete-se no aumento da disposição a pagar e na redução do custo de oportunidade (BRANDENBURGER; STUART, 1996).

\section{Díade $S_{P}$}

Por meio da análise dos processos de criação de valor presente nas relações comerciais da díade $S_{P}$ foi identificado o mecanismo de criação de valor denominado "Benefícios mútuos" (Figura 16). Os iniciadores do processo de criação de valor envolvidos referem-se aos produtores fornecedores e o agente intermediário (supermercado). Neste caso, foi identificada uma complementariedade de recursos em pleno (DYER; SINGH, 1998), devido ao Know-how (MIOR, 2007) próprio dos produtores fornecedores, e no caso dos supermercados oferecem a segurança de preços e de mercado. Encontrou-se uma forte influencia de governança interna e troca de informação (DYER; SINGH, 1998). O contexto de necessidade que teve o início do relacionamento comercial foi impulsionado tanto pelos supermercados, quanto pelos produtores fornecedores de orgânicos.

No caso dos supermercados, comprovou-se uma necessidade de produtos de qualidade certificada, que cumpriram com volumes e frequência de fornecimento constante, e que além apresentaram atitudes baseadas na inovação que visaram a busca de soluções às exigências do 
mercado consumidor. Quanto aos produtores fornecedores de produtos orgânicos, a relação está baseada na identificação de um mercado seguro para os seus produtos e com preços mais elevados que os praticados no mercado de produtos convencionais.

O mecanismo também envolve a confiança como elemento primordial no processo de criação de valor; elemento que seria identificado como baseado tanto na benevolência, tendo em conta que se trata de uma relação comercial que envolve tanto investimentos, quanto complementariedade das capacidades intrínsecas de cada uma das partes, reduzindo assim os riscos, obtendo benefícios compartilhados, gerando um resultado refletido na redução dos custos de transação (CAO; ZHANG, 2011; DYER; SINGH, 1998). Conseguiu-se também identificar procedimentos que contribuem para reduzir ao mínimo os riscos nas transações; aqueles procedimentos têm como suporte salvaguardas formais referentes a contratos, que estipulam determinados compromissos que deverão ser cumpridos por ambas as partes conformadoras do relacionamento comercial (FERNANDES, 2013; RINDFLEISCH; HEIDE, 1997). Assim, foi identificado um nível de incerteza e oportunismo baixos (HOBBS, 1996; WILLIAMSOM, 1991).

No momento da realização da transação, as duas partes assumem um nível de risco relacionado com aceitação de que as informações que foram fornecidas respeito ao produto (sistema de produção e qualidade) e respeito ao mercado (preços no mercado e demanda) são verdadeiros. Os riscos envolvidos na negociação são reduzidos por médio das salvaguardas já mencionadas (HOBBS, 1996; RINDFLEISCH; HEIDE, 1997; WILLIAMSOM, 1991). Finalmente evidenciou-se um processo de envolvimento caracterizado por comunicação colaborativa, intercâmbio de informações e de conhecimentos (DYER; SINGH, 1998). A materialização do processo é identificada no aumento da disposição a pagar e na redução do custo de oportunidade (BRANDENBURGER; STUART, 1996). 


\section{CONCLUSÕES E RECOMENDAÇÕES}

A presente pesquisa objetivou identificar as estratégias adotadas por um grupo de produtores rurais pertencentes ao sistema de produção orgânica, para criar valor nos relacionamentos comerciais produtor - cliente, a partir da adequação à legislação orgânica e ambiental. Nesse sentido, o trabalho teve como iniciador o pressuposto de que os produtores rurais sob sistemas de produção orgânica, alocados nas bacias hidrográficas dos rios Maranhão e São Bartolomeu - DF, evidenciariam uma maior disposição a se enquadrar na legislação ambiental e a utilizar esta característica como ferramenta para criar valor nos relacionamentos comerciais produtor-cliente visando obter vantagens competitivas no mercado.

Para isso, num primeiro momento foi utilizada uma metodologia de quantificação do processo de transição agroecológica em dois grupos de propriedades rurais nomeados de Grupo A e B, o que permitiu a identificação e classificação das propriedades rurais em níveis de transição agroecológica, além da aplicação de um formulário com questões referentes a aspectos da legislação ambiental especificamente no referente ao conhecimento e à adequação da legislação ambiental.

Desta forma, encontrou-se que o grupo A, obtiveram em média valores dos sub-níveis de transição agroecológica 2 e 3, significativamente superiores, comprovando que a as propriedades pertencentes a este grupo estão avançando positiva e efetivamente no redesenho dos componentes do agroecossistema resultado de um alto grau de associativismo que lhes permite melhores planejamentos dos sistemas produtivos. A totalidade dos produtores pertencentes ao grupo A (8/8) já estão no terceiro nível de transição agroecológica, estágio este que recebe o nome de redesenho dos agroecossistemas.

Para o caso do grupo B, as informações levantadas indicam que persistem deficiências referentes à substituição de insumos e defensivos sintéticos por insumos e defensivos de base ecológica. Encontraram-se também deficientes práticas de uso da biodiversidade funcional e de componentes da paisagem no manejo produtivo. Foi ainda de fundamental importância a constatação da não filiação ou participação dos produtores em entidades associativas ou cooperativas.

Constatou-se que como consequência das deficiências apresentadas, os produtores do grupo B ainda tendo presença nas feiras de produtores e nas compras públicas representadas pelo PAA, mantem problemas relacionados com os preços no mercado dos seus produtos. 
O respeito ao grau de conhecimento dos produtores rurais avaliados em relação à legislação ambiental encontrou-se um cenário bastante contundente. De acordo com os dados fornecidos pelos produtores, conseguiu-se identificar o desconhecimento, por parte dos produtores nos dois grupos (A e B), em relação à documentação exigida pela legislação como: a averbação das áreas de Reserva Legal e o licenciamento ambiental das propriedades. Da mesma forma foi identificado o desconhecimento em relação com os percentuais e limites das áreas de Reserva Legal e de Áreas de Preservação Permanente necessários para que cada propriedade se enquadrar na legislação ambiental. Mesmo que confirmada o desconhecimento da legislação ambiental brasileira por parte dos produtores, salienta-se que a totalidade dos produtores (16/16) reconhece a importância do meio ambiente e trabalham em pro da sua preservação e sustentabilidade.

Em relação à adequação à legislação ambiental, encontrou-se que a totalidade das propriedades pertencentes ao grupo A (8/8) e 3 das propriedades do grupo B (3/8), encontramse enquadrados na normativa no que diz respeito as percentual necessário ou mínimo exigido de áreas Reserva Legal. Dos 2 produtores com propriedades particulares do grupo B, só um enquadre-se dentro da legislação ambiental no referente às área de Reserva Legal.

No referente ao tamanho das Áreas de Preservação Permanente de hidrografia observou-se que o grupo A, ainda apresentando um déficit, tanto que para 6 das as propriedades do grupo B (6/8) não se aplica o referente às Áreas de Preservação Permanente por não ter interferência nos imóveis a hidrografia indicada pela cartografia oficial do DF. Encontrou-se que uma das duas propriedades restantes do grupo B, possui um déficit a ser recuperado em área de mata.

Quando identificados e analisados os mecanismos de criação de valor, utilizados pelos produtores a partir da adesão à legislação orgânica e ambiental nos relacionamentos comerciais produtor-cliente, o recorte analítico escolhido ajudou a identificar que em geral ambos os grupos de produtores evidenciaram indícios de vantagens competitivas identificadas nas fontes de valor interna, as quais foram definidas apartir da implantação de atividades e processos produtivos em consonância com a proteção e cuidado do ambiente em geral, assim como na adoção de novas estratégias mercadológicas.

Finalmente, foram identificados dois mecanismos de criação de valor através dos relacionamentos comerciais: construído confiança e Benefícios mútuos; os quais puderam evidenciar o valor criado no aumento da disposição a pagar por parte dos consumidores e na redução do custo de oportunidade por parte dos produtores de orgânicos. 
De acordo com a percepção dos clientes (conformados por três grupos de intermediários: supermercados, varejo de pequeno porte e restaurantes) quanto à criação de valor, foram identificados e validados os dois mecanismos de criação evidenciados pelos produtores.

Sobressaiu a criação de valor focada no produtor fornecedor (comum para os três grupos) indicando que os agentes intermediários priorizam o trabalho conjunto visando obter benefícios mútuos

Nos processos de criação de valor: percepção do mercado cliente, para as díades $\mathrm{R}_{\mathrm{F}} \mathrm{e}$ $\mathrm{V}_{\mathrm{F}}$ foi identificado o mecanismo de criação de valor denominado de "Construindo Confiança" e para a díade $\mathrm{S}_{\mathrm{F}}$ o mecanismo de criação de valor denominado "Beneficios mútuos". No caso das díades analisadas entre os supermercados e os fornecedores, comprovou-se uma necessidade de produtos de qualidade certificada, que cumpram com volumes e frequência de fornecimento constante, e que além apresentem atitudes inovadoras no processo da busca de soluções às necessidades do mercado consumidor.

Por ultimo, as limitações encontradas na pesquisa estão relacionadas com diferentes fatores, dentre eles os mais importantes: i) não foi possível ter informação de produtores orgânicos certificados por auditoria com selo; ii) nenhum dos produtores avaliados teve relação comercial com os mercados formais o que não permitiu fazer uma comparação incluindo este atores; iii) foram analisadas somente duas bacias hidrográficas, a pesquisa poderia alcançar mais profundidade se um número maior de casos fossem levados em conta.

Os resultados que foram obtidos esboçam alguns aspetos que mantem ainda lacunas de produção de conhecimento, porém, partindo do presente estudo são propostas orientações para futuras investigações. Num primeiro momento, sugere-se o desenvolvimento de pesquisas com produtores certificados por auditoria e que tenham uma forte presença no mercado orgânico, visando elucidar as estratégias adotadas para manter os relacionamentos comerciais e de criação de valor a partir deles. É oportuno sugerir novas pesquisas que testem os relacionamentos comerciais analisados no presente trabalho, procurando um maior aprofundamento das teorias de VR e TCT. Finalmente sugere-se que seja replicado o presente modelo de pesquisa em diferentes regiões e realidades sociais visando testar e generalizar os resultados vislumbrados. 


\section{REFERENCIAS}

AGNE, L. C.; WAQUI, P. D. Agroindústrias rurais familiares: estratégias de mercado na região do COREDE Jacuí Centro/RS. Revista do programa de pós-graduação em turismo. Universidade de Caixas do Sul, n. 2, v. 3, 2011.

ALMEIDA, F. M. Caracterização e análise das certificações (conformidade) de unidades de produção orgânica no distrito federal. 2013. 87 f. Dissertação (Mestrado em Agronegócios) - Faculdade de agronomia e medicina veterinária, Brasília/DF, 2013.

ALTIERI, M. A.; NICHOLLS, C. I. Agroecologia: Resgatando a agricultura orgânica a partir de um modelo industrial de produção e distribuição. Ciência \& ambiente, 2003. 12 f.

AQUINO, A. M; DE ASSIS, R. L. Agroecologia: princípios e técnicas para uma agricultura orgânica sustentável. Brasília, DF. Embrapa Informação tecnológica, 2005. 517 p.

BARDIN, L. Análise de conteúdo. Lisboa, Portugal: Edições 70, 1977.

BARNEY, J. B., Firm Resources and Sustained Competitive Advantage. Journal of Management, n. 1, v. 17, p. 99-120, 1991.

BONOMA, T.V. Case research in marketing: opportunities, problems, and a process. Journal of marketing research, n. 2, v. 22, p. 199-208, 1985.

BRANDENBURGER, A. M.; STUART JR., H. W., Value-Based Business Strategy. Journal of Economics \& Management Strategy. Boston, M. A.: Harvard Bussines School. v. 5, n. 1, p. 5-24, 1996.

BRASIL. Decreto Federal $\mathbf{n}^{\mathbf{0}} \mathbf{6 . 3 2 3}$, de 27 de dezembro de 2007. Regulamenta a Lei no 10.831, de 23 de dezembro de 2003. Brasília, 27 de dezembro de 2007, p. 1.

Decreto Federal $\mathbf{n}^{\circ}$ 6.514, de 22 de julho de 2008. Dispõe sobre as infrações e sanções administrativas ao meio ambiente, estabelece o processo administrativo federal para apuração destas infrações, e dá outras providências. Brasília, 22 de julho de 2008, p. 1. 2008f.

Decreto Federal $\mathbf{n}^{\mathbf{0}}$ 7.029, de 10 de dezembro de 2009. Que institui o Programa Federal de Apoio à Regularização Ambiental de Imóveis Rurais, denominado "Programa Mais Ambiente", e dá outras providências. Brasília, 10 de dezembro de 2009, p. 1. 2009h. 
Instrução normativa $n^{\circ} 3$, de 8 de setembro de 2009. Ministério do Meio Ambiente. Gabinete do ministro.Diário oficial da União, seção 1, n ${ }^{\circ}$ 172. Brasília, 2009a.

Instrução normativa $\mathbf{n}^{\circ} \mathbf{4}$, de 8 de setembro de 2009. Dispõe sobre procedimentos técnicos para a utilização da vegetação da Reserva Legal sob regime de manejo florestal sustentável, e dá outras providências. Ministério do Meio Ambiente. Gabinete do ministro. Diário oficial da União, seção 1, n 172. Brasília, 2009b.

Instrução normativa $\mathbf{n}^{\circ} \mathbf{5}$, de 8 de setembro de 2009. Dispõe sobre os procedimentos metodológicos para restauração e recuperação das Áreas de Preservação Permanentes e da Reserva Legal instituídas pela Lei no 4.771, de 15 de setembro de 1965. Gabinete do ministro. Ministério do Meio Ambiente.Diário oficial da União, seção 1, ${ }^{\circ} 172$. Brasília, 2009c.

Instrução normativa n. ${ }^{\circ}$, de 17 de maio de 1999. O Ministro de Estado da Agricultura e do Abastecimento. Dispõe sobre normas para a produção de produtos orgânicos vegetais e animais. Brasília, 1999.

Instrução normativa $n^{\circ}$ 46, de 06 de outubro de 2011. Ministério da agricultura, pecuária e abastecimento. Gabinete do ministro. Brasília, 6 de outubro de 2011, p. 32.

Lei Federal $n^{\circ}$ 9.605 de 12 de fevereiro de 1988. Dispõe sobre as sanções penais e administrativas derivadas de condutas e atividades lesivas ao meio ambiente, e dá outras providências. Brasília, 12 de fevereiro de 1988, p. 1.

Lei Federal $n^{0}$ 12.349, de 15 de dezembro de 2010. Conversão da Medida Provisória $n^{\circ}$ 495/2010. Altera as Leis nos 8.666, de 21 de junho de 1993, 8.958, de 20 de dezembro de 1994, e 10.973, de 2 de dezembro de 2004; e revoga o 1 o do art. 2 o da Lei no 11.273, de 6 de fevereiro de 2006. 2010k.

Lei Federal $\mathbf{n}^{\circ}$ 10.831. Brasília, 2003. Dispõe sobre a agricultura orgânica e dá outras providências. Diário Oficial da União de 24/12/2003, Seção 1, Página 8. 2003.

Lei federal $\mathbf{n}^{\mathbf{0}}$. 6.938 de 31 de agosto de 1981. Já alterada pela Lei $\mathrm{n}^{\circ} 7804$ de 18 de julho de 1989. Dispõe sobre a Política Nacional do Meio Ambiente, seus fins e mecanismos de formulação e aplicação, e dá outras providências. Brasília, Fonte D.O.U. Seção I, v. 119, p. 16509, FASC. 167, set. 1981.

Lei $n^{\circ}$ 9.393, de 19 de dezembro de 1996. Dispõe sobre o Imposto sobre a Propriedade Territorial Rural - ITR, sobre pagamento da dívida representada por títulos da dívida agrária e dá outras providências. Brasília, p. 35, set. 2002. 
Lei $\mathbf{n}^{\circ}$ 12.651, de 25 de Maio de 2012. Novo código Florestal. Dispõe sobre a proteção da vegetação nativa; altera as Leis $n^{\circ}$ s 6.938, de 31 de agosto de 1981, 9.393, de 19 de dezembro de 1996, e 11.428, de 22 de dezembro de 2006; revoga as Lei $\mathrm{n}^{\circ} \mathrm{s} 4.771$, de 15 de setembro de 1965, e 7.754, de 14 de abril de 1989, e a Medida Provisória no 2.166- 67, de 24 de agosto de 2001; e dá outras providências. Brasília, 2012.

Portaria $\mathrm{n}^{\circ}$ 158, de 8 de julho de 2004. Ministério da agricultura, pecuária e abastecimento. Brasília: Gabinete do ministro, 8 de julho de, p. 1. 2004.

Resolução $\mathbf{n}^{\circ}$ 387, de 27 de dezembro de 2006. Estabelece procedimentos para o Licenciamento Ambiental de Projetos de Assentamentos de Reforma Agrária, e dá outras providências. Ministério do Meio Ambiente. Conselho Nacional do Meio Ambiente. Brasília, p. $15,2006 \mathrm{e}$.

Resolução $\mathbf{n}^{\circ}$ 425, de 25 de maio de 2010. Dispõe sobre critérios para a caracterização de atividades e empreendimentos agropecuários sustentáveis do agricultor familiar, empreendedor rural familiar, e dos povos e comunidades tradicionais como de interesse social para fins de produção, intervenção e recuperação de Áreas de Preservação Permanente e outras de uso limitado. Brasília. Publicado no DOU n ${ }^{\circ} 100$, de 27 de março de 2010, p. 53. 2010k.

Resolução CONAMA $\mathbf{n}^{\circ}$ 237, de 19 de dezembro de 1997. Dispõe sobre a revisão e complementação dos procedimentos e critérios utilizados para o licenciamento ambiental. Brasília, 19 de dezembro de 1997, p. 1.

Resolução CONAMA n 303, de 20 de março de 2002. Dispõe sobre parâmetros, definições e limites de Áreas de Preservação Permanente. Brasília, 20 de março de 2002, f. 1.

Resolução CONAMA no 369, de 28 de março de 2006. Em atendimento à Lei 4.771, de 15 de setembro de 1965, altera pela MP 2.166/2001. Dispõe sobre os casos excepcionais, de utilidade pública, interesse social ou baixo impacto ambiental, que possibilitam a intervenção ou supressão de vegetação em Área de Preservação PermanenteAPP. Áreas protegidas - Áreas de Preservação Permanente. Brasília. Publicada no DOU n ${ }^{\circ}$ 61, de 29 de março de 2006, seção 1, f. 150 - 151. 2006d.

Resolução CONAMA no 429, de 28 de fevereiro de 2011. Dispõe sobre a metodologia de recuperação das Áreas de Preservação Permanente - APPs. Brasília, 2011.

CAO, M.; ZHANG, Q. Supply chain collaboration: Impact on collaborative advantage and firm performance. Journal of Operations Management, v. 29, n. 3, p. 163-180, 2011. 
CAPORAL, F. R. Agroecologia: uma nova ciência para apoiar a transição a agriculturas mais sustentáveis. Brasília, 2009. 30 p.

CARR, A. S.; PEARSON, J. N., Strategically managed buyer-supplier relationships and performance outcomes. Journal of Operations Management, v. 17, n. 5, p. 497-519, 1999.

CARVALHO, M. S. N. et al. Plano territorial de desenvolvimento rural sustentável Território Águas Emendadas - DF. Ministério do Desenvolvimento Agrário - MDA. 122 P. Novembro de 2006.

COASE, R. H. The nature of the firm. Economica, New Series. The Suntory and Toyota International Centres for Economics and Related Disciplines, v. 4, p. 386-405, 1937.

CODEX ALIMENTARIUS. Programa Conjunto FAO/OMS sobre Normas Alimentarias: Alimentos producidos organicamente. 2 Ed. Roma, 2005. 65 p.

COMPANHIA DE PLANEJAMENTO DO DISTRITO FEDERAL (CODEPLAN). Terracap. Aerofoto, 2013. Disponível em: <http://ortofoto.mapa.codeplan.df.gov.br/demo/tms> Acesso em: 123 de sep. 2013.

DYER, J. H.; CHO, D. S.; CHU, W. Strategic supplier segmentation: the next "best practice" in supply chain management. California management review. university of California, n. 2, v. 40, 1998. f $56-77$.

.; SINGH, H., The Relational View: Cooperative Strategy and Sources of Interorganizational Competitive Advantage. The Academy of Management Review, v.23, n. 4, p. 660-679, 1998.

ECOLEX. The gateway to enviromental Law. Disponível em: <http://translate.google.com.br/translate?hl=es\&sl=en\&u=http://www.ecolex.org/\&prev=/sear ch\%3Fq\%3DECOLEX\%26biw\%3D1024\%26bih\%3D499> Acesso em: 10 de jun. 2013.

EDWARDS, T.; BATTISTI, G. NEELY, A. Value creation and the UK economy: a review of strategic options. International Journal of Management Review. v. 5, n. 6, p. 191-213. 2004.

EISENHARDT, K. M.; SCHOOHOVEN, C. B. Strategic Alliance Formation. Organization Science, v. 7, n. 2, Mar.-Apr. 1996. 
ELZAKKER, B, V.; EYHORN, F. La guía de negocios orgánicos. Desarrollar cadenas de valor sostenibles con pequeños agricultores. IFOAM. 174 f. 2010.

EMPRESA BRASILEIRA DE PESQUISA AGROPECUÁRIA (EMBRAPA - Brasília, DF: Embrapa Informação Tecnológica). Ministério da Agricultura, Pecuária e Abastecimento. Marco referencial em agroecologia. 2006. P. 70.

EMPRESA DE ASISTENCIA TÉCNICA E EXTENSÃO RURAL DO DISTRITO FEDERAL (EMATER-DF). Emater promove desenvolvimento de assentamento. Folha online EMATER Noticias. Brasília, 2013. Disponível em: <http://www.emater.df.gov.br/index.php?option=com_content\&view=article\&id=746:ematerpromove-desenvolvimento-de-assentamento\&catid=47:noticias\&Itemid=125> Acesso: 26 ago. 14

FAOLEX. Oficina Jurídica. Disponível em: <http://faolex.fao.org/faolex_spa/> Acesso em: 3 jul. 2013.

FEISTAUER, D. Adequação à legislação ambiental de pequenas propriedades rurais conduzidas em sistema orgânico ou convencional no território portal da Amazônia mato grosso. 2012. 133 f. Dissertação (Mestrado em Agroecossistemas) - Centro de Ciências Agrárias, Universidade Federal de Santa Catarina, Florianópolis, 2012.

FERNANDES, A. R. A criação de valor nos relacionamentos com fornecedores e clientes: um estudo no setor de embalagens. São Paulo. 2013. 155 f. Tese (Mestre em Administração de Empresas). Escola de Administração de Empresas de São Paulo, Fundação Getúlio Vargas. São Paulo, 2013.

FERNANDES, M.G.P. Estatística Aplicada. Universidade do Minho, Braga. 1999, 299 p.

FIGUEIREDO, E. A. P. de; SOARES, J. P. G. Sistemas orgânicos de produção animal: dimensões técnicas e econômicas. In: REUNIÃO ANUAL DA SOCIEDADE BRASILEIRA DE ZOOTECNIA, 49. 2012, Brasília. A produção animal no mundo em transformação: anais. Brasília, DF: SBZ, 2012. 1 CD-ROM.

FONSECA, J. J. S. Metodologia da pesquisa científica. Curso de especialização em comunidades virtuais de aprendizagem - informática educativa. Fortaleza: UECE, 2002.

FONSECA, M. F. et al. Agricultura orgânica. Introdução às normas, regulamentos técnicos e critérios para acesso aos mercados dos produtos orgânicos no brasil. Manual técnico 19. Niterói - RJ, 2009. 
GARBIN, V.H. et al. A. Plano territorial de desenvolvimento sustentável do Território Portal da Amazônia - MT. Ministério do Desenvolvimento Agrário - MDA. 61 p. 2006.

GAZOLLA, M. et al. Agregação de valor nas agroindústrias rurais: uma análise com base nos dados do censo agropecuário. Revista paranaense de desenvolvimento, Curitiba, $\mathrm{n}^{\circ} 122$, p.241-262, jan./jun. 2012.

GEORGE, A. L.; BENNETT, A. Case studies and theory development in the Social Sciences. Cambridge, Massachusetts: The MIT Press, 2005.

GHEMAWAT, P.; RIVKIN, J. W., Creating Competitive Advantage, Boston, Harvard Business School Note, 21 p., 2006.

GIL, A. C. Como elaborar projetos de pesquisa. 4. ed. São Paulo: Atlas, 2002. 176 p.

GLEISMAN, S. R.; Agroecologia: processos ecológicos em agricultura. Porto Alegre, 2 ed. 2000. 653 p.

GODOY, C. M. T.; et. al. A Legislação ambiental e os dilemas da agricultura familiar. VI congresso brasileiro de agroecologia. II congresso Latino Americano de agroecologia. Curitiba, v.4, n² 2, p. 913-916, nov, 2009.

; WIZNIEWSKY J. G. Sustentabilidade ambiental através do conhecimento e da informação. Rev. Elet. em Gestão, Educação e Tecnologia Ambiental REGET/UFSM. v. 11, nº 11, p. 2280-2290, jun, 2013.

GRANT, R. M. The resource-based theory of competitive advantage: implications of strategy formulation. California Management Review, v. 33, n. 3, p. 114 -135, 1991.

HILL, T. Manufacturing strategy - Text and Cases. Macmillan, London.2000.

HOBBS, J. E. A transaction cost approach to supply chain management. Supply chain management, v. 1, n. 2, p. 15-27, 1996.

HOLCOMB, T. R.; HITT, M. A. Toward a model of strategic outsourcing. Journal of Operations Management. Texas A\&M University, Mays Business School, Department of Management. p. 464-481, 2007. 
HONDA, S. Oportunidades e desafios. In: FERRARI. M. S. Espaço orgânico \& natural. Maior conhecimento, melhores resultados. ed. 2. 2012.

HOWARD, A. An agricultural testament. Online library. Jurney to forever. Copyright 1943 by Oxford University Press, Inc. New York and London. 1943. 228 p.

INSTITUTO BRASÍLIA AMBIENTAL (IBRAM) GDF. Bacias do DF. Novembro 2012. Disponível em: <http://www.ibram.df.gov.br/informacoes/recursos-hidricos.html> Acesso em: 22 Agos. 2014.

INTERNATIONAL FEDERATION OF ORGANIC AGRICULTURE MOVEMENTS (IFOAM) Definition of organic agriculture. 2008. Disponível em: $<$ http://translate.google.com.br/translate?hl=ptBR\&sl=en\&tl=es\&u=http\%3A\%2F\%2Finfohu

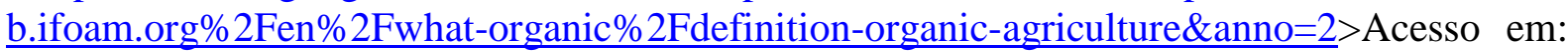
01 Agos. 2014.

Família

de normas.

2013.

Disponível

em:

<http://translate.google.com.br/translate?hl=es\&sl=en\&u=http://www.ifoam.org/\&prev=/sear ch\%3Fq\%3DIFOAM\%26biw\%3D1024\%26bih\%3D499>. Acesso em: 28 de jun. 2013.

.What is agriculture organic: History, pioneers. 2014a Disponível em: < http://infohub.ifoam.org/en/history/pioneers> Acesso: 06 jun. 2014.

.What do we do: Our strategy. 2014b Disponível em: < http://infohub.ifoam.org/en/history/pioneers> Acesso: 06 jun. 2014.

JESUS, E. L. Diferentes abordagens de Agricultura não convencional: História e filosofia. In: Agroecologia: princípios e técnicas para uma agricultura orgânica sustentável. Brasília, DF: Embrapa Informação tecnológica, 2005. 517 p.

KETCHEN, D. J. HULT, G.T. Bridging organization theory and supply chain management: The case of best value supply chains. Journal of Operations Management, v.25, p. 573. 2007.

KHATOUNIAN, C. A. A reconstrução ecológica da agricultura. Botucatu: Agroecológica. Instituto Agronômico do Paraná. 2001. 345 p.

KLEDAL, P. R. The four food systems in developing countries and the challenges of modern supply chain inclusion for organic small-holders. Paper da International Rural network Conference na India. Udaipur 23-28 de Agosto. 2009. 
CÂMARA DOS DEPUTADOS - 2 ed. - Brasília : Câmara dos Deputados, Edições. Câmara, 2010. Série legislação; n. 45.967 p.

LEPAK, D. P. et al. Value Creation and Value Capture: A Multilevel Perspective. Academy of Management Review, v. 32, n. 1, p. 180-194, 2007.

MACENA, A. F. Pesquisa - O mercado brasileiro de produtos orgânicos. Inteligência Instituto de promoção de desenvolvimento (IPD Orgânicos). Curitiba. 2011. 41 f.

MACHADO, A.T.; SANTILI, J.; MAGALHÃES, R. A agrobiodiversidade com enfoque agroecológico: implicações conceituais e jurídicas. Embrapa Informação Tecnológica, Brasília - DF, 2008, 98 p.

MAGALHÃES, E. S. Agricultura orgânica no Distrito Federal: uma análise exploratória. Monografia (Especialista em gastronomia e segurança alimentar). 80 f. 2004. Centro de excelência em turismo da Universidade de Brasília. Brasília - DF, 2004

MAYER, R. C.; DAVIS, J. H.; SCHOORMAN, F. D. An integrative model of organizational trust. Academy of management review. n. 3, v. 20. F. $709-734.1995$

MEREDITH, J. R. Building operations management theory through case and field research. Journal of operations management, v. 16, $\mathrm{n}^{\circ}$ 4, p. 441-454, 1998.

MESQUITA, J. M. C. de; LARA, J. E.; SOUKI, G. Q. Impactos da estabilização monetária e da estratégia competitiva da indústria sobre o consumo de café torrado no Brasil. Organizações Rurais \& Agroindustriais. Lavras, v. 12, n. 3, p. 435-444. 2010.

MIGUEL, P. L. S. Criação e apropriação de valor em relacionamentos entre empresas compradoras e fornecedoras. Tese (Doutorado em Administração de Empresas) São Paulo, Brasil. 2012. 236 f. Escola de Administração de Empresas de São Paulo da Fundação Getulio Vargas. São Paulo, 2012.

MINISTERIO DE AGRICULTURA, PECUÁRIA E ABASTECIMENTO (MAPA). Agroecologia. Aumenta número de produtores de orgânicos no Brasil. 2014d. Disponível em:<http://www.agricultura.gov.br/comunicacao/noticias/2014/02/aumenta-numero-deprodutores-de-organicos-no-brasil > Acesso em: 23 abr. 2014.

04/06/2014.
. Cadastro nacional de produtores orgânicos. Data de atualização:
Consolidado, certificadoras e Opac. 
em:<http://www.agricultura.gov.br/desenvolvimento-sustentavel/organicos/cadastronacional> Acesso em: 4 Mai. 2014.

Legislação. 2014b. Disponível em:<http://www.agricultura.gov.br/desenvolvimento-sustentavel/organicos/legislacao> Acesso em: 4 de Junh. 2014.

• Regularização da Produção Orgânica. 2014e Disponível em: $<$ http://www.agricultura.gov.br/desenvolvimento-sustentavel/organicos/regularizacao producao-organica $>$ Acesso em: 4 de Junh. 2014.

Semana dos orgânicos. $10^{\mathrm{a}}$ edição. 2014c Disponível em: <http://www.agricultura.gov.br/comunicacao/noticias/2014/05/sao-paulo-tera-programacaojuntamente-com-a-bio-brasil-fair> Acesso em: 4 de Junh. 2014.

. Vegetal. Mato Grosso e Pará têm as maiores áreas de orgânicos do país. 2012. Disponível em: <http://www.agricultura.gov.br/comunicacao/noticias/2012/05/mato-grosso-epara-tem-as-maiores-areas-de-organicos-do-pais > Acesso em: 1 de Junh. 2014.

MIOR, L. C. Agricultura familiar, agroindústria e desenvolvimento territorial. Florianópolis: [UFSC], 2007. Colóquio Internacional sobre Desenvolvimento Rural Sustentável, 1. Disponível em: <http://www.cidts.ufsc.br/articles/Artrigo_Coloquio_\%20-_Mior.pdf> Acesso em: 6 de agosto, 2014..

MOREIRA, R. M. Da hegemonia do agronegócio à heterogeneidade restauradora da agroecologia: estratégias de fortalecimento da transição agroecológica na agricultura familiar camponesa do programa de extensão rural agroecológica de Botucatu e região Progera. Tese (Doutor em Agronomia) São Paulo, Brasil. 2012. 362 f. Programa Agroecologia, Sociologia e Desenvolvimento Rural Sustentável, Universidade de Córdoba. Córdoba, 2012.

Transição agroecológica: conceitos, bases sociais e a localidade de Botucatu/Sp - Brasil. 2003. 151 f. Dissertação (Maestria em Engenharia Agrícola). Faculdade de Engenharia Agrícola, Universidade Estadual de Campinas. Campinas - SP, 2003.

MOZZATO, A. R.; GRZYBOVSKI, D. Documentos e debates: análise de conteúdo como técnica de análise de dados qualitativos no campo da administração: potencial e desafios. RAC, Curitiba, v. 15, n. 4. p. 731-747, 2011. 
NOKE, H. e HUGHES, M. Clibing the value chain: strategies to create a new product development of new product capability in SMEs. International Journal of Production and Operations Management. v. 30, n. 2, p. 152. 2010.

NOOTEBOOM, B. Trust, opportunism and governance: a process and control mode. University of Groningen, the Netherlands, 1996. f. $985-1010$.

OLIVEIRA, D. C. Análise de conteúdo temático-categorial: uma proposta de sistematização. Rev. Enferm. UERJ, Rio de Janeiro, v. 16, n 4, p. 569-576. 2008.

ORGANIC MONITOR. The global Market for organic food and drink. Market growth. 2014. Disponível em: 〈http://www.organicmonitor.com> Acesso em: 2 jun. 2014.

ORMOND, J. G. P. et al. Agricultura orgânica: quando o passado é futuro. BNDES Setorial, Rio de Janeiro, n. 15, 2002. 32p.

PAIVA, E. L. e VIEIRA, L. M. Strategic choices and operations strategy: a multiple cases study. International Journal of Services and Operations Management. Geneve, v. 10, n.2, p. $119-135,2011$

PARMIGIANI, A.; MITCHELL, W. Complementarity, capabilities, and the boundaries of the firm: the impact of within-firm and interfirm expertise on concurrent sourcing of complementary components. Strategic Management Journal. Strat. Mgmt. J. p. 1 - 27. 2009.

PEDROSO, R. O.; BUENO, W. S. Certificação de produtos orgânicos. In: PEDROSO, R. O. et al. Produção Orgânica de Citros no Rio Grande do Sul. Pelotas, RS. Embrapa Clima Temperado. 2010. cap. 3, p. $40-46$.

PETERAF, M. A.; BARNEY, J. B., Unraveling the Resource-Based Tangle. Managerial and Decision Economics, v. 24, n. 4, p. 309-323, 2003.

POPPO, L.; ZENGER, T. Do formal contracts and relational governance function as substitutes or complements? Strategic Management Journal, v. 23, n. 8, p. 707-725, 2002.

PORTAL DA CIDADANIA. Territórios da cidadania. 2014. Disponível em: <http://www.territoriosdacidadania.gov.br/dotlrn/clubs/territriosrurais/xowiki/oprograma\#> Acesso: Agosto, 2014. 
PORTER, M. Competitive Strategy, The Free Press, New York. 1985.

PORTER, M. E.; KRAMER, M. R. Creating Shared Value. How to reinvent capitalism and unleash a wave of innovation and growth. Harvard Business Review, 2011.

PROARGEX. Estudio de mercado de productos orgánicos en Brasil. Argentina, 2010. 80 p. Disponível em: <http://www.proargex.gov.ar/index.php/servicios/info-de-mercado/26estudios-y-perfiles-de-mercado/176-estudio-de-mercado-de-productos-organicos-en-brasil > Acesso em: 5 de jun. 2013.

PROGRAMA DAS NAÇÕES UNIDAS PARA O MEIO AMBIENTE (PNUMA). Oficina Regional para América Latina y el Caribe. Disponível em: 〈http://www.pnuma.org/>. Acesso em: 17 de jun, 2013.

RABELLO, T. Um mapa parcial da agricultura orgânica no País, mas com números confiáveis. Brasil, 1 jun. 2012. Disponível em: $<$ http://www.portalorganico.com.br/noticia/61/um_mapa_parcial_da_agricultura_organica_no _pais_mas_com_numeros_confiaveis>. Acesso em: 12 jun.2013.

RAMSAY, J. The real meaning of value in trading relationships. International Journal of Operations \& Production Management, v. 25, Iss: 6. 6, p. 549-565, 2005.

REBELATTO, L. C. Regulamentação da Agricultura Orgânica no Brasil: Caminhos, "descaminhos" e sua contribuição na construção do sistema de comércio ético e solidário. Florianópolis/SC, 2005.

RESEARCH INSTITUTE OF ORGANIC AGRICULTURE (FIBL); INTERNACIONAL FEDERATION OF ORGANIC AGRICULTURE MOVEMENTSI (FOAM). Organic world. Global organic farming statistics and news. Data tables FiBL-IFOAM. 2014b. Disponível em: <http://www.organic-world.net/statistics-fao.html> Acesso em: 23 de abr. 2014.

The world of organic agriculture. Statistic and emerging trends 2014. p. 308.

2014a.

REVISTA DA ASSOCIAÇÃO BRASILEIRA DE SUPERMERCADOS (ABRAS). Crescimento sustentável. Os números do Brasil e do Mundo. SuperHiper Panorama 2011, 5. ed. 2011. São Paulo.

RIBEIRO, J. F.; WALTER, B. M. T. Tipos de vegetação do bioma cerrado. Agencia de informação Embrapa, Bioma Cerrado. Ministério de Agricultura, Pecuária e Abastecimento. 
2007.

Disponível

em:

$<$

http://www.agencia.cnptia.embrapa.br/Agencia16/AG01/arvore/AG01_23 911200585232.ht

ml > Acesso em: 26 de agosto. 2014

RINDFLEISCH, A.; HEIDE, J. B. Transaction cost analysis: past, present, and future applications. Published by: American Marketing Association. Journal of Marketing, v. 61, n. 4, p. 30-54, Oct. 1997.

SAMBUICHI, R. H. R. et. al. Compras publicas sustentáveis e agricultura familiar: a experiência do programa de aquisição de alimentos (PAA) e do programa nacional de alimentação escolar (PNAE). In: SAMBUICHI, R. H. R. et. al. Políticas agroambientais e sustentabilidade: desafios, oportunidades e lições aprendidas. Brasília: Ipea, 2014. cap. 3 , p. $75-104$.

SARANDÓN, S.J.; FLORES, C.C. Evaluación de la sustentabilidad en agroecosistemas: una propuesta metodológica. Agroecología, v 4, p.19-28, 2009.

SERVIÇO BRASILEIRO DE APOIO ÀS MICRO E PEQUENAS EMPRESAS (SEBRAE). Estudos de inteligência de mercado. Perfil de mercado. Informe do serviço brasileiro de apoio às micro e pequenas empresas. Brasil, 2010.

SILVEIRA, D. T.; CÓRDOVA, F. P. A pesquisa científica. In: GERHARDT, T. E; SILVEIRA, D. T. Métodos de pesquisa. Universidade Federal de Rio Grande do Sul. 2009. unidade 2 , p. $31-42$.

SILVEIRA, G. J. C.; SOUSA, R. Paradigms of choice in manufacturing strategy: exploring performance relationships off it, best practices, and capability-based approaches. International Journal of Operations and Production Management. v. 30, n. 12, p. 12191245. 2010.

SIMON, H. El comportamiento administrativo. 1957

STANK, T.P.; DITTMANN, J.P.; AUTRY, C.W. The new supply chain agenda: a synopsis e directions for future research. International Journal of Physical Distribution \& Logistics Management. Department of Marketing and Logistics, University of Tennessee, Knoxville, Tennessee, USA. v. 41, $\mathrm{n}^{\circ}$ 10, p. 940-955. 2011.

TERPEND, R. et al. Buyer-Supplier Relationships: Derived Value over Two Decades. Journal of Supply Chain Management, v. 44, n² 2, p. 28-55. 2008. 
TIERRAMÉRICA. Legislação e direito ambiental. 2001. Disponível em: <http://www.tierramerica.net/2003/0526/pconectate.shtml>. Acesso em: 2 jun.2013.

VILCKAS, M.; NANTES, J. F. D. Agregação de valor: uma alternativa para a expansão do mercado de alimentos orgânicos. Organizações Rurais e Agroindustriais. Lavras, v. 9, n. 1, p. 26-37, 2007.

VILELA, N. J. et al. Perfil dos consumidores de produtos orgânicos no Distrito Federal. Comunicado técnico. Brasília, DF: Embrapa. ISSN 1414-9850. dez. 2006

WILLIAMSON, O. E. The economics of organization: the transaction cost approach. American journal of sociology, n. 3, v. 87, f. 548 - 577, 1981

Markets and hierarchies: analysis and antitrust implications. The economic journal, n. 343, v. 86. f. $619-621.1976$

Strategizing, economizing and economic organization. Strategic management journal, v. 12, f. 75 - 94, 1991 


\section{APÊNDICES}

\section{APÊNDICE A - Avaliação da transição agroecológica em propriedades rurais.}

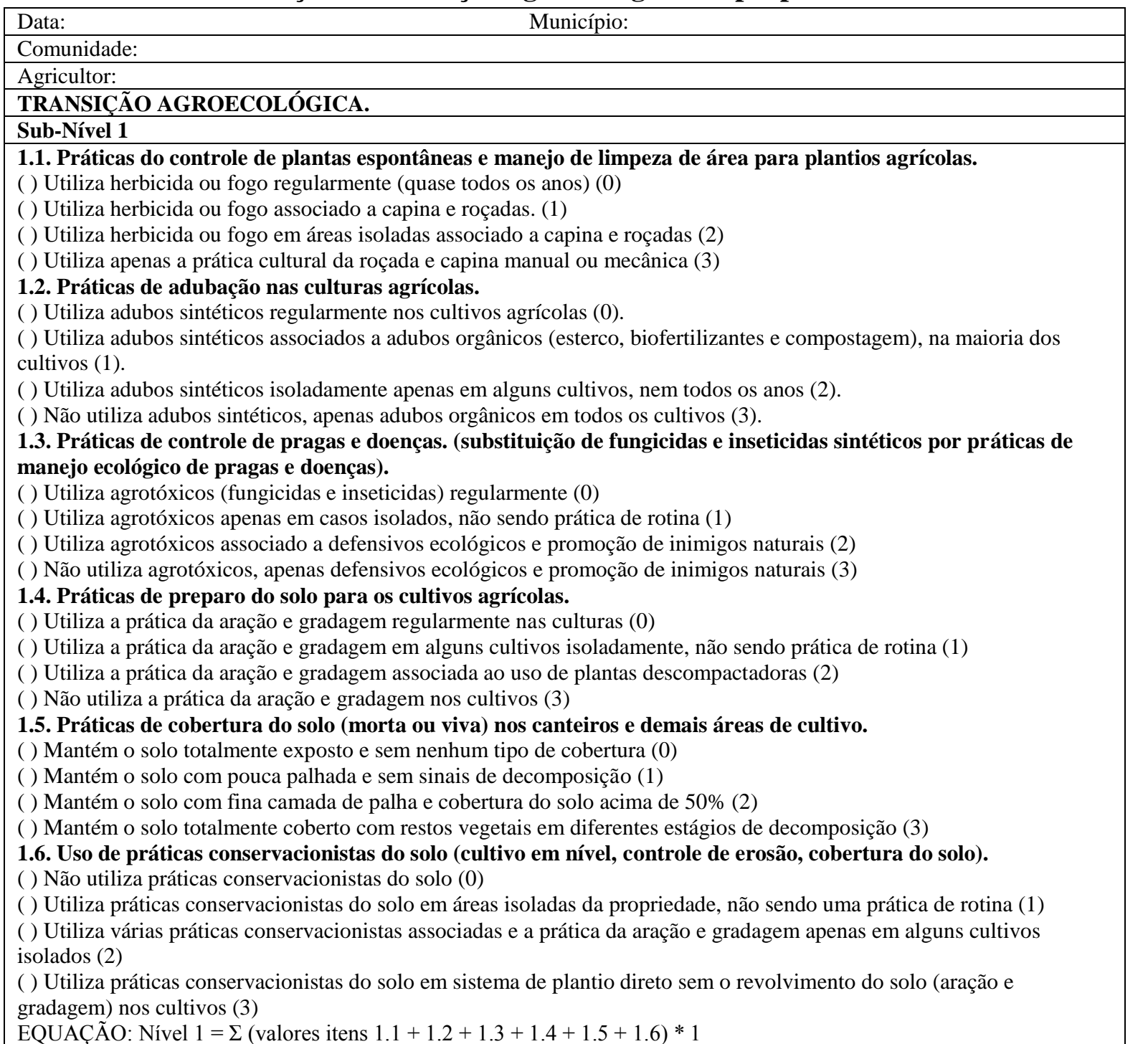

\section{Sub-Nível 2}

2.1. Práticas de utilização de insumos de base ecológica: esterco, urina de vaca, biofertilizante, compostagem, adubação verde com espécies leguminosas, calda bordalesa e outros.

( ) Não utiliza insumos de base ecológica (0)

( ) Utiliza um tipo de insumo de base ecológica (1)

( ) Utiliza entre dois até três tipos de insumos de base ecológica (2)

( ) Utiliza mais de três tipos de insumos de base ecológica (3)

2.2. Práticas de rotação de culturas nos cultivos agrícolas.

( ) Não utiliza rotação de culturas (0)

( ) Utiliza rotação de culturas em algumas áreas e culturas (ou glebas), não sendo a maioria (1)

( ) Utiliza rotação de culturas na maioria das áreas (ou glebas) e culturas (2)

( ) Utiliza rotação de culturas em todas as áreas (ou glebas) da propriedade (3)

2.3. Práticas de uso da biodiversidade funcional e de componentes da paisagem no manejo produtivo das culturas agrícolas.

( ) Não mantém cercas vivas ou cordões vegetados (0)

( ) Apenas a cultura principal é circundada por cercas vivas ou cordões vegetados (1)

( ) Mais de uma das culturas agrícolas são cercadas por cercas vivas ou cordões vegetados apenas com função de barreira vegetal (2).

( ) Todas as culturas agrícolas são cercadas por cercas vivas ou cordões vegetados, com utilização produtiva e ecológica (quebra-vento, melífera, forrageira e outras) (3) 
2.4. Adoção de técnicas de controle biológico de pragas e doenças

( ) Não utiliza técnicas de controle biológico de pragas e doenças (0)

( ) Utiliza uma técnica ou agente de controle biológico para uma cultura específica ou área isolada (1)

( ) Utiliza mais de uma técnica ou agentes de controle biológico, porém apenas em culturas isoladas (2)

( ) Utiliza mais de uma técnica ou agentes de controle biológico em diversas culturas, sendo uma prática de rotina na propriedade (3)

2.5. Eficiência no uso da energia e insumos baseados na reciclagem de nutrientes.

( ) Utiliza apenas insumos externos à propriedade rural (0).

( ) Utiliza na maioria dos casos insumos externos e, em casos isolados, utiliza insumos internos baseados na reciclagem de nutrientes (ex: adubação verde, esterco, silagem, compostagem, banco de forrageiras, sistemas agroflorestais ou silvipastoris) (1).

( ) Utiliza insumos externos associados a insumos internos baseados na reciclagem de nutrientes (ex: adubação verde, esterco, silagem, compostagem, banco de forrageiras, sistemas agroflorestais ou silvipastoris) (2).

( ) Utiliza apenas insumos internos baseados na reciclagem de nutrientes (ex: adubação verde, esterco, silagem, compostagem, banco de forrageiras, sistemas agroflorestais ou silvipastoris) (3)

VALOR TOTAL NÍVEL $2=\Sigma$ (valores itens $2.1+2.2+2.3+2.4+2.5) * 2$

\section{Sub-Nível 3}

3.1. Produção de sementes próprias (ou mudas)

( ) Utiliza sementes transgênicas. (0).

( ) Não produz nenhum tipo de sementes próprias ou crioulas. (1)

( ) Produz até três tipos de sementes próprias para as culturas principais ou comerciais (ex. milho, arroz, feijão, hortaliças, frutíferas). (2)

( ) Produz mais de três tipos de sementes na propriedade para as culturas principais ou comerciais (ex. milho, arroz, feijão, hortaliças, frutíferas e outras). (3)

3.2. Adoção de policultivos agrícolas e Sistemas Agroflorestais.

( ) Utiliza apenas a prática da monocultura. (0)

( ) Utiliza monocultura na maioria dos cultivos e policultivos em algumas culturas ou áreas (glebas) isoladas. (1)

( ) Utiliza a prática de policultivos ou sistemas agroflorestais na maioria dos cultivos, mas ainda utiliza a prática da monocultura em algumas culturas em áreas (glebas) isoladas. (2)

( ) Utiliza apenas a prática de policultivos ou sistemas agroflorestais. (3)

3.3. Manejo da paisagem - uso da biodiversidade funcional do agroecossistema através de espécies vegetais ou animais no sistema de produção agrícola (cercas vivas, plantas atrativas, plantas repelentes, organismos de controle biológico, entre outras).

( ) Desconhece e não utiliza a prática de uso da biodiversidade funcional. (0)

( ) Utiliza a prática de uso da biodiversidade funcional apenas em casos isolados de manejo de pragas e doenças ou por necessidade das normas de produção orgânica. (1)

( ) Utiliza a prática de uso da biodiversidade funcional nos cultivos principais. (2)

( ) Utiliza a prática do aumento da biodiversidade funcional em todos os cultivos e áreas (glebas) da propriedade como estratégia de manejo, redesenho e equilíbrio do agroecossistema. (3)

3.4. Utilização de áreas de preservação permanente (APP) e reserva legal (RL) como parte do sistema de produção agrícola da propriedade, de acordo com a legislação ambiental.

( ) Apresenta as áreas de APP e de RL degradadas e sem a vegetação nativa predominante. (0)

( ) Apresenta as áreas de APP e de RL com a vegetação nativa predominante em processo de recuperação e regeneração. (1)

( ) Apresenta as áreas de APP e de RL com a vegetação nativa predominante, entretanto não as utiliza no sistema produtivo da propriedade. (2)

( ) Apresenta as áreas de APP e de RL com a vegetação nativa predominante, com utilização no sistema produtivo da propriedade. (3)

3.5. Filiação à entidades associativas ou cooperativas.

( ) Não é filiado a entidades cooperativas ou associativas. (0)

( ) É filiado na associação ou cooperativa local da comunidade. (1)

( ) É filiado na associação local da comunidade e em cooperativas locais ou regionais. (2)

( ) É filiado na associação local da comunidade e em cooperativas locais ou regionais como representante e com participação ativa. (3)

EQUAÇÃ̂: Nível $3=\Sigma$ (valores itens $3.1+3.2+3.3+3.4+3.5) * 2$

Fonte: adaptado de FEISTAUER (2012). 


\section{APÊNDICE B - Legislação Ambiental}

Área da propriedade: ha. Coordenada Geográfica: Lat:

Long:

\section{Caracterização da propriedade:}

Área da RL (aprox): $\mathrm{N}^{\circ}$ Córregos que cortam a propriedade: Larguras dos córregos:

Área APP (aprox): N. ${ }^{\circ}$ nascentes Nascentes vegetadas ( ) sim ( ) não

Produtor orgânico: ( ) sim ( ) não / até 5 anos ( ) mais de 5 anos ( ) convencional ( )

É produtor orgânico certificado? ( ) sim ( ) não Há quanto tempo? ( ) anos Tipo de Certificação:

Utiliza princípios, técnicas ou insumos de base ecológica em sua propriedade? ( ) sim ( ) não Há quanto tempo? ( ) anos. Recebe assistência técnica para isso? ( ) sim ( ) não Acha suficiente? ( ) sim ( ) não

\section{Perguntas}

Possui Licenciamento Ambiental (LAU) da propriedade? ( ) sim ( ) não

Possui a RL averbada? ( ) sim ( ) não Já tentou realizar a averbação? ( ) sim ( ) não

Qual o percentual de RL necessário para a sua propriedade? ( ) $20 \%$ ( ) $35 \%$ ( ) $50 \%$ ( ) $80 \%$ ( ) outra ( ) não sabe

Sabe qual a área de mata na APP localizada em nascente? ( ) 10m ( ) 30m ( ) 50m ( ) outra: ( ) não sabe

Sabe qual a área de mata na APP localizada nas margens do(s) córrego(s) localizadas em sua propriedade? Largura do córrego: ( ) $10 \mathrm{~m} \mathrm{(} \mathrm{)} \mathrm{30m} \mathrm{(} \mathrm{)} \mathrm{50m} \mathrm{(} \mathrm{)} \mathrm{outra:}$

( ) não sabe

Fonte: adaptado de FEISTAUER (2012). 


\section{APÊNDICE C- Criação de valor}

\section{A visão do Mercado de produtos orgânicos (Cliente).}

Objetivos: descobrir os mecanismos que criam valor através dos relacionamentos colaborativos entre o mercado de produtos orgânicos e os produtores (fornecedores).

1.1 Quais são os principais produtos comercializados (Comprados) por vocês?

1.2 Qual é o produto mais (Comprado) comercializado, a sua quantidade e frequência de comercialização?

\begin{tabular}{|l|l|l|l|l|l|l|}
\hline \multirow{2}{*}{ Produto } & \multirow{2}{*}{ Kg } & \multirow{2}{*}{ Maço } & \multicolumn{4}{|c|}{ FREQÜÊNCIA } \\
\cline { 4 - 7 } & & Diário & Semanal & Mensal & Outra/qual? \\
\hline & & & & & & \\
\hline
\end{tabular}

1.3 É exigido algum tipo de certificação da sua parte ao provedor no momento de realizar a negociação dos produtos orgânicos? Que tipo de certificação? Por quê?

\begin{tabular}{|l|c|}
\hline \multicolumn{1}{|c|}{ MECANISMO DE CERTIFICAÇÃO } & (X) \\
\hline Controle social a partir de Organização de Controle Social (OCS) & \\
\hline Sistemas participativos da avaliação da conformidade orgânica (OPAC) & \\
\hline Certificação por auditoria & \\
\hline Outro. Qual: & \\
\hline
\end{tabular}

1.4 Quanto tempo tem a relação comercial com o fornecedor (es) X?

1.5 Quem iniciou a relação comercial com o fornecedor (es) X foi o mercado ou foi o mesmo fornecedor? Como aconteceu?

1.6 Durante o tempo de relação comercial com o fornecedor (es) X, tem sido otimizados os resultados mediante o aproveitamento dos recursos e capacidades de ambas as partes? Descreva.

1.7 Na relação comercial com seu fornecedor existe algum tipo de confiança no momento da negociação dos produtos orgânicos? Descreva.

1.8 Existe algum tipo de aprendizagem (capacidade ou habilidade) novo importante obtido por meio do relacionamento comercial? Descreva.

1.9 Em algum momento foram feitas capacitações de forma conjunta ou de uma das partes para a outra? De que tipo? Descreva.

1.10 Durante o tempo de relacionamento comercial, foi obtida informação nova importante que ajudara ao melhoramento conjunto ou de uma das partes? De que tipo? Descreva.

1.11 São mantidos os mesmos objetivos de melhora continua entre as duas partes? Descreva.

1.12 As decisões que afetam o relacionamento comercial são tomadas de forma bilateral ou unilateral? Explique.

1.13 Numa relação comercial deve existir um acordo contratual para o controle do acordado entre as partes. Concorda ou Discorda? Por quê?

$1.14 \mathrm{O}$ relacionamento comercial com seu fornecedor (es) é mantido mediante contratos? Quais são as caraterísticas desses contratos?

1.15 Como acontece o controle da fixação dos preços dos produtos? 
1.16 Durante o tempo da relação comercial com o fornecedor (es) X, foi obtido algum tipo de ativo (equipamento, processo, serviço, maquinaria, etc.)? Como sucedeu?

1.17 Foi acumulado conhecimento durante o desenvolvimento do relacionamento comercial? De que tipo?

1.18 Foi adquirida uma reputação? Pode descrevê-la?

1.19 Formam adquiridas novas capacidades ou competências? Quais?

1.20 Porque escolheram se-relacionar comercialmente com o produtor (es) X?

1.21 Comparado com o inicio, como é o relacionamento comercial hoje? Descreva.

1.22 Quais são as vantagens de se manter o relacionamento comercial com seu fornecedor (es)?

1.23 O relacionamento com o fornecedor $\mathrm{X}$ contribui com o objetivo de obter vantagens sobre os concorrentes? Como ocorre?

1.24 A certificação orgânica e a aderência às normas ambientais por parte do seu fornecedor (es) contribuem à diferenciação frente aos outros fornecedores não certificados? Como ocorre?

1.25 Existe alguma vantagem adicional de contar com um provedor que cumpra com a normativa orgânica e/ou obedeça à normativa ambiental?

\section{A visão dos fornecedores (Produtores).}

Objetivos: descobrir os mecanismos que criam valor através dos relacionamentos colaborativos entre os produtores (fornecedores) e o mercado de produtos orgânicos.

2.1 Quais são os principais produtos comercializados (Vendidos) por vocês?

2.2 Qual é o produto mais comercializado (Vendido), a sua quantidade e frequência de comercialização?

\begin{tabular}{|l|l|l|l|l|l|l|}
\hline \multirow{2}{*}{ Produto } & \multirow{2}{*}{ Kg } & \multirow{2}{*}{ Maço } & \multicolumn{4}{|c|}{ FREQÜÊNCIA } \\
\cline { 5 - 7 } & & & Diário & Semanal & Mensal & Outra/qual? \\
\hline
\end{tabular}

2.3 A propriedade é certificada como de produção orgânica? Sim ( ) De que tipo? (__ Há quanto tempo? ( ) anos Não ( ) Não aplica ( ). Por quê?

2.4 É exigido algum tipo de certificação por parte do comprador no momento de realizar a negociação dos produtos orgânicos? Que tipo de certificação? Por quê?

\begin{tabular}{|l|c|}
\hline \multicolumn{1}{|c|}{ MECANISMO DE CERTIFICAÇÃ̃ } & $(\mathrm{X})$ \\
\hline Controle social a partir de Organização de Controle Social (OCS) & \\
\hline Sistemas participativos da avaliação da conformidade orgânica (OPAC) & \\
\hline Certificação por auditoria & \\
\hline Outro. Qual: & \\
\hline
\end{tabular}

2.5 Quanto tempo tem a relação comercial com o comprador (es) X?

2.6 Quem iniciou a relação comercial com o comprador (es)? Como aconteceu?

2.7 Durante o tempo de relação comercial com o comprador (es) X, tem sido otimizados os resultados mediante o aproveitamento dos recursos e capacidades de ambas as partes? Descreva.

2.8 Na relação comercial com seu comprador (es) $\mathrm{X}$ existe algum tipo de confiança no momento da negociação dos produtos orgânicos? Descreva. 
2.9 Existe algum tipo de aprendizagem (capacidade ou habilidade) novo importante obtido por meio do relacionamento comercial? Descreva.

2.10 Em algum momento foram feitas capacitações de forma conjunta ou de uma das partes para a outra? De que tipo? Descreva.

2.11 Durante o tempo de relacionamento comercial, foi obtida informação nova importante que ajudara ao melhoramento conjunto ou de uma das partes? De que tipo? Descreva.

2.12 São mantidos os mesmos objetivos de melhora continua entre as duas partes? Descreva.

2.13 As decisões que afetam o relacionamento comercial são tomadas de forma bilateral ou unilateral? Explique.

2.14 Numa relação comercial deve existir um acordo contratual para o controle do acordado entre as partes. Concorda ou Discorda? Por quê?

$2.15 \mathrm{O}$ relacionamento comercial com seu fornecedor (es) é mantido mediante contratos? Quais são as caraterísticas desses contratos?

2.16 Como acontece o controle da fixação dos preços dos produtos?

2.17 Durante o tempo da relação comercial com o comprador (es) X, foi obtido algum tipo de ativo (equipamento, processo, serviço, maquinaria, etc.)? Como sucedeu?

2.18 Foi acumulado conhecimento durante o desenvolvimento do relacionamento comercial? De que tipo?

2.19 Foi adquirida uma reputação? Pode descrevê-la?

2.20 Formam adquiridas novas capacidades ou competências? Quais?

2.21 Porque escolheram se-relacionar comercialmente com o comprador (es) X?

2.22 Comparado com o inicio, como é o relacionamento comercial hoje? Descreva.

2.23 Quais são as vantagens de se manter o relacionamento comercial com seu comprador (es)?

$2.24 \mathrm{O}$ relacionamento com o comprador (es) $\mathrm{X}$ contribui com o objetivo de obter vantagens sobre os concorrentes? Como ocorre?

2.25 A certificação orgânica e a aderência às normas ambientais por sua parte contribuem à diferenciação frente aos outros fornecedores não certificados? Como ocorre?

2.26 Existe alguma vantagem adicional de cumprir com a normativa orgânica e/ou obedeça à normativa ambiental? 